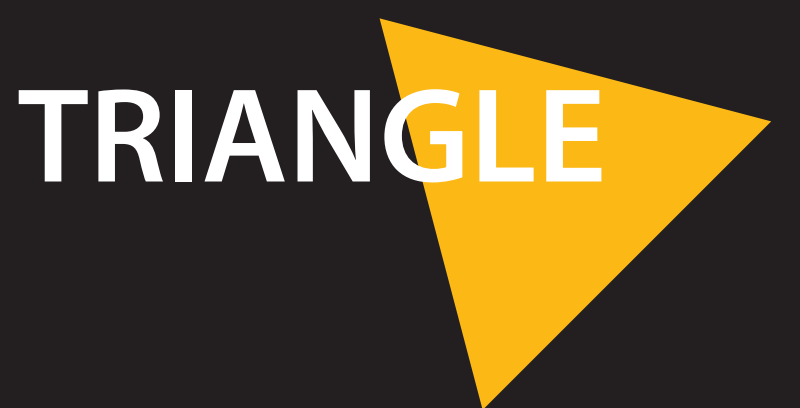

LLENGUATGE, LITERATURA, COMPUTACIÓ

LANGUAGE, LITERATURE, COMPUTATION

\title{
3
}

Alejandra Pizarnik:

vida, obra y principales símbolos poéticos

María Isabel Calle 


\section{TRIANGLE 3}

March 2010

\section{Alejandra Pizarnik: \\ vida, obra y principales motivos poéticos}

María Isabel Calle

LLENGUATGE, LITERATURA, COMPUTACIÓ

LANGUAGE, LITERATURE, COMPUTATION

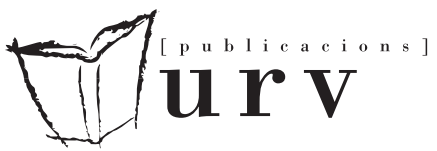

Tarragona, 2011 
Revista TRIANGLE

President: Antonio Garcia Español

Consell editorial: M. Angeles Caamaño, Natalia Català,

M. Dolores Jiménez López, M. José Rodríguez Campillo.

Gemma Bel-Enguix per la Sèrie Linguistics, Biology and Computation,

i Esther Forgas per la Sèrie Español Lengua Extranjera.

\section{Edita: Publicacions URV}

ISSN: 2013-939X

ISBN: 978-84-693-6954-4

DL: T-1492-2010

Per a més informació de la revista consulteu la pàgina http://revista-triangle.blogspot.com/

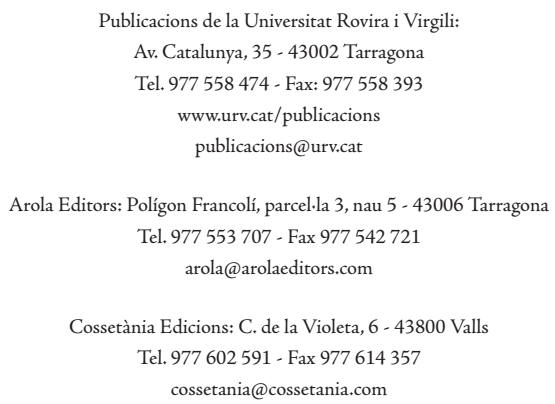




\title{
Alejandra PizarniK: VIDA, OBRA Y PRINCIPALES SÍMBOLOS POÉTICOS
}

\author{
María Isabel Calle \\ Professora Associada \\ Departament de Filologies Romàniques \\ Universitat Rovira i Virgili \\ Avda. Catalunya, 35 \\ 43005 Tarragona, SPAIN
}

email: mariaisabel.calle@urv.cat 


\section{Índice general}

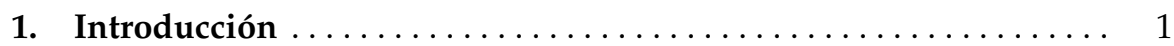

2. Aproximación a la vida y a la obra de Alejandra Pizarnik ...... 3

1. Primeros pasos: de la adolescencia al viaje a París (1936-1959) . 3

2. El sueño parisino $(1959-1964) \ldots \ldots \ldots \ldots \ldots \ldots \ldots \ldots \ldots \ldots \ldots \ldots$

3. Regreso a Buenos Aires (1964-1972) ................ 20

3. Símbolos de la obra poética de Alejandra Pizarnik ......... 33

1. El universo celeste: astros y bóvedas ................. 33

2. Naturaleza ensoñadora y destructiva $\ldots \ldots \ldots \ldots \ldots \ldots \ldots . \ldots \ldots$

3. Animales en la noche.......................... 60

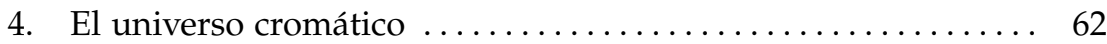

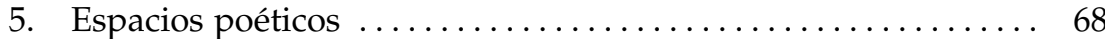

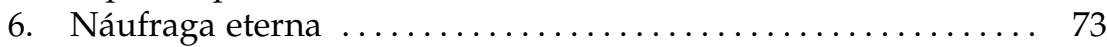

7. Monstruos y seres mitológicos .................... 79

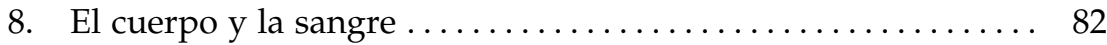

9. Reflejos del espejo.......................... 87

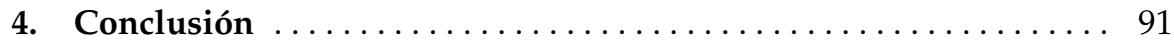

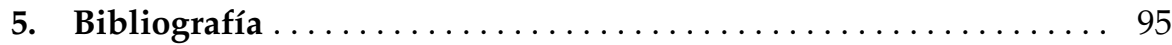

1. Obras de Alejandra Pizarnik .................... 95

1.1. Primeras ediciones de las obras de A. Pizarnik ........ 95

1.2. Ediciones de la obra de A. Pizarnik .............. 95

2. Libros y artículos sobre Alejandra Pizarnik .............. 96 
VIII Índice general

2.1. Bibliografía electrónica sobre Alejandra Pizarnik . . . . . . 99

6. Referencias Bibliográficas $\ldots \ldots \ldots \ldots \ldots \ldots \ldots \ldots \ldots \ldots \ldots \ldots \ldots \ldots$ 


\section{Introducción}

El presente trabajo se centra en la producción literaria de Alejandra Pizarnik, de la que se analizará, a partir de los textos poéticos, la evolución de su lenguaje y los símbolos que se reiteran para crear un universo a modo de microcosmía o "jardín cerrado". Atender casi de forma exclusiva al análisis de los poemas de Alejandra Pizarnik permite conocer detalladamente las claves de su evolución poética, una de las cuales es el dualismo o desencuentro, que articula los dos aspectos fundamentales de su obra: el lenguaje y los símbolos.

Alejandra Pizarnik nace en Buenos Aires en 1936 en el seno de una familia de emigrantes judíos que habían huido de la amenaza nazi. En Buenos Aires inicia sus estudios en la Facultad de Filosofía y Letras, y asiste también a las clases del pintor Juan Batlle Planas. Es éste, junto con Juan-Jacobo Bajarlía, quien la introduce en el mundo de las letras argentinas. Durante estos primeros años publica en 1955 La tierra más ajena, en 1956 La última inocencia y en 1958 Las aventuras perdidas.

Tras su primera etapa porteña, en 1960 realiza su primer viaje a París, ciudad en la que se consolida como poeta. Allí se dedica por completo a la creación literaria y adquiere su madurez poética. Durante este periodo conoce a muchos de los escritores y poetas que ejercerán una gran influencia a lo largo de su vida: André Pieyre de Mandiargues, Octavio Paz y Julio Cortázar. Tras su vuelta a Argentina publicará en 1962 Árbol de Diana y, tres años más tarde, Los trabajos y las noches. En 1968 se publica Extracción de la piedra de locura y, posteriormente, obtiene una beca Guggenheim. Regresa de nuevo a París en 1969, aunque este reencuentro le provoca una gran insatisfacción. En 1971 se publica El infierno musical y La condesa sangrienta, 
primer libro en prosa. Al fin, en 1972, se suicida con una sobredosis de seconal.

Para profundizar en el hermetismo poético pizarnikiano, en el siguiente apartado se han tratado de clasificar los diferentes campos semánticos de algunos de los símbolos más significativos de su obra. Desde el "jardín" hasta el "espejo" se ha intentado configurar, más que la significación del propio símbolo, su evolución a través de la poética pizarnikiana. En algunas ocasiones, el símbolo adquiere incluso el valor de personaje a lo largo del recorrido poético. Alejandra Pizarnik reitera muchos de sus símbolos creando una relación indestructible entre todas sus obras poéticas y provocando la evolución del símbolo como si de un personaje poético propio se tratara, puesto que, en muchas ocasiones, la psicología de estos personajes simbólicos permuta y evoluciona a medida que la poeta avanza en su obra.

Por esta razón, la poesía pizarnikiana adquiere un valor humano capaz de ahondar en los sentimientos más oscuros y procaces de la vida a través de un lenguaje simbólico difícil de descifrar en su individualidad pero fecundo, pingüe e indispensable en su totalidad y multiplicidad. 


\section{Aproximación a la vida y a la obra de Alejandra Pizarnik}

\section{Primeros pasos: de la adolescencia al viaje a París (1936-1959)}

Dicen que la muerte (poética o no) define el camino vital de Alejandra Pizarnik. Tal vez fuera por el desarraigo que conlleva la huida a un país que ni tan siquiera supo pronunciar su apellido (Pozharnik), o puede que fuera por el asesinato de la mayoría de los miembros de su familia en un holocausto que acechaba a toda Europa.

En cualquier caso, Flora Alejandra Pizarnik nace en Avellaneda, una localidad cercana a la gran capital, un 29 de abril de 1936 en una casa de dos plantas por la que ya correteaba su hermana Myriam. Los padres, Elías Pozharnik y Rejzla Bromiker en Rovne (Rusia) y Elías Pizarnik y Rosa Bromiker en Avellaneda (Argentina), instituían un nuevo régimen familiar en una comunidad judía capaz de soslayar los problemas culturales, fundiéndose con una cultura y un idioma extraños pero acogedores. Tras un largo camino desde Rovne y una estancia de varios meses en París, donde vivía su tío paterno, lograron arribar huyendo de la marea nazi a un puerto argentino de calma y aceptación donde anclaron un nuevo buque familiar en el que intentarían navegar a lo largo de su existencia.

El gusto por la música clásica inculcado por el padre y tal vez aquella tía rusa que se dedicaba a la literatura hicieron de la infancia un nuevo espacio de notas y letras que llevaría a la autora a pasear junto a Sartre y Edith Piaf a lo largo de la adolescencia. Una economía holgada, gracias al negocio de joyería de su padre, permitió que la educación de A. Pizarnik absorbiera los 
conocimientos de dos escuelas: la n. ${ }^{\circ} 7$ de Avellaneda y la Zalman Reizien Schule, escuela progresista en la que aprendía el iddish y la religión e historia judía. Pero no todo fue un camino de rosas: sus padres pululaban por entonces en una nube de terror causada por las fechorías abominables de un nazismo que arrasaba Europa occidental a un ritmo estremecedor y que les provocaba una tristeza difícil de ocultar a una mente tan despierta como la suya. Por otro lado, las eternas comparaciones con su hermana, más rubia, más delgada, menos enfermiza y más perfecta que ella, ahondaban en el cuerpo gordito y gracioso de A. Pizarnik completado por una leve tartamudez y un asma incipiente.

Con la edad, las extravagancias se acentuaron aún más; así, para A. Pizarnik, la adolescencia confirmó el antagonismo que sobrevolaba entre sus suéteres de hombre y los vestidos de tul y seda que tanto fascinaban a su madre. Era aquella chica divertida, blasfema, que fumaba sin cesar escondida en su cueva, la cueva que tanto odiaban las madres de sus amigas. Representaba todo aquello que no debía ser una señorita, aunque escondía tras de sí un existencialismo sartriano ${ }^{1}$ capaz de hechizar a todas sus compañeras. No sólo propició la literatura entre su círculo escolar, sino que, ya en esta época, su cuarto, angosto y con olor a cigarrillo, albergaba en sus paredes vaticinios de lo que sería su vida: la poesía.

La Buma (otra de sus Alejandras) ${ }^{2}$ a la que sus padres apelaban empezaba su metamorfosis hacia una Alejandra fuera de contexto, incomprendida intelectualmente, a pesar de los esfuerzos de su padre y de algunas de sus amigas. Sus relaciones fallidas con el otro sexo, la preocupación por una estética que siempre acuchilló su ego (su eterno acné, el pequeño sobrepeso) y las frecuentes anfetaminas tan de moda en la época para alcanzar la

1“Tampoco debe descartarse la influencia del movimiento existencialista que, a partir de las traducciones de las obras de Sartre, cobró inusitada divulgación en nuestros círculos literarios iniciados ya en esa corriente a través de Unamuno, Ortega y Gasset y de algunos filósofos alemanes" (N. Salvador, La nueva poesía argentina, Buenos Aires, Nuevos Esquemas, 1969, 23).

2 "Buma para la madre y el padre [...].

Flora en la Escuela Normal Mixta de Avellaneda [... ].

Blímele para los maestros de la Zalman Reizien Schule [... ].

Alejandra al llegar la adolescencia, como contraseña para asumir la propia vocación $[\ldots]$.

Sasha al final, como el nombre más secreto [...].

Buma, Flora, Blímele, Alejandra, Sasha: cinco nombres para un idéntico destino puntual" (C. Piña, op. cit., 1999, 15). 
delgadez empezaron a incubar las excentricidades y los lamentos de una Alejandra ya universitaria. Por esa época la muerte empezaba a ser la principal preocupación: qué será eso de morir, qué habrá más allá del momento en que la guadaña corte el hilo de la vida tejido por las parcas. Desconcertaba a quien se acercaba a ella.

Mientras renacía la política bonaerense, Alejandra, ya en quinto curso, había forjado su vocación de escritora, una aptitud que la llevaría a estudiar en las aulas de la Facultad de Filosofía y, más tarde, en las de la Facultad de Periodismo. Durante su estancia universitaria, su vida será un ajetreo indecoroso, un ir y venir de facultades, cafés, tertulias y fiestas, actos sociales a los que Alejandra asistirá asiduamente gracias a su carácter rebelde, extravagante y provocativo, que atraía todas las miradas y comentarios. Será Juan Jacobo Bajarlía quien la introduzca en el caótico mundo literario de entonces. Bajarlía había conseguido la cátedra de Literatura Moderna y la condujo por los caminos de Proust, Gide, Claudel, Kierkegaard, Leopardi, Joyce y, por supuesto, por los derroteros surrealistas del París de principio de siglo. Ella congenió muy bien con todas esas lecturas, sobre todo con Proust, con el que compartió el círculo de pasiones y sentimientos que más tarde se adueñarían de la primera etapa poética; y también con Claudel, con quien se identificaría debido a su marca de extranjería. ${ }^{3}$

Pero los problemas que habían empezado a sembrarse en la adolescencia empiezan a germinar y a acentuarse en la etapa universitaria. Por este motivo, Alejandra inicia su conocida terapia con el analista León Ostrov, terapia y amistad que se alargará durante varios años. Pizarnik brillaba por su inteligencia y sociabilidad, pero esta última se la debía sobre todo a León, que consiguió acabar con la tartamudez y la consecuente timidez, para lograr una nueva Alejandra de dicción excepcional, fascinante, excéntrica y con un toque exótico debido a su acento extranjero. Así, vuelve a moverse en una dicotomía; no sólo la extranjería ${ }^{4}$ y el círculo familiar la hacen partícipe

${ }^{3}$ Este sentimiento de no pertenencia la acompañará a lo largo de toda su trayectoria vital y poética: “No quiero morir en este país. Padre, padre querido, no quiero morir en este país que -ahora lo sé- odiabas o temías. Del horror que te causaba, de la extranjeridad que te producía, solamente yo puedo dar testimonio. Y saberte para siempre, por siempre en esta tierra azarosa y basta, nunca podré consolarme y debo irme y morir fuera de este lugar al que no debiste venir, padre, ni yo debí regresar" (A. Pizarnik, Diarios, Barcelona, Lumen, 2005, 431).

4 “Soy Argentina! Argentum, i: plata. Mis ojos se aburren ante la evidencia. Pampa y caballito criollo. Literatura soporífera. una se acerca a un libro argentino. ¿Qué 
de dos mundos, sino que la nueva peregrinación por los parajes literarios bifurca su personalidad en dos Alejandras distintas: la apesadumbrada y acongojada Alejandra de los círculos literarios, tímida y silenciosa; y la jocosa y burlona, casi infantil, que provocaba la risa y la admiración entre sus amigas. Será esta infantilidad la que provoque el repudio de su primera obra, La tierra más ajena, ${ }^{5}$ de 1955 (tan infantil que la sufragó su padre). Firmada como Flora Alejandra Pizarnik, La tierra más ajena es su obra más miméticamente surrealista, en la que su condición de foránea (ajena) y de adolescente infanticida (ajena de nuevo) incitan a la elaboración de unos poemas bretonianos, libres y cargados de unas imágenes insólitas, todavía atentos a lo exterior, característica que irá desapareciendo a medida que el subjetivismo y la mirada interna se adueñen de su consciente aporético:

Simplemente no soy de este mundo... yo habito con frenesí la luna... No tengo miedo de morir; tengo miedo de esta tierra ajena, agresiva... no puedo pensar en cosas concretas; no me interesan... Yo no sé hablar como todos. Mis palabras son extrañas y vienen de lejos, de donde no es, de los encuentros con nadie... ¿qué haré cuando me sumerja en mis fantásticos sueños y no pueda ascender? Porque alguna vez va a tener que suceder.

Carta a León Ostrov, sin fecha, Correspondencia Pizarnik, Buenos Aires, Seix Barral, 1998, 53

Este gusto por el mundo exterior se extiende también a elementos cotidianos, algo que nos recuerda a Joyce ${ }^{6}$ y al detallismo rutinario de su Ulises: "[... ] además de todo lo que hemos dicho sobre Joyce, me cuesta avanzar

ocurre? Viles imitaciones francesas, modismos en bastardilla, fotografías pesadas del campo. [...] ¡Siento que mi lugar no está acá! (ni en ninguna parte quisiera decir)" (A. Pizarnik, op. cit., 2005, 27).

${ }^{5}$ Pizarnik, Alejandra: La tierra más ajena, Botella al Mar, Buenos Aires, 1955. Renegó de ella y no quiso incluirla en ninguna antología posterior: "Al fin, al fin te mandamos (Martha y yo) nuestra (tuya, suya, mía) antología. [...] Ahora bien, hay algunos detalles que quiero destacar y que atañen, por supuesto, a la antología: a) No figuran textos de mi primer libro -La tierra más ajena, Ediciones Botella al Mar, BS. AS. 1955-. La causa: reniego de ese libro" (A. Pizarnik, El deseo de la palabra, Barcelona, Ocnos, 1975, 34).

${ }^{6}$ “Comienzo a devenir adulta en mi relación con la literatura. Ser adulta quiere decir preferir Ulises al Retrato del artista adolescente, que quiere decir considerar en una ficción su inventiva, su desarrollo, su lenguaje; quiere decir no amar o admirar solamente por identificación o catarsis" (A. Pizarnik, op. cit., 2005, 191). 
en el Ulises. La falta de sensibilidad o emociones te dan ganas de dejarlo a un lado [... ]" (Carta a Juan Jacobo Bajarlía, 7-VIII-1955, Ivonne Bordelois, op. cit., 34). Tal vez sea por ello que le dedicará el poema "Dédalus Joyce".

Siguiendo con la fascinación por la duplicidad, Flora Alejandra recopila al final de su primera obra unos poemas amorosos bajo el título Un signo en tu sombra, poemas de sentimientos no correspondidos, algo ya habitual en la corriente alterna de su vida afectiva. Bajo ellos esconderá la timidez y la amargura febril que hay tras su cara alegre y llena de acné capaz de estremecer y derrumbar cualquier mirada disciplinada.

Al principio de su carrera, Alejandra Pizarnik se impregnó de una temprana influencia neorromántica y, más tarde, de los grupos vanguardistas a los que conoció directamente, aunque su postura nunca fue claramente surrealista ni tampoco estéticamente realista o socialmente comprometida ${ }^{7}$ (como sucedió con la corriente que se consolidará en los años 60 después del exilio de Perón); siempre se mantuvo al margen de la preocupaciones sociales y cotidianas. Busca una voz pura y diferente del panorama literario contemporáneo. ${ }^{8}$

${ }^{7}$ Alfredo Andrés enumera en el prólogo de su libro El 60 los tópicos comunes de los poetas de esta década y, a pesar de que la mayoría tienen cierta relación con una tendencia realista y social, incluye una tendencia hacia preocupaciones metafísicas en la que adscribe a A. Pizarnik:

La ondulación metafísica no es común en la poesía del 60 si consideramos masivamente a sus autores. Pese a esto, y quizás pueda parecer curioso (yo diría que más que curioso es sintomático), varios de los puntos más altos de la misma pueden encontrarse en poetas cuya proyección metafísica gravita en forma fundamental: Roberto Juarroz, Alejandra Pizarnik, Miguel Ángel Bustos, Omar Rubén Aracama.

\section{A. Andrés, El 60, Editores Dos, Buenos Aires, 1969, 21}

${ }^{8}$ Tanto Nélida Salvador como Alfredo Andrés, Horacio Salas, Stefan Baciu y Tomás Guido Lavalle en sus respectivas obras incluyen dentro de la llamada "Generación del 60" a una serie de poetas que no siguen los cánones sociales y realistas que predominan durante esos años, incluyendo a A. Pizarnik entre éstos. De mismo parecer es C. Piña en su obra Poesía de fin de siglo: "Erróneamente, se ha tendido a considerar la década del sesenta marcada de forma casi hegemónica por la poesía de de tono coloquial y orientada hacia las preocupaciones sociales que continúa el 'realismo humanista' de los cincuenta. [...] pero no puede olvidarse que, por un lado se desarrolla una línea de corte metafísico, cuyos representantes mayores en sus dos 
En 1955, A. Pizarnik también publica sus traducciones de las obras de Paul Eluard y de André Breton, absorbiendo para siempre la asimetría vital del movimiento parisino de entreguerras. Bajarlía introduce a A. Pizarnik en los altos círculos literarios, en los que conocerá a Oliverio Girondo, Aldo Pellegrini, Roberto Juaroz, Antonio Porchia, al que le dedicó uno de sus poemas de Los trabajos y las noches, ${ }^{9}$ y al pintor Juan Batlle, quien ejercerá una influencia esencial en la configuración espacial de su poesía posterior. No será su única influencia; J. Batlle representa la concepción singular de una figuración metafórica, pero también la pintura "naïf", ${ }^{10}$ floreciente en Argentina en ese entonces, junto a las pintoras Remedios Varo o Leonor Vassena, será admitida en el caballete pictórico-lingüístico de A. Pizarnik.

Ahora bien, una de las grandes amistades de este periodo será, sin duda, Antonio Requeni. Se conocieron en un reportaje para el diario La Opinión y a partir de ahí empezaron sus andanzas inseparables. Antonio no era sólo alguien con quien hablar, sino alguien con quien A. Pizarnik compartirá sus poemas, sus secretos, sus collages, sus papeles, sus útiles de papelería de coleccionista aficionada; incluso llegará a ser una de las pocas personas que su madre aceptará para ella, convirtiéndolo en el guardián custodio de su oveja descarriada; una madre que presidía un régimen tradicional difícil de congeniar con el carácter de A. Pizarnik, una huida que se veía acentuada

variantes son Alejandra Pizarnik y Roberto Juarroz, [... ]" (Piña, Poesía Argentina de Fin de Siglo, Buenos Aires, Vinciguerra, 1996, 48).

${ }^{9}$ LAS GRANDES PALABRAS a Antonio Porchia

aún no es ahora ahora es nunca

aún no es ahora ahora y siempre es nunca

10 “...] una de las hermanas Gómez Errázuriz, a las que probablemente conoció en el taller de Batlle Planas, tuvo una galería dedicada al arte naïf, El Taller, que fue un frecuentado centro de reunión de artistas y poetas. Esta pintura hecha por no pintores, que no excluía el esbozo de escenas visionarias como las que favorecían los surrealistas, era más apta a los esfuerzos de diletante, nunca muy persistentes, de Pizarnik, y le sumaba el lustre de la infancia" (Aira, Alejandra Pizarnik, Rosario, Bibl. El Escribiente, Beatriz Viterbo Editora, 1998, 11-12). 
por las exigencias y la rigidez de su padre, a pesar de apoyarla intelectualmente. Según Cristina Piña, ${ }^{11}$ este complejo de Edipo - o, mejor dicho, de Electra- será uno de los causantes de las fallidas relaciones amorosas ${ }^{12}$ con hombres jóvenes. Tal vez A. Pizarnik buscaba en el hombre maduro la comprensión, el afecto y la ternura que su padre no era capaz de darle. Esta falta de amor paternal la lleva a comportarse de modo infantil e inocente, despertando la protección de amigos, poetas y tertulianos.

Sea como fuere, se escabulle del círculo familiar, del orden social establecido, de todo aquello que comporta hablar por hablar sin decir absolutamente nada. Es por ello que empieza a buscar el silencio, ${ }^{13}$ un silencio musical capaz de conseguir la armonía del más bello adagio.

Como consecuencia, durante los años que transcurren entre 1956 y su viaje a París, A. Pizarnik emprende una carrera frenética de publicaciones en revistas y editoriales, de tertulias hasta altas horas de la madrugada y de nuevas amistades. En 1956 publica su segunda obra, La última inocencia, ${ }^{14}$ dedicada a su gran amigo y analista León Ostrov. Ivonne Bordelois describe su relación de esta forma:

Cuando tenía veintiún años, aquejada por el asma y algunos transtornos verbales menores, Alejandra Pizarnik comenzó a tratarse con el psicoanalista León Ostrov, psicólogo, profesor de Psicología Experimental en la

11“Porque, considerada desde esa perspectiva la mayor comprensión que el padre parecía demostrar, por comparación con la madre, ante su hija menor anticonvencional y atraída por una zona de la actividad intelectual y profesional incompatible con los valores ad usum en la familia -tal atracción por los hombres maduros parecería responder a una fijación positiva con la figura del padre, a partir de la cual inconscientemente habría aspirado a reeditar la relación con sus ulteriores objetos amorosos" (C. Piña, op. cit., 1999, 58).

12“De allí el Mito de Mi Amor Imposible: carencia, nada más. Una muchacha sedienta en el desierto y un manantial que no da de beber cuando ella se acerca. ¿Qué sucedería si ella pudiese beber? Ah, muchas cosas cambiarían" (A. Pizarnik, op. cit., 2005, 84).

13“'Hoy cumples veinte años, y por eso te obsequias tus poemas vestidos de fiesta. Te has maquillado, puesto hermosa, y tus labios apagan veinte llamitas.

“Pero la situación real es muy otra. ¡Alejandra! Has vestido de fiesta a tu sangre, a tu angustia. Tú no lo quieres, ¿verdad? Tú deseas escribir silenciosamente, esconderte, no mostrar los poemas a ser humano alguno" (A. Pizarnik, op. cit., 2005, 75).

${ }^{14}$ Alejandra Pizarnik, La última inocencia, Buenos Aires, Poesía Buenos Aires, 1956. 
UBA, poeta a veces y ensayista de perfil humanista muy personal, apasionado lector de Dostoievsky, que solía abogar por nuevas perspectivas en los caminos de la terapia - como lo prueba su Verdad y caricatura del psicoanálisis.

Así nace una relación de diálogo y confianza que perdurará mucho tiempo. Ostrov fue una suerte de padre literario para Pizarnik, quien le dedicó La última inocencia (Poesía Buenos Aires), su segundo libro, en 1956, y uno de los poemas de Las aventuras perdidas (Altamar, 1958), 'El despertar' [... ]

I. Bordelois, op. cit., 47

En ella laten las nuevas inquietudes (que permanecerán de por vida) que la acechaban sin descanso. Poesía, noche, muerte, duplicación del yo ${ }^{15}$ y miedo pelean constantemente por ocupar un pequeño espacio en el maremágnum de destrucción que su pluma provoca en el blanco silencio.

Una de las vinculaciones más influyentes en el devenir intelectual de Alejandra Pizarnik será su vinculación con el grupo Poesía Buenos Aires, en el que participarán las nuevas voces poéticas de la capital: Rodolfo Alonso, Rubén Vela, Edgar Bayley, Elisabeth Azcona Cranwell (su hermana "Liz", que compartía lecturas, clases, poetas y reuniones con ella) y el músico Daniel Saidón, entre otros; todos ellos dirigidos por Raúl Gustavo Aguirre, el director de orquesta de esta renovación poética. A partir de 1950, la vanguardia se canalizará en dos caminos: el seguido por los surrealistas (cuya tendencia es la más vitalista) y el seguido por la revista Poesía Buenos Aires, donde residía la poesía "cerebral". ${ }^{16}$ Durante doce años esta revista se dedicará exclusivamente a este género. Fundada por Raúl Gustavo Aguirre y Jorge Enrique Mobili en 1950, será testimonio de una preocupación por la actividad creadora. A partir del n. ${ }^{\circ} 4$ desaparece Mobili de la dirección, y en los siguientes tres números aparecerá Wolf Roitman. Más tarde la codirección será compartida con estos nombres: Nicolás Espiro, Rodolfo Alonso, Ramiro Casasbellas y Edgar Bayley. La revista irá adquiriendo así consistencia y publicará poemas de Paul Eluard, Tristan Tzara, Dylan Thomas, Vicente Huidobro, Pablo Neruda, César Vallejo, Hans Arp, Pierre Reverdy,

15 “Me compré un espejo muy grande. Me contemplé y descubrí que el rostro que yo debería tener está detrás -aprisionado- del que tengo. Todos mis esfuerzos han de tender a salvar mi auténtico rostro. Para ello, es menester una vasta tarea física y espiritual" (A. Pizarnik, op. cit., 2005, 130).

${ }^{16}$ Francisco Urondo, Veinte años de poesía argentina 1940-1960, Buenos Aires, Galerna, 1968, 27. 
René Menard, Cesare Pavese, Pessoa, Antonin Artaud, André Breton, Rimbaud, James Joyce, Michaux, Giusseppe Ungaretti, Boris Pasternak, Emily Dickinson y algunos poetas argentinos de las últimas promociones, como Macedonio Fernández, Oliverio Girondo o Juan L. Ortiz.

Aguirre defiende una imagen pura y creada $^{17}$ un elemento simple e intuitivo que no proviene de ninguna representación real o imaginaria. En 1952 publica Antología de la Poesía Nueva, con poetas invencionistas: Juan Carlos Lamadrid, Edgar Bayley, Mario Trejo, Omar Rubén Aracama, Jorge Enrique Mobili, Nicolás Espiro y Wolf Roitman; y en 1953-54 volverá a salir una nueva antología, en la que se comprueba el fenómeno de transición cultural del que todos esos poetas son testimonio. Poesía Buenos Aires, ${ }^{18}$ a pesar de la labor poética que cumple durante este periodo, quedará lejos de un público significativo socialmente. ${ }^{19}$ Obviamente, esta corriente central nada tiene que ver con el imaginario poético pizarnikiano, ajeno a estas corrientes poéticas y políticas. $^{20}$

17“Ya no describimos la visión en su cocina ni en su trastienda secular de vigilia o de impotencia, ya no pintamos la anécdota, la fraguamos; le inventamos privilegios a la acción humana recapacitando los vínculos frente a la angustia sideral; el hombre vive asociado y no pierde su universo ni salud de su voluntad de siempre" (texto de Jorge Enrique Móbili en AA.VV, El movimiento Poesía Buenos Aires (1950-1960), selección de Raúl Gustavo Aguirre, Buenos Aires, Editorial Fraterna, 1979, 25).

${ }^{18}$ Tal y como indica Gema Areta: "Protegida por el movimiento Poesía Buenos Aires que publicaría su segundo poemario (también el tercero en la editorial Altamar), Alejandra Pizarnik se incorpora en carne viva a las exigencias malditas de la poesía, a ese "no sabemos qué es la poesía y, mucho menos, cómo se hace un poema", al asedio incesante del rumor secreto en la gran ciudad (Buenos Aires como ciudad de estructura oceánica), y esa inocencia con la que siempre puede volcarse hacia una nueva pregunta y una nueva esperanza" (Gema Areta, "La textura de la oscuridad, El castillo frío de Alejandra Pizarnik", en Areta Marigo, Gema [ed.], Le Corre, Herve [ed. e intr.], Suárez, Modesta [ed. e intr.] y Vives, Daniel [ed. e intr.], Poesía hispanoamericana, Ritmos(s)/métrica(s)/ruptura(s), Madrid, Verbum, 1999, 272).

${ }^{19}$ Francisco Urondo, op. cit., 35.

20 “La intención de un Aguirre, por ejemplo, o la de un Urondo o la de Pizarnik, no son idénticas ni pretenden serlo pero demuestran esa apariencia común que es la de querer obtener una idea, una sugerencia, una necesidad. No siempre el fin es el mismo, de ahí los gustos. Pero ¿qué es el gusto sino el desarrollo incesante de una práctica extraordinaria? Cuando el culto de lo extraordinario se convierte en producción cotidiana, seriada, entonces se desarrolla lo ordinario" (Raúl Vera Ocampo, "Algunos datos sobre la última poesía argentina", Buenos Aires, Sur, 1969, 125). 
En el ambiente humeante de alcohol y poesía que se respiraba en los círculos literarios del momento, A. Pizarnik encontrará su voz propia, aquella que se sumerge en las olas funestas y destructivas de la muerte, el desamparo, la noche y la subjetividad completa. Toda esta amalgama de pesimismo y soledad se darán cita en un nuevo libro de poemas: Las aventuras perdidas (1959). ${ }^{21}$ Esta nueva obra, dedicada a Rubén Vela, ${ }^{22}$ desempeña una función recopiladora de todo lo poetizado anteriormente para dar un paso hacia delante y preparar el nuevo camino parisino. En él, A. Pizarnik se deja seducir por la muerte para huir de una realidad que la convierte en exiliada incluso de su propio nombre. Este desarraigo es múltiple: es una caída al chocar con el muro objetivo de la realidad; es un desamparo provocado por la llegada de la adolescencia y de la madurez, dejando de lado la plenitud inocente de la infancia, ${ }^{23}$ y es la exclusión de sus propios pensamientos y sentimientos, debido a las limitaciones que el lenguaje ejerce y que ahoga el intento de catarsis poética.

Hasta 1959, año en que su destino cambiará de rumbo hacia la libertad incondicionada, Alejandra aumentará su círculo social: será un personaje indispensable en todos los cafés, fiestas, comidas y demás cadáveres exquisitos; se convertirá en la niña desvalida alejada de lo cotidiano que provocará la compasión y ternura de todos sus amigos. Entrará en el grupo Equis gracias de nuevo a Roberto Juarroz y allí conocerá, entre otros, a Peltzer y a

La propia Alejandra se define como "huérfana" de maestro en su diario: "No oculto que me gustaría tener un maestro literario. Pero mi situación de huérfana no es deplorable: hay libertad, mi única libertad, por el momento" (A. Pizarnik, op. cit., 2005, 88).

${ }^{21}$ A. Pizarnik, Las aventuras perdidas, Buenos Aires, Altamar, 1958.

22 "Pero sí hay mucho que decir de tu última carta. Desde hace muchos años no he sentido una alegría tan enorme, la he llevado conmigo, tan junto a mí, tantos días, la he releído tanto... Quisiera, cuando pueda reunir en un volumen mis poemas, dedicártelos. Ello sería un muy pequeño testimonio de mi agradecimiento por tu adhesión, por tu gran apoyo" (Carta a Rubén Vela, sin fecha, I. Bordelois, op. cit., 37).

23 “Insomnios dedicados a la infancia tan lejana. Infancia lamentable, rota, como una buhardilla llena de ratones y de carbón inútil. He intentado rescatar un solo recuerdo hermoso pero no lo he conseguido. Todo lo contrario: a medida que me alejo en el tiempo me veo más desdichada, en dificultades con la gente, hastiada, 'niña falsa y enferma de los suburbios tenebrosos'. Ahora me pregunto cómo logré sobrevivir, cómo no me aniquilaron absolutamente" (A. Pizarnik, op. cit., 2005, 126127). 
Mario Morales. Añadirá a su biblioteca particular dos de los libros que más van a influir en su quehacer literario: De Baudelaire al Surrealismo, de Marcel Raymond, y El alma romántica y el sueño de Albert Béguin, libro amado y releído hasta la saciedad.

Además de las tertulias y las revistas, otros puntos de encuentro importantes en el Buenos Aires de mitad del siglo XX fueron las librerías. A ellas acudía A. Pizarnik para tomar contacto con nuevos poetas jóvenes. Librerías como "Letras", "Verbum" o "Galatea" componen el marco ideal para dar a conocer su poesía y para recopilar la información suficiente y necesaria sobre lo que se cocía en la capital de la poesía argentina. Allí conectó con otras poetas como Susana Thénon, que, junto con Olga Orozco (amiga poética y confidente de desconsuelos), se convertirá en la compañera ideal de diversión, humor e ironías, jácaras que plagaban sus poemas más procaces.

Paralelamente a esta vida de desorden y desconcierto, Alejandra seguía haciendo vida universitaria, aunque nunca se presentó a ningún examen final, debido a la repulsa que sentía por esos profesores de literatura incapaces de crearla ni vivirla, sólo de odiarla y destruirla con sus sermones magistrales: "También di algunos exámenes en esta inefable Facultad de Letras en la cual me siento muy asfixiada, blasfemo y conjuro. Pero por ahora continuaré en ella" (Carta a Rubén Vela, sin fecha, I. Bordelois, op. cit., 39).

Pero, a pesar de esa postura, la carrera universitaria le aporta un sinfín de nuevos conocimientos, obras, escritores y corrientes filosóficas, como García Morente, Hegel, Dilthey, Junger, Bollnow o Kierkegaard; y también nuevas amistades, como Edgardo Cozarinsky y Sylvia Molloy.

\section{El sueño parisino (1959-1964)}

Será en el año 1959 cuando empezará su viaje hacia Occidente, el ritual de paso hacia un nuevo cosmos poético, la madre de su poesía, aquella que la ha alimentado estando tan lejos: París.

En cuanto a París, si me preguntas cómo hago para ir, no sé qué responder. Pero me tomaré un barco blanco y grande, con mi saco Montgomery y mis anteojos negros, sin un céntimo como siempre y me iré. Lo esencial es querer algo y yo quiero ir. Lo demás se arreglará. Por otra parte, no me importa si se arregla o no. Lo esencial, como tú dices, es vivir, la vida.

Carta a Rubén Vela, sin fecha, I. Bordelois, op. cit., 44 
Las máscaras de A. Pizarnik se trasladan del baúl familiar de Buenos Aires a la libertad disoluta en 1959. París se convertirá en el espíritu de la poesía puramente pizarnikiana. Primero vivirá durante unos días en casa de sus tíos (Armand, Geneviève y su hija Pascale), ligada de nuevo a la hegemonía familiar. Pero este lazo familiar terminará cuando se traslade de su residencia familiar a sus estudios parisinos (primero al Boulevard Saint Germain, Rue du Bac; después al n. ${ }^{\circ} 30$ de la Rue Saint Sulpice; más tarde, durante algunos meses, a casa de una amiga; y, por último, al Boulevard Saint Michel), recreando de nuevo sus paredes llenas de papeles, su tabaco en cada esquina y sus poemas "colgantes" en cada rincón y en cada pared. A propósito del "departamento" de la Rue Saint Sulpice, Ivonne Bordelois dice lo siguiente en el prólogo de Correspondencia Pizarnik:

La palabra departamento es un eufemismo en este caso; se trataba más bien del navío ebrio de Rimbaud, una zona de tabaco intenso y entrevero prodigioso de libros y papeles, una tienda nómada donde imperaba un samovar y esa atmósfera especial que crece en los lugares en donde el silencio crece como una madreselva invasora, nocturna, permanente; el silencio y una concentración estática y vibrante, donde la voz de Alejandra reinaba.

I. Bordelois, op. cit., 15

Sumergida en la caóticamente ordenada ciudad del surrealismo, A. Pizarnik empieza su maratoniana búsqueda de un resurgir de las cenizas adolescentes. Allí se integra en una ajetreada vida social plagada de escritores franceses y argentinos, $y$, ante todo, de nuevos amigos imprescindibles a partir de aquel momento: Julio Cortázar, Octavio Paz, Italo Calvino y André Pieyre de Mandiargues.

También en París mostrará sus anteriores máscaras bonaerenses: será una Alejandra sutil, clarividente, capaz de convertir cualquier necedad en poesía; pero, por otro lado, podrá ser la peor compañera, que la llevará a transformarse en ese monstruo de fauces imprevisibles declamatorias de ironías, sarcasmos y exasperaciones varias:

Pero aquí me asalta y me invade muchas veces la evidencia de mi enfermedad, de mi herida. Una noche fría fue tan fuerte mi temor a enloquecer, fue tan terrible que me arrodillé y recé y pedí que no me exilaran de este mundo de odio, que no me cegaran a lo que no quiero ver, que no me lleven adonde siempre quise ir.

Carta a Antonio Beneyto, sin fecha, I. Bordelois, op. cit., 58 
Era feliz. Vivía en la fiesta de lo ignoto, de lo subjetivo; en la algarabía antiburguesa; en el galimatías onírico de la poesía por la poesía.

La pasión por los poetas malditos, los surrealistas, los románticos como René Daumal o Henri Michaux ${ }^{24}$ esta coincidencia intelectual será lo que la lleve a iniciar una relación de afecto personal e intelectual con Cortázar. Con él no sólo compartirá los gustos y la poesía; Cortázar adoptará también el papel de tutor alimenticio de una Alejandra despreocupada por su manutención, ${ }^{25}$ enarbolada por la mano espiritual de la ciudad embrujada. Tal vez por ello le proporcionaba, junto con Octavio Paz — que en aquellos años era agregado cultural de la embajada de México en Francia-, algunos textos para corregir de la revista Cuadernos para la Libertad de la Cultura de la Unesco o algún trabajo que redactar. Su amistad se perpetúa también en sus obras:

Alejandra, mi bicho,

vení a estas líneas, a este papel de arroz

dale abad a la Zorra,

a este fieltro que juega con tu pelo

$[\ldots]$

¿Ves, bicho? Así. Tan bien y ya. El scotch,

Max Roach, Silvina Ocampo,

alguien en la cocina hace café

su culebra cantando

sus terrones un beso

Lés Ferré

No pienses más en las ventanas

el detrás el afuera

Llueve en Rangoon-

Y qué.

24 ¿Llegará el día en que mi soledad sea fuerte y consciente de sí misma? Hoy he pensado en ello. En verdad, somos solos por esencia, por naturaleza. Soy yo y todas las que fui, como diría Michaux" (A. Pizarnik, op. cit., 2005, 132).

${ }^{25}$ “Comienzo a darme cuenta. La economía existe. La política existe. Todo eso existe a causa de que yo no puedo pasarme el día leyendo y haciendo mis poemas. Pero aún me parece tan absurdo, tan irreal que yo tenga que trabajar para vivir..." (A. Pizarnik, op. cit., 2005, 190-191). 
Aquí los juegos. El murmullo (consonantes de pájaro vocales de heliotropo)

Aquí, bichito. Quieta. No hay ventanas ni afuera y no llueveen Rangoon. Aquí los juegos. 26

Otro de sus protectores parisinos será Octavio Paz, que en aquellos momentos estaba instalado en tierras francesas debido al desempeño de uno de sus cargos diplomáticos. Tal será la amistad que nacerá entre ellos en esos años que Paz se encargará de prologar su siguiente obra, Árbol de Diana.

Junto a ellos y a Elena Garro, recorrerá los círculos sociales más exquisitos de los literatos parisinos, compartiendo jolgorio, poesía y pintura, deslumbrada por el extravagante quehacer francés y las inauditas experiencias que en sus poemas correrán como sangre descontrolada. Este selecto círculo contará con la presencia no sólo de Paz, Garro, Cortázar y Aurora Bernárdez, sino también de Elvira Orphée y Miguel Ocampo, Eduardo Jonquière, Esther Singer e Italo Calvino, André Pieyre de Mandiargues, Laura Bataillon, Paul Verdevoye, Roger Caillois y Héctor A. Murena. También retomará su amistad con los antiguos compañeros de universidad afincados en París, como Roberto Yahni, Ivonne Bordelois o Sylvia Molloy. Les obsequiará con fiestas literarias poéticas cargadas de humor y obscenidad. Descubrirá nuevos autores en las librerías francesas (Ives Bonnefoy, Blaise Cendrars, Antonin Artaud ${ }^{27}$ Georges Schehadé, Stéphane Mallarmé, Alphonse Allais) y se perderá en los pasillos laberínticos de los museos y exposiciones para descubrir a pintores de la talla de Paul Klee, Joan Miró, Gustave Moreau u Odilon Redon. ${ }^{28}$

${ }^{26}$ Julio Cortázar, Obras Completas, Barcelona, RBA/Instituto Cervantes, Vol. IV, 2006, 250-256.

27 “No quiero consignar mi estado mental. He hojeado las obras de Artaud y me contuve de gritar: describe muchas cosas que yo siento -en esencia: ese silencio amenazador, esa sensación de inexistencia, el vacío interno, la lucha por transmutar en lenguaje lo que sólo es ausencia o aullido-; y también habla de los períodos de tartamudez: la lengua rígida, la asfixia" (A. Pizarnik, op. cit., 2005, 147).

${ }^{28}$ Tête de jeune fille (Odilon Redon)

de música la lluvia

de silencio los años

que pasan una noche

mi cuerpo nunca más 
Los juegos de palabras, la ironía y las historias eróticas ensordecerán el silencio de lo cotidiano, todo ello exacerbado con una imagen excéntrica e insólita, una vestimenta de pantalones y suéteres amplísimos, cara lavada y sin maquillar, colores peleados y cabellera al viento. Tal vez sea ese infantilismo prolongado la causa de su búsqueda de atención, de su ansiada protección, de su provocación afectuosa hacia todo aquel que la conocía. Su poesía, su literatura, la cegaba, la escondía de lo rutinario; su realidad se transformaba en un sinfín de formas irregulares; la geometría del convencionalismo resbalaba sin dejar huella por los espacios poéticos de su obra.

PARA OSIAS

a Muelos Ailes, y en 170 de la zéfira autumnal

inventé un féretro de mimbre

¡para verano! (ja-bú-bú! que mega de Miguel

de

Unamona!

Tengo miedo de la tomboctul!)

Carta a Osias Stutman, 25-VIII-1970, I. Bordelois, op. cit., 157

Este no querer ver se acentúa a partir de 1963, cuando su inestabilidad psíquica hace que su hilo vital se desvirtúe en vaivenes depresivos y la convierta en la otra Alejandra, la que se pone la máscara de la agonía, la que no deja de complacerse con infinitas pastillas, ${ }^{29}$ la que desfallece después de varias desilusiones sentimentales, pensando que sólo algo como el amor es capaz de salvarla de su muerte azul.

podrá recordarse

a André Pieyre de Mandiargues

29 “Reconocido mi naturaleza viciosa: necesito vivir ebria. Si no es de alcohol que sea de té, de café, de ácido fosfórico, de tabaco muy fuerte. Necesitaría drogas: no las tengo, no las busco. Cuando no tenga que despertarme al alba para ir a trabajar 'para vivir' me procuraré 'olvidantes' más poderosos, todo lo que la naturaleza y la ciencia han dado a conocer hasta el presente. Esto no está mal ni bien. Esto demuestra, simplemente, que algunos no pueden vivir. Quiero decir, sólo después de haber tomado diez cafés y tragado varias pastillas de 'revitalizantes cerebrales' puedo respirar con libertad, andar sencillamente por las calles sin que el deseo de matarme se haga imperioso" (A. Pizarnik, op. cit., 2005, 261). 
Su poesía se difundirá internacionalmente a través de las revistas francesas Les Lettres Nouvelles, Nouvelle Révne Française, Mito, etc. Su difusión se complementa con varias lecturas públicas junto a Juarroz, Olga Orozco y Arnaldo Calveyra, en el ámbito universitario.

Estos años de fervor poético serán los causantes de sus poemas más perfectos, incluidos en Árbol de Diana (1963) y publicados en las revistas Sur, Poesía=Poesía, Documento Sud (Nápoles) y Les Lettres Nouvelles, Le Chien de Picque, y en las antologías Poesie vivante en Argentine, de Fernand Verhesen; Antología de la nueva poesía argentina, de Juan Carlos Martelli; y Quince poetas argentinos, de César Magrini; y también de otros poemas más tardíos que aparecerán en Extracción de la piedra de la locura o Los trabajos y las noches.

Durante su estancia en París realizará pocos viajes fuera de la gran urbe: el primero a Capri, en 1961; el segundo a Saint Tropez, en 1962; y, en tercer lugar, recorrerá las tierras españolas en 1963 junto con una amiga, Marie Jeanne, desde donde escribirá el inédito Escrito en España, prosas reunidas por la misma Marie Jeanne Noirot:

[... ] porque decidí partir a lo de la Mère Espagne étant donné que nuestra amiga Marie Jeanne tenía justo un espacio a su lado en su automovilcito rojo el cual cuyo espacio correspondía muy bien a las escasas dimensiones de mis posesiones posteriores de lo que ese colige que no dudé un solo minuto y en seguida alimenté mis ojos con campos de castilla, campos de soria, campos de Santiago, campos descampados que me dieron reposo alegría. No es esto todo, naturlich, también le di a mis ojos cuadros y rostros, iglesias y señoras de negro, que en este sentido es lo que más abunda.

Carta a Ivonne Bordelois, 5-VIII-1963, I. Bordelois, op. cit., 228

Los disfraces de A. Pizarnik se hacen más procaces en su obra parisina; su duplicidad ontológica se ve reforzada por la soledad inseparable del amor metamorfoseado en muerte. El espacio se revaloriza y le otorga un lugar especificativo dentro de su poética. Entretanto sus palabras, sus letras, toman la voz de la profecía, de la universalidad subjetivizada, del carácter visionario redentor de la vida misma. A partir de la estancia en París, los poemas se tornarán breves; las palabras, más simples que nunca, adquirirán un valor simbólico y provocarán la lejanía de una de sus máscaras líricas. Las palabras secuestrarán la vida asesinando aquel referente impuesto por un convencionalismo social:

En mi caso, las palabras son cosas y las cosas palabras. Como no tengo cosas, como no puedo nunca otorgarles realidad las nombro y creo en su 
nombre (el nombre se vuelve real y la cosa nombrada se esfuma, es la fantasma del nombre). Ahora sé por qué sueño con escribir poemas-objetos. ${ }^{30}$ Es mi sed de realidad, mi sueño de materialismo dentro del sueño.

\section{A. Pizarnik, op. cit., 2005, 326}

El yo poético y el rutinario, el cotidiano, serán diferentes. A. Pizarnik adopta así la ética de los poetas malditos, de los románticos alemanes y de los surrealistas. ${ }^{31} \mathrm{El}$ acto poético se convierte en el único camino hacia el conocimiento total del mundo a través de la subjetividad. No será poeta; no escribirá poemas, sino que vivirá mientras lo haga rebelándose de este modo ante la realidad degradada impuesta. Adoptar esta postura puede traer terribles consecuencias. Rimbaud (que ya había pasado el umbral hacia la irrealidad ${ }^{32}$ ) se suicidará poéticamente a los 19 años y morirá más tarde en un país africano en el que se dedicaba a la cacería. Éste fue también el final de muchos de los poetas románticos, del mismo modo que lo será de A. Pizarnik. Es en este periodo cuando inicia un camino sin retorno hacia la vida a través de la poesía.

París no será solo un gaudeamus de jolgorio y regocijo. La desolación y el desquiciamiento laten tras las chanzas francesas; su yermo descorazon-

\footnotetext{
${ }^{30}$ Este poema-objeto debe insertarse en un haz de relaciones al que la poética de Girri no es ajena. Así, Saúl Yurkievich afirma a propósito del poeta argentino: "la posible indagación del poema en el contexto objetivista y prosario de los cincuenta y sesenta, de la ofensiva antirromántica y antipsicológica prevé como cuestionamiento texto en busca de su ser y manifestarse intrínsecos y como intermediario entre mente y mundo".

31 “La poesía, no como substitución, sino como creación de una realidad independiente -dentro de lo posible- de la realidad a la que estoy acostumbrada. Las imágenes solas no emocionan, deben ir referidas a nuestra herida: la vida, la muerte, el amor, el deseo, la angustia. Nombrar nuestra herida sin arrastrarla a un proceso de alquimia en virtud del cual consigue alas, es vulgar. [...] La mayor parte de los poemas surrealistas son mucho menos convencionales y cerebrales y literarios que los poemas sencillos y beatos a que nos acostumbró la literatura española" (A. Pizarnik, op. cit., 2005, 798-80).

32 “Esta descomposición, en cuyo ámbito está ya comprendida en Baudelaire la "deformación", se convierte en Rimbaud en el procedimiento efectivo de la poesía. En la medida en que puede decirse que existe todavía realidad (o que nosotros podemos medir heurísticamente el poema tomando la realidad como criterio), ésta es objeto de dilatación, de descomposición, de afeamiento, de tensiones de contraste, hasta tal punto que siempre viene a constituir una forma de paso a lo irreal" $(\mathrm{H}$. Friedrich, Estructura de la lírica moderna, Barcelona, Seix Barral, 1974, 102).
} 
ador inunda su poesía como único principio inherente. Los límites del yo se han puesto en juego con una ascesis invertida. El sexo, las drogas y el alcohol se conjuran para que esos límites acaben en la locura, el suicidio o la muerte. Sus mentores (Rimbaud, Isidore Ducasse, Artaud, entre otros) dibujarán la vereda antisocial que llevará a Alejandra a vivir a través de la subjetividad poética y la arrojará a las puertas de la muerte (poética o real, según se quiera). Todo ello se produce como manifestación contra la censura de un mundo regido por el orden social burgués. La única salida será escribir poesía poniendo en juego la cordura, e incluso la vida, atrapándose a sí misma en una literatura carcelaria como si a una niña ingenua se la castigara por vivir. A. Pizarnik empieza a recurrir a esta práctica ya en París, pero será sobre todo en Buenos Aires donde este juego llegue a su último episodio.

En 1963 verá la luz una de sus obras en prosa más importantes, una mirada cara a cara con la muerte, la historia de la condesa del castillo de Csejtne, Erzébeth Báthory, ${ }^{33}$ asesina y torturadora ritual de más de seiscientas cincuenta muchachas. La condesa sangrienta, al más puro estilo de Láutreamont, Bataille o Sade, escritores recuperados por el afán anticonvencional del movimiento surrealista, recupera un mundo preedípico en el que el ser humano aún no ha sufrido el trauma socializador, un universo de sexo, muerte, sadismo y goce pasional desmesurados.

\section{Regreso a Buenos Aires (1964-1972)}

En 1964, A. Pizarnik regresa a su ciudad natal, Buenos Aires, debido a la presión familiar y a una enfermedad de su madre: "parece que tendré que ir nomás pues mi pobre madre anda en nostalgias; me dice además, que la han operado, me lo dice sin darle importancia" (Carta a Ivonne Bordelois, 5-VIII-1963, I. Bordelois, op. cit., 229). Retorna con la madurez adquirida gracias a Árbol de Diana y como figura poética ilustre, y también con varios contactos interesantes. Con su ya consabida ansiedad social reanuda sus vínculos con los círculos más prestigiosos, culturales e intelectuales, incluso

33 “Ensayo sobre la condesa Báthory. [... ] La pura bestialidad. Se puede ser una bella condesa y a la vez una loba insaciable. En verdad, la tendencia al mal es común a todos. En lo que respecta a mi imaginación, su única característica -no mía exclusivamente- es su desenfreno. Nunca nada la limitó. Falta de cuadros, de arquetipos, de ejemplaridad" (A. Pizarnik, op. cit., 2005, 397). 
llegando a ser la Virgilio de alguno de sus amigos dándolo a conocer dentro del ámbito secular en el que un escritor debe difundir su obra. Su condición de extranjería vuelve a hacerse patente en sus diarios tras abandonar la que tal vez fue su única patria, París:

Por mi sangre judía, soy una exilada. Por mi lugar de nacimiento, apenas si soy argentina (lo argentino es irreal y difuso). No tengo una patria. En cuanto al idioma, es otro conflicto ambiguo. Es indudable que mi lugar es París, por el solo hecho de que allí el exilio es natural, es una patria, mientras que aquí duele.

A.Pizarnik, op. cit., 2005, 397-398

Sus lugares más visitados serán la Galería Bonino, la redacción de las revistas Sur y Capítulo, la Casaquinta de Esmeralda Almohacid y algunos restaurantes, como el "Edelweiss", o los bares de la zona de Florida. A pesar del prestigio adquirido en París gracias a sus últimas obras, A. Pizarnik seguirá padeciendo penurias económicas, de forma que su mecenas seguirá siendo su propia familia, aunque también obtendrá algún ingreso gracias a la beca Guggenheim ("Tensión en la espera del resultado de la beca, más importante de lo que yo creo - en apariencia me interesa la suma mensual que importa-." (A. Pizarnik, op. cit., 2005, 454)), que le fue otorgada en 1968. Ese dinero se lo dilapidará en regalos y utensilios de papelería de lo más variopinto:

[...] sabrás que soy una amourense del papier à écrire, una Gaspara para la Stampa de la estampa, una Louise Labbé de las imprentas, una Mariana Alcofarado de los tipos (no confundir), una Safo (no confundir) de todo aquello que sea papel, si bien tengo preferencias, ya justificadas, ya irracionales.

Carta a Rafael Squirru, 20-II-1970, I. Bordelois, op. cit., 151

Tal vez fuese por creer en ese concepto del escritor como aristócrata, un aristócrata de gusto delicado pero rebelde contra la sociedad burguesa, amante de la belleza, pero sin dinero. ${ }^{34}$

El año 1968 será un haz de luz en la angosta vida de la poeta. Aparece en ella una fotógrafa que se convertirá en la pareja de A. Pizarnik durante los

\footnotetext{
${ }^{34}$ Ya Baudelaire hizo referencia a este aspecto en sus Escritos íntimos con su famoso verso "¿Qué es el arte? Prostitución” (Charles Baudelaire, Escritos íntimos, Murcia, Universidad de Murcia, 1994, 55).
} 
dos años siguientes, y que provocará la consiguiente mudanza al n. ${ }^{\circ} 980$ de Montevideo. Este nuevo espacio se volverá a llenar de fiestas pizarnikianas efervescentes de luces, comidas, retozos y esparcimientos. Todo su mundo renacerá del silencio nocturno, pero, con él, también el de las pastillas, tan necesarias para explorar la noche, el lenguaje y el sueño. Gracias a la beca Guggenheim viajará a Nueva York, ciudad que no le aportará nada nuevo, tan sólo insomnio y ataques de asma:

New York me horrorizó; el Village apenas me hizo sonreír, y cuando tengas tiempo y ganas te ruego explicarme cómo es posible vivir en E.E.U.U. No fui a Harvard a ver a Ivonne ni a Iowa a verte a ti porque contaba los minutos que faltaban para huir de la Gran América. Por fin me fui a París, mi 'patria secreta' (cierto París, naturalmente).

Carta a Monique Altschul, 1-V-1969, I. Bordelois, op. cit., 281

Agrego que mi terror a tener que quedarme en N.Y. se acompañó de dos ataques de asma agravados por el pequeño detalle de la prohibición de vender medicamentos.

Carta a Ivonne Bordelois, 19-V-1969, I. Bordelois, op. cit., 284

Uno de los puntos de encuentro más reiterados será la galería de arte ingenuo El Taller, inaugurada en 1963 por Nini Gómez, Nini Rivero y Leonor Vaguna. Allí se reunirán los escritores y pintores más destacados de la época: Alberto Girri, Raúl Vera Ocampo, Enrique Molina, Olga Orozco, Manuel Mújica Láinez y todos los relacionados con la revista Sur. Esta relación con la pintura se palpará en los poemas de A. Pizarnik y también en la técnica de composición. Se encerrará en su estudio con un pizarrón para "dibujar" en él los poemas a través de pinceladas lingüísticas, buscando la ubicación exacta y perfecta para cada palabra, dejando huecos o trasladando palabras hasta divisar, a lo lejos, la perfección de la totalidad de su poema-dibujo.

A. Pizarnik intensificará su relación con los componentes de Sur y, de esta forma, tendrá acceso a diversas personalidades que viajaron a Buenos Aires durante aquellos años, como Hans Magnus Enzenzberger o Evgeni Evtuchenko. ${ }^{35}$ En esta misma revista iniciará su relación con Silvina Ocampo, con la que compartirá juegos y humor verbal, dilapidando genialidad

\footnotetext{
${ }^{35}$ Evtuchenko afirma: "No basta saber escribir versos, hay que ser también capaces de defenderlos". Es aquí donde enlaza con la poética de Pizarnik, teniendo en
} 
como dos niñas perversas capaces de transformar el lenguaje en ecos delirantes y crueles.

cuenta que en 1960, estando en París al mismo tiempo que la poeta, probablemente coincidió con ella y ésta leyó poemas suyos como "En el puente":

Una mujer y un hombre solos, en un puente,

Sobre el dormido Sena azul.

Debajo está el tumulto sin sentido,

Las luces irreales.

Cambia el gobierno en algún sitio, se pronunciaban sabios discursos.

Pero ellos desde el puente, apenas si lo ven:

tan sólo ven el Sena

Turbio y lento.

Así están, sin palabras

$\mathrm{Y}$ sin besos,

hasta la madrugada, bajo un impermeable,

como un paquete envuelto en celofán,

¡un regalo del mundo

para el mundo entero!

¡Quiera Dios que no tengamos

ni casa

ni hacienda,

ni aturdidora comodidad en nuestra vida!

¡Quiera Dios

que, estemos donde estemos,

siempre nos encontremos en el puente!

En el puente

para siempre inscrito en el cielo.

En el puente que hace sagrado a quien le habita.

En el puente

sobre el tiempo,

Sobre toda

la vanidad y la mentira...

París, 1960

(Evgueni Evtuchenko, Entre la ciudad sí y la ciudad no,

Madrid, Alianza, 1971, 8, 19 y 20) 
Será en estos años cuando A. Pizarnik componga su siguiente obra, Los trabajos y las noches, ${ }^{36}$ que verá la luz en junio de 1965. En un principio, el libro se iba a titular Visiones y silencios; visiones, en referencia a la visualidad y lo onírico de la imagen típica surrealista; silencios en los que desemboca la procaz combinatoria de las palabras poéticas. ${ }^{37}$ Las palabras alcanzarán de nuevo una significación de potencia inalcanzable, pero serán la muerte y la pérdida las que ocupen todo el espacio poético. En los primeros poemas el amor aparecerá de soslayo, asimilándose a la muerte; un amor perdido, degradado al lugar más ínfimo del ser, un ser sustentado por la poesía, sustancia ontológica que le dará la vida pero que también se la arrebatará. El lenguaje será salvación y condena, música y silencio; pero sin él sería incapaz de vivir.

Gracias a esta última publicación, en noviembre de 1966, recibirá el Primer Premio Municipal de Poesía, festejado en Edelweiss con todos sus compañeros de pasión y desasosiego. Este círculo se verá ampliado con un miembro más, Marcelo Pichon Rivière, camarada surrealista fascinado por el humor, el erotismo, la novela gótica inglesa y poetas como Schehadé, Trakl, Paz o Michaux, tan del gusto de Pizarnik. Pero, ante todo, Marcelo representa el ingreso de A. Pizarnik en su segunda fase psicoanalítica, puesto que el padre de éste, Enrique Pichon Rivière, será el nuevo diván intelectual de la duplicidad pizarnikiana y de su obsesiva redención ante la muerte. ${ }^{38}$ Esta obsesión se intensificará a partir de enero de 1966, cuando Elías Pizarnik, padre de la poeta, fallezca. La muerte pasará de ser una simple compañera vital que adornaba la soledad y acompañaba a sus más diversas máscaras, a ser un personaje fascinante y terrorífico a un mismo tiempo, capaz de diluirse en todos los ámbitos poéticos (humor, sexo, infancia, lenguaje...). A. Pizarnik se retuerce en la niebla del temor y el dolor, ahogada por el lazo de la culpa por la desaparición de la figura paterna.

Con treinta años cumplidos, A. Pizarnik iniciará su particular descenso a los infiernos del submundo para refugiarse en la única fuente de vida, el lenguaje, que llenará la ausencia paterna con la propia poesía asesinando la cosa, lo real ante su cadáver. Esta muerte vivida como propia se hará factible

${ }^{36}$ A. Pizarnik, Los trabajos y las noches, Buenos Aires, Sudamericana, 1965.

${ }^{37}$ César Aira, op. cit., p. 64.

${ }^{38}$ Enrique Pichon Rivière, además de analista fue el primero en realizar las investigaciones sobre la estancia de la familia Ducasse (Conde de Lautréamont) en Uruguay. Publicó sus conclusiones en el n. 2 de la revista Ciclo que codirigía Pellegrini y Elías Pitterberg. 
en Extracción de la piedra de locura, ${ }^{39}$ a partir de la cual su padre pasará a ser el hombre de la mirada azul:

\section{A plena pérdida}

Los sortilegios emanan del nuevo centro de un poema a nadie dirigido. Hablo con la voz que está detrás de la voz y emito los mágicos sonidos de la endechadora. Una mirada azul aureloaba mi poema. Vida, mi vida, ¿qué has hecho de mi vida?

Esta obra la compondrá entre 1962 y 1966 y se la dedicará a su madre, Rosa, tal vez porque seguía cuidándola, ${ }^{40}$ manteniendo en orden el maremágnum vital de su hija hasta tal punto que llegó a regalarle el departamento de Montevideo, 980. El título de esta última obra proviene, como es de sobra conocido, de uno de los famosos cuadros de El Bosco y de otro cuadro con la misma temática de Pieter Brueghel:41 "Quiero componer Les

\footnotetext{
${ }^{39}$ Alejandra Pizarnik, Extracción de la piedra de locura, Buenos Aires, Sudamericana, 1968.

${ }^{40}$ Las atenciones de su madre no siempre eran bien recibidas por parte de Pizarnik: "Mi madre, celosa de mi soledad poblada (al menos en apariencia), agota todos los medios para molestarme y ofenderme. En verdad, vivir con ella es una maldición. Si hay pecados y, por consiguiente un castigo de ellos, el mío es vivir a solas, a los treinta años, con mi madre" (A. Pizarnik, op. cit., 2005, 415).

${ }^{41}$ Hieronymus van Aeken, "El Bosco", dedicó, de forma reiterada, parte de su creatividad a la extracción de la piedra de la locura con un tratamiento hilarante. Plantea la escena rodeada de una leyenda en caracteres góticos en la que se lee "Maestro, quíteme la piedra, me llamo Lubbert Das", nombre tópico de la cultura neerlandesa para designar la máxima estupidez humana. El personaje encargado de la operación lleva un embudo en la cabeza, emblema de la locura, y está acompañado por dos religiosos: un clérigo que bendice el supuesto acto quirúrgico y una monja con cara aburrida que lleva sobre su cabeza un libro cerrado, tal vez símbolo de la superstición y la ignorancia. Cabe destacar que lo que se extrae de la cabeza del campesino no es una piedra sino una flor parecida a la que se encuentra sobre la mesa. Este aspecto, debido al formato circular que envuelve la escena, hace pensar en un espejo, el cual pretende devolver al mundo la imagen de su propia estupidez. Pieter Bruegel, “El Viejo", influenciado por El Bosco, adoptará también el tema de la locura en uno de sus cuadros con el mismo nombre, Extracción de la piedra de la locura. En la escena representada aparecen varios pacientes dispuestos para ser operados en serie: unos sentados en sillas y atados con bandas de tela, otro al que el ayudante del charlatán venda la herida, un paciente ya operado mira divertido a uno de sus compañeros que huía mientras otros le sujetan y el artista de la navaja que sigue
} 
Chants y, asimismo, describir dos cuadros: el de Bosch y el de Brueghel. ${ }^{42}$ El segundo me impresiona más, actualmente. Sobre todo por el frenesí del niño de cubrirse con la máscara" (A. Pizarnik, op. cit. 2005, 462).

La noche y sus presencias (y no serán esta vez algo exterior, sino ella misma) conformarán una de las duplicaciones del yo: el yo cadáver frente al yo niña. Varios son los ejemplos de la duplicidad de A. Pizarnik a través de la onomástica utilizada para referirse a sí misma: Alexandra, Sasha, Alejandra, Sacha, Sachenka... ${ }^{43}$ La muerte será la reestructuradora de la vida y el lenguaje; el silencio atrapará la música y romperá la cuerda del exterior, y creará así una atmósfera combativa y trágica. Lo subjetivo y la cosa ya tienen un asesino, el propio lenguaje que los desfigura y los trasforma en nocturna muerte. Son los tres últimos poemas los que acercarán el yo a la muerte, los que están a punto de cerrar el pacto con la oscuridad:

[...] Escucho mis voces, los coros de los muertos. Atrapada entre las rocas; empotrada en la hendidura de una roca. No soy yo la hablante: es el viento que me hace aletear para que yo crea que estos cánticos del azar que se formulan por obra del movimiento son palabras venidas de mí. $Y$ esto fue cuando empecé a morirme, cuando golpearon en los cimientos y me recordé.

Suenan las trompetas de la muerte. El cortejo de muñecas de corazones de espejo con mis ojos azul-verdes reflejados en cada uno de los corazones. Imitas viejos gestos heredados. Las damas de antaño cantaban entre muros leprosos, escuchaban las trompetas de la muerte, miraban desfilar -ellas, las imaginadas- un cortejo imaginario de muñecas con corazones de espejo y en cada corazón mis ojos de pájara de papel dorado embestida por el viento.

imperturbable con su faena con los instrumentos quirúrgicos a sus pies. Una escena que rebosa "locura" por todos lados.

${ }^{42}$ Cabe recordar que en 1963, A. Girri publicó El ojo, libro reseñado en Sur (278, 1962, 7-11) por A. Pizarnik y en ese libro del poeta argentino aparece ya la fascinación por el motivo de Brueghel. Ahí, el poema girriano "Ejercicios con Brueghel" desarrolla en un tríptico poético algunos versos que Pizarnik sin duda leyó: "De hecho / la visionaria caridad / de enseñarnos con desastres / a comprender lo que somos, / a librarnos / de parecer lo que somos" (Girri, "El ojo", en Obra poética II, Buenos Aires, Corregidor, 1978, 63).

${ }^{43}$ Cfr. I. Bordelois, op. cit. 
La imaginada pajarita cree cantar; en verdad sólo murmura como un sauce inclinado sobre el río. [... $]^{44}$

El viaje a Nueva York no fue su último viaje. En 1969 vuelve a París con el propósito de renovar su energía vital perdida en la melancolía de la muerte, pero, al regresar a la capital francesa, se encuentra con un París baldío, americanizado, insoportable, catapultado de la ciudad tumultuosa, insurrecta y provocadora que antaño fue:

[...] encontré en París algo que me horrorizó: una suerte de americanización — traducida al francés, desde luego- que no me hizo daño pero me dolió que el Flore, par ex., allí donde veía a Bataille, a Ernst, a Claude Mauriac, a Jean Arp, etc, etc, no vi sino jovenzuelos de rostros desiertos con pantalones de gamuza y el uniforme erótico-perverso del hippie de luxe.

Carta a Ivonne Bordelois, 16-VII-1969, I. Bordelois, op. cit., 288

No queda nada del París imaginario; ha crecido, se ha hecho adulto y el surrealismo subversivo se ha acomodado en el sillón burgués. París ya no es la casa de A. Pizarnik; el desencanto y el exilio vuelven al cauce de su vida. París y Buenos Aires ya no le sirven de morada poética; el fuego del hogar añorado se ha extinguido y se refugia en el lenguaje. De este modo escribirá "El hombre del antifaz azul" en Papeles de Son Armadans y Nombres y figuras, ${ }^{45}$ publicado por la editorial española La Esquina en 1969

\footnotetext{
${ }^{44}$ Alejandra Pizarnik, Extracción de la piedra de la locura, Buenos Aires, Editorial Sudamericana, 1968.

${ }^{45}$ Alejandra Pizarnik, Nombres y figuras, La Esquina, Barcelona, 1969. Acerca de éstos dice en su diario:
}

Otra evidencia: de cada veinticinco poemas uno escribe -y esto si tiene suerte- cuatro o cinco poemas válidos. No me quejo. Digo que el movimiento que nos impulsa a escribir un buen poema no se diferencia del que nos hace fracasar. Algo -el azar u otra entidad abstracta- interviene para dotar de gracia algunos poemas.

He reunido 19 poemas para publicarlos en Barcelona. El acto de elegirlos me impidió escribir o seguir el hermoso ritmo de la semana pasada. Esta semana que viene no escribiré bajo pretexto de tener que pasarlos a máquina y mostrarlos a alguien, por ej. a Olga.

A. Pizarnik, op. cit., 2005,475 
y que, junto a otros poemas, conformarán El infierno musical (1971) ${ }^{46}$ En ellos arriesga un poco más si cabe, llegando al filo del acantilado poético que conduce al vacío mortal. La noche, la muerte, el definitivo exilio de la infancia y las duplicidades poéticas serán asumidos por un lenguaje que será su única patria, un lenguaje que la conducirá al silencio, a lo yermo, a lo azul paternal:

\section{Endechas}

\section{I}

El lenguaje silencioso engendra fuego. El silencio se propaga, el silencio es fuego.

Era preciso decir acerca del agua o simplemente apenas nombrarla, de modo de atraerse la palabra agua para que apague las llamas de silencio.

Porque no cantó, su sombra canta. Donde una vez sus ojos hechizaron mi infancia, el silencio al rojo rueda como un sol.

En el corazón de la palabra lo alcanzaron; y yo no puedo narrar el espacio ausente y azul creado por sus ojos.

Ese mismo año publicará su único texto teatral, Los poseídos entre lilas, obra de un solo acto de cariz sexual en el que los personajes se preguntan por la falta de ser e, indirectamente, por el funcionamiento de la creación, todo ello mediante tonos infantiles, humorísticos, irónicos e incluso tangueros.

A los 34 años, después de dos llamadas, una a su médica Rosa y otra a Olga Orozco para despedirse de ella, ingresó en el Hospital Pirovano tras su primer intento de suicidio en $1970 .{ }^{47}$ Allí permaneció interna durante unos meses; tras una maquillada recuperación volvió a su morada poética para retomar la escritura poética, sus diferentes personalidades y, por supuesto, sus fieles pastillas cautivadoras de sueño.

\footnotetext{
${ }^{46}$ Alejandra Pizarnik, El infierno musical, Buenos Aires, Siglo XXI, 1971.

47 “13 de febrero

Aparentemente es el final. Quiero morir. Lo quiero con seriedad, con vocación íntegra.

9 de octubre

Van cuatro meses que estoy internada en el Pirovano.

Hace cuatro meses que intenté morir ingiriendo pastillas.

Hace un mes, quise envenenarme con gas." (A. Pizarnik, op. cit., 2005, 502) 
En 1971 retoma sus publicaciones. Se asociará con López Crespo y juntos publicarán la primera edición de La Condesa Sangrienta, ${ }^{48}$ la traducción de La marea de André Pieyre de Mandiargues y algunos textos de Artaud. También escribirá La bucanera de Pernambuco o Hilda la polígrafa, texto obsceno, desopilante y humeante, cargado de citas culturales, locura, muerte y sexo.

Tras todas esas publicaciones, traducciones y trabajos se percibe una mejoría física. Su vida social sigue. Durante este tiempo conocerá a Ana Becciú y a Ana Calabrese; incluso mantendrá una nueva relación con una mujer que acabará poco antes de su muerte. Será una compleja relación ${ }^{49}$ de amor y odio que acabará con la marcha de dicha pareja a Estados Unidos tras recibir una beca. También a A. Pizarnik le concedieron la beca Fulbright, pero ella la rechazó, debido al viaje que suponía, y se dedicó a escribir para poder mantenerse. De esta forma, ese mismo año publicará su última obra, El infierno musical, en la que aparecerán poemas de esta última publicación junto a "Los poseídos entre lilas" y nuevos poemas recopilados bajo el título "Las uniones posibles". En ellos se produce un cambio que anticipa el trágico final: el silencio ya no es soslayado, sino que lo abrazará como a un amigo; en él encontrará la armonía que proviene de la muerte y de la vida en el lenguaje, un lenguaje que también ahora le falla, dejando sin sentido cualquier atisbo de salvación. A pesar de todo, A. Pizarnik no dejará de lado en estos poemas la obscenidad salvaje y la crueldad irónica que inició años atrás:

\section{L'obscurité des eaux}

Escucho resonar el agua que cae en mi sueño. Las palabras caen como el agua yo caigo. Dibujo en mis ojos la forma de mis ojos, nado en mis aguas, me digo mis silencios. Toda la noche espero que mi lenguaje logre configurarme. Y pienso en el viento que viene a mí, permanece en mí. Toda la noche he caminado bajo la lluvia desconocida. A mí me han dado un silencio pleno de formas y visiones (dices). Y corres desolada como el único pájaro en el viento.

\footnotetext{
${ }^{48}$ Alejandra Pizarnik, La Condesa Sangrienta, Buenos Aires, López Crespo Editor, 1976.

49 “De ninguna manera me parece conducente -ni correcto- inmiscuirme en las alternativas de dicho amor, lo que sí señalo es que para Alejandra fue algo capital, en tanto se trató de una auténtica pasión con infinitos avatares, la cual, inclusive, la llevó a decirle a una amiga poeta que, a partir de esta experiencia, pensaba que se había equivocado en su apuesta vital y que si ahora pudiera la reformularía: no ya la poesía sino el amor" (C. Piña, op. cit., 1999, 190).
} 
En Textos de sobra y últimos poemas, ${ }^{50}$ recopilados por Ana Becciú y Olga Orozco a título póstumo, los versos se trasforman, aún más si cabe, en extrema desesperación y brutalidad.

Su último poema de El infierno musical ${ }^{51}$ simboliza el fin: todo ha terminado, no importa si terminó de forma consciente o fue un descuido, ${ }^{52}$ la Alejandra-poeta ya estaba cubierta de desolación mortal antes de desfallecer, el 25 de septiembre de 1972, sobre el árido suelo de su alma silenciosa. ${ }^{53}$

\section{Proposiciones}

¿adónde fue la obrera enamorada?

¿fue al aire la obrera enamorada?

la obrera de la palabra murió

¿por qué caminito se fue?

${ }^{50}$ Alejandra Pizarnik, Textos de sombra y últimos poemas, Buenos Aires, Sudamericana, 1982.

51 IV

Alguna vez, tal vez, encontraremos refugio en la realidad verdadera. Entretanto ¿puedo decir hasta qué punto estoy en contra?

Te hablo de la soledad mortal. Hay cólera en el destino porque se acerca, entre las arenas y las piedras, el lobo gris. ¿Y entonces? Porque romperá todas las puertas, porque sacará afuera a los muertos para que devoren a los vivos, para que sólo haya muertos y los vivos desaparezcan. No tengas miedo del lobo gris. Yo lo nombré para comprobar que existe y porque hay una voluptuosidad inadjetivable en el hecho de comprobar.

Las palabras hubieran podido salvarme, pero no estoy demasiado viviente. No, no quiero cantar muerte. Mi muerte... el lobo gris... la matadora que viene de la lejanía... ¿No hay un alma viva en esta ciudad? Porque ustedes están muertos. ¿Y qué espera puede convertirse en esperanza si están todos muertos? ¿Y cuándo vendrá lo que esperamos? ¿Cuándo dejaremos de huir? ¿Cuándo ocurrirá todo esto? ¿Cuándo? ¿Dónde? ¿Cómo? ¿Cuánto? ¿Por qué? ¿Para quién?

${ }^{52}$ Esta incógnita también se da en la poeta alemana Ingeborg Bachman, al igual que se pueden encontrar muchas coincidencias con Pizarnik en su poética.

53 “MI EPITAFIO:

Hame acontecido lo que más temía" (A. Pizarnik, op. cit., 2005, 498). 
¿se fue por el camino que los días oscuros tejen como hormigas desesperadas iguales?

¿como vaivén de pases ciegos en un cuarto?

¿tendría la obrera poca luz?

¿y quién le quito la luz a la obrera la constante? ¿quién le fue apagando uno a uno los rostros de la palabra enterrándolos muertos?

¿quién le cegó la luz de la palabra?

¿la obrera se fue porque ya no podía trabajar?

¿el aire estaba sordo mudo roto y ella apenas tenía su confianza en la palabra confianza?

yo digo: mejor no llorar

mejor hacer otro mundo

yo digo: mejor hacer otro mundo

mejor hagamos un mundo para alejandra

mejor hagamos un mundo para que alejandra se quede

oh eternidades débiles perdidas para siempre

y vacas tristes entre la duda y la verdad

y sedas y delicias de la sombra

mejor hagamos un mundo para que alejandra se quede ${ }^{54}$

${ }^{54}$ J. Gelman, De palabra, Madrid, Visor, 1994, 49. Pertenece a la obra Relaciones escrita entre 1971 y 1973. 



\section{Símbolos de la obra poética de Alejandra Pizarnik}

La palabra "símbolo" adquiere un significado diferente según la disciplina que la trate, sea la lingüística, la mitología, la filosofía o la psicología, entre otras, y se va haciendo más compleja según el sentido que le da una $\mathrm{u}$ otra tendencia y las épocas y contextos en que se localiza su uso. Desde la definición del símbolo en los griegos hasta las concepciones antropológicas de Lévi-Strauss, Geertz, Turner o Leach, o las lingüísticas de Saussure, Peirce, Lotman o Barthes; el símbolo revela, evoca, reemplaza, tipifica o transporta, y, además, presenta una dualidad inherente: es capaz de producir la realidad y, al mismo tiempo, es producido por ella. Es en este punto donde entronca con la poesía pizarnikiana: el símbolo permite producir una realidad diferente de la vivida que constituiría la salvación a través de él mismo y, en consecuencia, a través del lenguaje y de la poesía; y viceversa, el símbolo en Pizarnik vive y pervive gracias a sus textos, y es a través de los poemas que el propio símbolo se revela y adquiere su valor intrínseco inscribiéndose en una nueva realidad. Además de los temas principales de la poesía pizarnikiana (muerte, duplicidad, silencio, infancia, noche), son muchos los símbolos que pueblan los versos pizarnikianos, símbolos que pueden convertirse incluso en personajes, pues evolucionan a lo largo de la obra poética. A continuación estudiaremos algunos de ellos.

\section{El universo celeste: astros y bóvedas}

La obra poética de Alejandra Pizarnik es una constante caída desde la celeste infancia a la madurez terrenal. Tras esta caída se produce una 
desmembración poética reflejada en la duplicidad de máscaras y rostros del yo poético:

Alguien

cae

en

su

primera caída.

La falta de nominalidad hace que lo realmente importante de este breve poema sea la caída, el hecho en sí, que es capaz de desmembrar el alma poética en versos monosílabos al tiempo que, mediante la distribución espacial, recrea la sensación visual de un descenso hacia la primera caída en el mundo maduro. Esta caída, al igual que la caída del alma platónica, es la que provocará la partición de la poeta en varias voces y lo que provocará la inmersión en el silencio lingüístico.

La caída se produce desde lo más alto del universo pizarnikiano, el universo celeste. Allí encontraremos diversos símbolos muy relacionados con la infancia y su pérdida irremediable.

Cristina Piña afirma que toda la poesía de Pizarnik es una búsqueda de una salida ontológica tras la clausura de toda posibilidad vital. Acerca de la caída pizarnikiana asevera:

Este itinerario de sigiloso hundimiento en un clima de muerte se cumple a partir de una comprobación fundamental que actúa como núcleo generador de su poesía: el ser humano es un ser caído, separado del absoluto y la unidad; su destino es la temporalidad y la contingencia, vale decir, la muerte en su doble vertiente de multiplicidad y aniquilación.

Piña, op. cit., 1981, 14

En este apartado, el cielo es uno de los símbolos más importantes. Según Chevalier, el cielo es "Símbolo cuasi universal por el cual se expresa la creencia en un Ser divino celeste, creador del universo y garante de la fecundidad de la tierra. [...] Tales Seres (celestiales) están dotados de una presciencia y sabiduría infinitas; las leyes morales y a menudo los rituales del clan han sido instaurados por ellos durante su breve estancia sobre la tierra." ${ }^{25}$ Dentro de estos seres celestiales estarían los símbolos del ángel o el pájaro que veremos en apartados posteriores.

${ }^{55}$ Chevalier, Gheerbrant, Diccionario de los símbolos, Barcelona, Herder, 2007, 281. 
El cielo será espacio para el amor inmutable, un lugar de reflexión contrapuesto a la noche y hogar de la infancia perdida. Ya en su primer poema de La tierra más ajena, el cielo aparece como símbolo de lo sublime, de aquella parte perdida que no se puede alcanzar en esta vida: "no querer vivir mil oxígenos/nimias cruzadas al cielo". El cielo se compadece de ella, acompaña en algunas ocasiones al sentimiento sombrío de orfandad celestial y se funde con la tierra sombría:

"el cielo gime montones desteñidos

sombras mojadas recogen sus trozos"

En el poema "Cielo", dicho símbolo aparece de nuevo, pero esta vez ligado al amor inmutable, al amor infinito que siente la poeta y que se refleja en las nubes. Los dos, al mismo tiempo, crean ya una duplicidad de sentimientos precursora del posterior resquebrejamiento del alma:

"cielo trozo de cosmos cielo murciélago infinito

inmutable como los ojos de mi amor

pensemos en los dos

los dos tú + cielo $=$ mis galopantes sensaciones

biformes bicoloreadas bitremendas bilejanas

lejanas lejanas"

La inocente niñez deambula por esos cielos platónicos e inalcanzables; ella se encuentra entre el cielo y la tierra, lugar efímero en el que todo muere bajo la noche. Ahora ya no sabe cuál es su objetivo, está atrapada entre los dos mundos:

“He aquí lo difícil:

caminar por las calles

y señalar el cielo o la tierra."

Uno de los símbolos más recurrentes de este universo celeste en la obra de Alejandra Pizarnik será el sol. Cirlot afirma que "el sol es el astro de la fijeza inmutable", tal y como sucede en la poesía pizarnikiana. "Por eso revela - continúa diciendo - la realidad de las cosas, no sus aspectos cambiantes como la Luna. [...] En sentido afirmativo, este arcano simboliza gloria, espiritualidad, iluminación. ${ }^{\prime \prime 56}$

${ }^{56}$ Cirlot, Diccionario de símbolos, Madrid, Siruela, 2005, 423. 
En sus primeras obras será un sol amarillo relacionado siempre con una luz, ${ }^{57}$ que no ilumina sino que conduce a las tinieblas; será un sol causante irremediable del paso del tiempo. Por ello será un sol amarillo con sombra y que marca la vida hasta lo más profundo ("al sol amarillo que traspasa las pieles marcando oscuras huellas"), que se acerca cada vez más a la irremediable noche:

“Un sol amarillo dejaba caer indiferente

pedazos luminosos de algo coloreado

más las sombras persistían

aún en los retazos del astro."

La infancia se pierde bajo un sol que ya se ha convertido en rojo ("Ajedrez"), y la aurora será anhelada debido al destino fatal y final de la poeta:

“1

entre los soplos de tantas arterias

hurgo agazapada en los bolsillos de mi campera

tratando de hallar algo que haga

flotar mi destripada

aurora"

El alba se convierte en un lugar alejado donde se ha quedado parte de la poeta y al que es imposible volver tras haber visto las sombras nocturnas. Allí dejará su cuerpo e intentará volver sin conseguirlo:

“He dado el salto de mí al alba.

He dejado mi cuerpo junto a la luz

y he cantado la tristeza de lo que nace."

"El alba la ha abandonado:

un golpe del alba en las flores

me abandona ebria de nada y de luz lila

ebria de inmovilidad y de certeza"

57 “Al producirse el exilio, la luz sufre una mutilación en su naturaleza absoluta y, a partir de esta, se convierte en su contrario: la luz mala, la luz pervertida, que, más que iluminar, conduce hacia la tiniebla" (A. Pizarnik, op. cit., 1975, 27). 
También el sol la abandonará; está fuera de él ("Yo no sé del sol"). A medida que avanza su obra, el sol pasa a ser símbolo de la muerte, y la noche será su único refugio en esta vida ("Tal vez la noche sea la vida y el sol la muerte"), tras haber desaparecido su infancia y también el amor:

“Recuerdo las negras mañanas de sol

cuando era niña

es decir ayer

es decir hace siglos"

"Sin ti

el sol cae como un muerto abandonado."

"Aun cuando el amado

brille en mi sangre

como una estrella colérica,

me levanto de mi cadáver

y cuidando de no hollar mi sonrisa muerta

voy al encuentro del sol."

Al final del camino los soles también serán negros ${ }^{58}$ (“Y hay, cuando viene el día, una partición del sol en pequeños soles negros."), la noche y el sol se fundirán en uno solo ("Desnudo soñando una noche solar") y el alba desaparecerá por completo:

"Alguien mide sollozando

la extensión del alba."

${ }^{58}$ Juan-Jacobo Bajarlía, en Anatomía de un recuerdo, recuerda sus inquisiciones junto a Pizarnik sobre Gerard de Nerval y sus poemas. Analizando uno de ellos Bajarlía nos explica: “También significa que Gerard de Nerval había perdido el optimismo, y la esperanza. Que ahora le era adverso el amor y la fe le era extraña. Había perdido todo lo que amaba. Su Estrella se había convertido en el Sol negro de la Melancolía, ese Sol inmortal grabado del Durero que tanto valía para combatir nostalgia como para hundirse en la desesperanza. [... ] Nuestra exégesis estaba en función directa con la vida trágica del poeta. No había para nosotros otra interpretación. Lo inconveniente de todo esto es que nuestra lectura impactaba a Alejandra" (Bajarlía, op. cit., 126127). 


\begin{abstract}
“Mañana
me vestirán con cenizas al alba, me llenarán la boca de flores."

El sol se ha transformado en un nuevo astro. Ya no es aquel sol amarillo de la infancia, sino el sol rojo del silencio bajo el que ya no viven las muñecas doradas (su infancia),
\end{abstract}

“Caen niñas de papel de variados colores. ¿Hablan los colores? ¿Hablan las imágenes de papel? Solamente hablan las doradas y de ésas no hay ninguna por aquí."

sino las palabras ("Al negro sol del silencio las palabras se doraban."), que ahora se convierten en los soles antes buscados y añorados:

"El soplo de la luz en mis huesos cuando escribo la palabra tierra. Palabra o presencia seguida por animales perfumados; triste como sí misma, hermosa como el suicidio; y que me sobrevuela como una dinastía de soles."

“Palabras emitidas por un pensamiento a modo de tabla del náufrago. Hacer el amor adentro de nuestro abrazo significó una luz negra: la oscuridad se puso a brillar. Era la luz reencontrada, doblemente apagada pero de algún modo más viva que mil soles."

En ese afán pizarnikiano de constante contradicción antitética, la luna se puede presentar también como elemento deseado de ese mundo en el que los demás viven, junto al sol, felices. Se trata de un mundo deseado que, de no faltarle palabras o poesía, podría haber sido un mundo feliz:

“QQué sé yo! ¡Faltan palabras, falta candor, falta poesía

cuando la sangre llora y llora!

¡Pudiera ser tan feliz esta noche!

Si sólo me fuera dado palpar

las sombras, oír pasos,

decir "buenas noches" a cualquiera

que pasease a su perro,

miraría la luna, dijera su

extraña lactescencia, tropezaría

con piedras al azar, como se hace." 
La poeta vive en la noche y en la muerte, y la luna se sitúa fuera de este mundo, en el mundo del sol y el alba, al que sólo puede llegar a través de la poesía. Le pide al poema que la traslade a ese mundo contrario al suyo, y por ello clama "Pero yo le ruego al poema, / yo le pido la luna al poema".

Pero la luna no puede conducirla a esa dicha. Es una luna que acompaña la soledad y la ausencia provocada por el miedo y el silencio: "Arpa de silencio / en donde anida el miedo. / Gemido lunar de las cosas / significando ausencia". La muerte es la consecuencia de esta desolación y entra en escena en la siguiente estrofa: "Espacio de color cerrado. / Alguien golpea y arma / un ataúd para la hora, / otro ataúd para la luz". El silencio es ahora lo único que queda; la soledad y la ausencia, compañeras inseparables, son las que conformarán el silencio deseado. Ni siquiera las palabras pueden ayudarla a salir de su cárcel: "Aún si digo sol y luna y estrella me refiero a cosas que me suceden. ¿Y qué deseaba yo? / Deseaba un silencio perfecto". En Pizarnik nada es casualidad, y mucho menos en la confección de su poesía. Los tres elementos que ahora provocan la desdicha y la infelicidad son los que producen luz en la noche mortal y anhelada. Quiere llegar al silencio, pero la luz de los astros todavía alumbra ese anhelo y no puede ser conducida a él.

La luz lunar será ahora, en lugar de portadora de dicha, la que la conduzca a la locura y la convierta en la "reina loca" de Lewis Carroll. La luna ya no es consuelo, es locura; y para ello alude a la necesidad lunar de uno de los personajes de Camus (Calígula, emperador loco que siempre pide y necesita la luna) como referencia en este poema: "Me digo: / Si me pide la luna es porque la /necesita. / Pero si (supongamos) le llevo la luna, / me dirá algo nada lindo de escuchar". El consuelo de la luz se ha perdido y sólo puede traer consecuencias funestas para la noche pizarnikiana.

En un sentido diferente del expuesto, la luna se convierte en símbolo de la duplicidad, de la desmembración y la desunión, debido a los diferentes costados de la luna, el que se ve y el oscuro; y a las cuatro fases lunares. Uno de esos costados es el funesto, aquel que no la deja vivir en la noche; pero el otro es el lado del amor, el que podría provocar el júbilo y el optimismo gracias a él. En "Más allá del olvido" escribe:

\section{MÁS ALLÁ DEL OLVIDO}

alguna vez de un costado de la luna

verás caer los besos que brillan en mí

las sombras sonreirán altivas

TRIANGLE 3 • March 2011 
luciendo el secreto que gime vagando

vendrán las hojas impávidas que

algún día fueron lo que mis ojos

vendrán las mustias fragancias que

innatas descendieron del alado son

vendrán las rojas alegrías que

burbujean intensas en el sol que

redondea las armonías equidistantes en

el humo danzante de la pipa de mi amor

Es ese costado oculto de la luna el que tal vez guarde el amor y los besos, las alegrías rojas (y no negras ni amarillas). Las cuatro fases de la luna representan la multiplicación de los yoes enunciativos de la poesía de Pizarnik, hasta tal punto que el mismo Octavio Paz, en su prólogo al libro Árbol de Diana, alude a la partición de su poesía como fundamento de ella misma: "Quizá se trata de una higuera mítica (la savia de las ramas tiernas es lechosa, lunar). El mito alude posiblemente a un sacrificio por desmembración: un adolescente (¿hombre o mujer?) era descuartizado cada luna nueva, para estimular la reproducción de las imágenes en la boca de la profetisa (arquetipo de la unión de los mundos inferiores y superiores)". Se descuartiza en cada luna nueva, cuando la luz hace mella en la oscuridad nocturna.

La estrella, símbolo que retiene su cualidad luminaria de fuente de luz, representa un astro de carácter celeste, de modo que pasa a ser símbolo de la espiritualidad.

La estrella hace su primera aparición en La tierra más ajena. Aquí se nos presenta como destino, como luz de vida, como aquella que se persigue sin cesar pero que es estrangulada por el tiempo y, por supuesto, por el sol, ya que la luz de éste hace que desaparezca la de la estrella, actúa como sombra (de nuevo el oxímoron) que la oculta:

“y el tiempo estranguló mi estrella

cuatro números giran insidiosos

ennegreciendo las confituras

y el tiempo estranguló mi estrella

caminaba trillada sobre pozo oscuro

los brillos lloraban a mis verdores

y yo miraba y yo miraba

y el tiempo estranguló mi estrella 
[...]

la sombra del sol tritura la esfinge de mi estrella

las promesas se coagulan

frente al signo de estrellas estranguladas

y el tiempo estranguló mi estrella

pero su esencia existirá

en mi intemporal interior

brilla esencia de mi estrella!"

Con este último verso la poeta increpa a su estrella para que exista, y existirá dentro de ella, de su poesía; es lo único que permanecerá imperecedero y aquello que el sol no podrá borrar ni ensombrecer. Es, por lo tanto, un símbolo positivo, de aquello que se quiere conseguir pero que nunca llegará ("a la estrella que se oculta cuando se la llama"), pero que es amiga y compañera de la noche, una noche en la que la poeta en ocasiones encuentra la paz y el sosiego tras la batalla constante de los mundos. Siempre va unida a la noche, pero, a diferencia de la luna, que no puede ser jamás compañera de la poeta, debido a su clara influencia del sol (sin él no puede existir), las estrellas actúan como signo nocturno que observan la noche y sus poemas: "La noche se astilló en estrellas / mirándome alucinada", "Poco sé de la noche / pero la noche parece saber de mí, / y más aún, me asiste como si me quisiera, / me cubre la conciencia con sus estrellas", estrellas mensajeras de la noche e invasoras de los poemas nocturnos que se identifican con todas sus características: "de estrella a estrella, / de sombra en sombra". No sólo acompaña a lo oscuro, sino también al amado, relacionándose de nuevo con esos factores que pueden provocar la placidez, como el amor: "Aun cuando el amado / brille en mi sangre / como una estrella colérica". Al final de su recorrido poético, la estrella pasa a formar parte del universo onírico de sus últimos poemas y, por lo tanto, se alía con el silencio y los jardines desolados:

“y finalmente

un himno sin desdicha

un sueño como una estrella

ebria del silencio

de los jardines abandonados 
mi memoria se abre y se cierra

como una puerta al viento"

En alguno de sus poemas más largos y prosaicos las estrellas se limitan a formar parte de esos escenarios encantados, sombríos, que envuelven los deseos de viaje y destrucción que se hacen patentes en algunos de sus textos: "Hombre destructor de tabúes y cielos estrellados", "Y una estrella dará color al ancla de plata que llevaba en su pecho. Tirar el ancla. Sí. Muy junto a ese barco gigante de rayas rojas y blancas y verdes... irse, y no volver".

Junto a las figuras del cielo y del sol aparece un personaje funesto que es el causante de la caída del cielo hacia la nocturnidad terrenal: el ángel. Al principio de su obra poética, este ángel será el culpable de la noche; él la ha llevado a la noche desde el sol, desde el cielo; es el culpable de su caída y de la pérdida de su inocencia:

"noche que te vas

dame la mano

obra de ángel bullente

los días se suicidan"

De esta forma, este ente sería el único capaz de hacer retornar de nuevo a la poeta al cielo, a Dios (aunque ya no sea mensajero de éste ${ }^{59}$ ), o también al otro mundo en el que el yo espera encontrar la dicha, la poesía:

“Sólo un ángel me enlazará al sol.

Dónde el ángel,

dónde su palabra.

Oh perforar con vino la suave necesidad de ser."

Ella se identifica con el ángel en varias ocasiones. En primer lugar, como ser que es incapaz de recordar lo perdido:

\footnotetext{
${ }^{59} \mathrm{Al}$ igual que en Rimbaud, "Esta altura, que es a la vez el abismo de la derrota 'manantial de fuego, donde mares y fábulas se encuentran', está poblada por ángeles. Pero los ángeles son puntos de luz y de intensidad, signos, que a un mismo tiempo relampaguean y se apagan, de aquella altitud, de aquella lejanía, de una inconcebible superabundancia; $\mathrm{y}$, a pesar de todo, son ángeles sin Dios y sin mensaje" (Hugo Friedrich, op. cit., 95).
} 
"De muerte se ha tejido cada instante.

Yo devoro la furia como un ángel idiota

invadido de malezas

que le impiden recordar el color del cielo."

Cuando la muerte se hace presente y se funde con el yo poético, el ángel es incapaz de volar; no hace más que tropezar con malezas que le impiden llegar al cielo clamoroso donde le espera el paraíso perdido. Es un ángel "idiota", porque no es capaz de cumplir su fusión salvadora. En segundo lugar, el ángel también puede presentarse como sujeto sin edad y sin nombre, forma angelical que se identifica con el propio yo, un sujeto poético que vaga por este mundo rutinario sin nombre y sin una muerte que la pueda salvar, un sujeto que cree ser ángel pero que en realidad no lo es y es por ello que sus "huesos lloran vagando":

"Esta manía de saberme ángel,

sin edad,

sin muerte en qué vivirme,

sin piedad por mi nombre

ni por mis huesos que lloran vagando."

Es el ángel amigo de la muerte; todo será muerte, si no se sabe volver al cielo de la infancia; la noche y el silencio asolarán la vida: "un agujero en la noche / súbitamente invadido por un ángel".

Todo es ángel. Todo es un intento de salir de la orilla de la muerte y de la noche para intentar volver a la etapa anterior a su caída ("Desde esta orilla de nostalgia / todo es ángel"), pero el ángel no puede cumplir su misión y se convierte en un ángel harapiento cansado de tanto intentar volar hacia las alturas inalcanzables. Se trata de un ángel que ha perdido sus ropajes y que ya no tiene ganas de luchar contra el viento destructor, un ángel vencido identificado con la constante lucha de la poeta por salir de la noche mortal:

\section{COMUNICACIONES}

El viento me había comido

parte de la cara y las manos.

Me llamaban ángel harapiento.

Yo esperaba.

El ángel ha muerto ("te abandonaron en posición de ángel petrificado") y se va deshaciendo de su realidad para pasar a formar parte de lo onírico y 
lo espectral; su forma se presenta desdibujada y vacía, transparente e irreal ("Y he bebido licores furiosos / para transmutar los rostros / en un ángel, en vasos vacíos"). Sólo el efecto del alcohol es capaz de transfigurar la realidad, pero tras su efecto los vasos quedan vacíos y todo vuelve a su cauce mortal. Los ángeles se aparecen en ensoñaciones irrealizables, inalcanzables y siempre unidos a la dicha que el yo poético desea, pero que se evapora, al igual que la imagen espectral del ángel:

“Una noche en el circo recobré un lenguaje perdido en el momento que los jinetes con antorchas en la mano galopaban en ronda feroz sobre corceles negros. Ni en mis sueños de dicha existirá un coro de ángeles que suministre algo semejante a los sonidos calientes para mi corazón de los cascos contra las arenas."

Este intentar elevarse hacia un cielo paradisíaco hace que el pájaro y todo lo que éste conlleva pase a ser símbolo del intento de ascensión para conseguir la salvación. Ya sea a través del mismo pájaro o a través de su jaula, sus alas, sus plumas $\mathrm{u}$ otros seres voladores, el alma pizarnikiana intenta, sin conseguirlo en ningún momento, ascender hacia la bóveda celeste y salvarse de la serpiente terrenal que ancla su alma a la realidad insoportable.

Para Chevalier, "El vuelo predispone a los pájaros a ser símbolos de las relaciones entre el cielo y la tierra. En griego el propio nombre es sinónimo de presagio y de mensaje del cielo. [...] En la misma perspectiva, el ave es la figura del alma escapándose del cuerpo, o solamente de las funciones intelectuales" (Chevalier, op. cit., 154).

Ya en su primera obra, La tierra más ajena, aparecen algunas incursiones del mundo de las aves en algunos poemas: "mis alas? / dos pétalos podridos", "pienso en tu rostro y en ti y en tus manos y /en el ruido de tu pluma y en ti / pero tu rostro no aparece en ninguna nube!". A pesar de ser uno de sus primeros poemas, se puede intuir ya el ansia y el anhelo de salvación de la poeta, que se ve frustrada desde un principio: no puede volar al cielo salvador, la caída es inminente, no es un pájaro ni un ángel; su única posibilidad de ascenso está "podrida", sin esperanza. En el segundo poema, "Cielo", que está dentro del apartado "Un signo en tu sombra", la pluma, la salvación, aparece ligada al amor; él es el único que posee la pluma, la capacidad de liberar el alma terrenal e intentar alcanzar el azul celeste, pero esta esperanza se ve truncada en el verso "pero tu rostro no aparece en ninguna nube!". 
En su siguiente obra, La última inocencia, al pájaro se le atribuye su simbología final: es el único que puede alcanzar la cima de la salvación volando y venciendo la destrucción de la pesadez terrenal. En el poema "Origen", este pájaro es capaz de "quemar" incluso a su mayor enemigo, el viento: "Los pájaros queman el viento / en los cabellos de la mujer solitaria".

Pero es en su tercera obra, Las aventuras perdidas, donde el pájaro alcanza su máximo esplendor en la producción de Alejandra Pizarnik. Ya el primer poema tiene un título simbólico: "La jaula", jaula en la que se halla encerrada el alma poética, acompañada de la sombra y de la muerte. "Afuera hay sol", afirma en el primer verso. Ella está rodeada de un infierno dorado que no le permite ascender a la felicidad. No puede volar, ${ }^{60}$ pues la destrucción y la muerte son sus únicas compañeras:

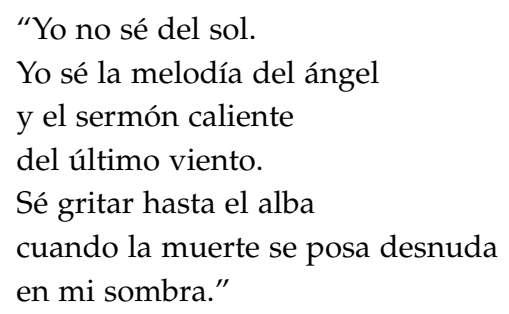

Esta jaula no es sólo encierro, sino también protección, ya que la salvaguarda del día luminoso.

Pero el pájaro vuela a través de todos los poemas de esta obra. En "Tiempo", la felicidad que conllevaría sentirse pájaro, es decir, desprenderse de todo lo tangible y mundano, viene asociada con la inocencia infantil, universo inocente en el que el alma vive desconocedora de la pesadumbre terrestre: "Mi infancia y su perfume / a pájaro acariciado". Como ya hemos explicado, el pájaro, libertad infinita, no sólo va ligado al concepto de inocencia, sino también al del amor, el amor como sentimiento sublime que ayudaría a elevar el alma perdida en los suburbios de la tierra. Así nos lo confirma el poema "Luz caída de la noche":

“pero quiero ser del pájaro enamorado

que arrastra a las muchachas

60 “Al igual que en el caso del viento, la caída determina que esa forma absoluta del pájaro muera, [...] A partir de esta experiencia de entrada en la temporalidad y la espacialidad desacralizadas, la imagen del pájaro quedará, ya como testimonio de la criatura cercenada en sus atributos totales" (Piña, op. cit., 1981, 23). 
ebrias de misterio

quiero al pájaro sabio en amor

el único libre"

"Pero un pájaro muerto / vuela hacia la desesperanza", no conseguirá nunca llegar a su destino, ya que la muerte y el vacío lo inundan todo: "Un pájaro muerto llamado azul". La mudez y el vacío se apoderan de sus versos; ya no entiende al pájaro, sus esperanzas se destruyen por momentos y su soledad es la única que la acompaña, tal vez sea la salida a su intensa búsqueda de liberación:

\section{“La carencia}

Yo no sé de pájaros,

no conozco la historia del fuego.

Pero creo que mi soledad debería tener alas."

"¿A qué, a qué

este deshacerme, este desangrarme,

este desplumarme, este desequilibrarme

si mi realidad retrocede

como empujada por una ametralladora

y de pronto se lanza a correr,

aunque igual la alcanzan,

hasta que cae a mis pies como un ave muerta?"

Se despoja de cualquier resquicio, de cualquier pluma de anhelo y esperanza de salvación que pueda haber quedado a lo largo de ese intento de ascensión a la inocencia perdida; se siente abandonada, y la ausencia de un ser que pueda proporcionarle un sentido vital hace que el delirio y la locura se aposenten de nuevo en sus venas:

"La sangre quiere sentarse.

Le han robado su razón de amor.

Ausencia desnuda.

Me deliro, me desplumo.

¿Qué diría el mundo si dios

lo hubiera abandonado así?" 
Ese intento de ascensión no se representa sólo mediante el vuelo de un ave; también su poesía, mediante las metonímicas plumas, intenta acercarse al vuelo con su consecuente caída inevitable:

“¿Y quién no tiene un amor?

¿Y quién no goza entre amapolas?

¿Y quién no posee un fuego, una muerte,

un miedo, algo horrible,

aunque fuere con plumas,

aunque fuere con sonrisas?"

En uno de los últimos poemas de esta obra, llega el momento en que la jaula se convierte en pájaro y el caos y el desorden vuelven loca al alma poética. El alba desaparece y la muerte y la sombra lo impregnan todo con su oscuridad. El pájaro es a su vez la jaula y la jaula el pájaro; no se puede hallar ya consuelo en ninguna de las esperanzas que quedaban:

"Señor

La jaula se ha vuelto pájaro

y se ha volado

y mi corazón está loco

porque aúlla a la muerte

y sonríe detrás del viento

a mis delirios

Qué haré con el miedo

Qué haré con el miedo"

En sus primeros textos también se presentan otros animales que tienen la capacidad de volar y que representan todo aquello que el yo poético no puede conseguir. En el poema "A la espera de la oscuridad", las golondrinas y las mariposas simbolizan la primavera perdida, la inocencia y la infancia que han dejado de formar parte del alma poética para pasar a formar parte de la muerte de las muertes:

“Ampáralo niña ciega de alma

Ponle tus cabellos escarchados por el fuego

Abrázalo pequeña estatua de terror

Señálale el mundo convulsionado a tus pies

A tus pies donde mueren las golondrinas 
Tiritantes de pavor frente al futuro

Dile que los suspiros del mar

Humedecen las únicas palabras

Por las que vale vivir

Pero ese instante sudoroso de nada

Acurrucado en la cueva del destino

Sin manos para decir nunca

Sin manos para regalar mariposas

A los niños muertos"

En su segunda etapa poética, la presencia del pájaro se acentúa. El pájaro ya no vive; las palabras han pasado a ocupar el espacio de la supervivencia y son ellas las únicas que pueden resucitar el canto del pájaro. Es el canto del pájaro a través de las palabras lo único que queda de él; la poesía es la única solución: "Estos huesos brillando en la noche, / estas palabras como piedras preciosas / en la garganta viva de un pájaro petrificado". Tan sólo la garganta como órgano reproductor de sonidos vocales, y por lo tanto de palabras, se ha salvado de la muerte petrificada. Los pájaros son ya elementos irreales; no vuelan a pesar de los intentos del yo de confeccionarles ${ }^{61}$ unas alas que puedan alejarlo de este mundo: "has emplumado tus pájaros".

El pájaro ya está fuera de su alcance y lo único que ella puede hacer es mirarlo a través de una barrera infranqueable:

\section{ANTES}

bosque musical

los pájaros dibujan en mis ojos

pequeñas jaulas

Los pájaros le recuerdan, pues, que ella ya no puede salir de su jaula, y se lo dicen tatuando una jaula prisionera en sus ojos, en su alma. Están siempre contenidos por algún elemento que los separa de donde está el yo lírico: "Grises pájaros en el amanecer son a la ventana cerrada lo que a mis males mi poema". Mediante esta regla, la exclusión que conlleva la ventana cerrada para los pájaros ya grises que quieren entrar significa lo mismo que la barrera de sus poemas para sus males: algo infranqueable y en lo

\footnotetext{
${ }^{61}$ Recuérdese el mito de Dédalo e Ícaro, en el que confeccionan unas alas para poder huir del laberinto de Creta.
} 
que cobijarse para no dejarlos pasar. Aquí los pájaros ya son grises, pues el sujeto lírico ha encontrado una morada mejor que el cielo para poder crearse: el lenguaje. Pero esta pequeña tregua está destinada a desaparecer; el pájaro está condenado a morir, al igual que la poeta. La destrucción es inevitable:

“Y pienso en el viento que viene a mí, permanece en mí. Toda la noche he caminado bajo la lluvia desconocida. A mí me han dado un silencio pleno de formas y visiones (dices). Y corres desolada como el único pájaro en el viento."

\section{Naturaleza ensoñadora y destructiva}

En Pizarnik, la naturaleza sirve para indicar estados psicológicos, sueños, ensueños. Esos estados pueden ser de alegría o de terror. A través de su poesía tomará de los referentes externos —viento, lluvia, sol, pájaros, paisajes, jardín - lo que simbolice para ella un estado de alma. Adjudicará a estos signos cualidades no poco terribles; los hará suyos, imbricándolos en su poesía como personajes, creando campos semánticos que nos llevan a paisajes extraños y maravillosos, o terribles, que tienden a obstruir la realidad cotidiana. La naturaleza se utiliza sólo en función de situaciones subjetivas. Dirá la palabra, el signo, que siempre significará otra cosa: "Aún si digo sol y luna y estrella me refiero a cosas que me suceden". Y luego dirá: "Y el jardín de las delicias ${ }^{62}$ es el verdadero jardín, que es siempre otra cosa".

La lluvia se presenta como un ser invisible, al igual que el viento que camina entre el cielo y la tierra, entre ambos mundos. Su significado es el de la destrucción, puesto que es un fenómeno natural que puede interrumpir el ascenso al cielo y provocar la caída de nuevo en el infierno terrenal. Sin embargo, en algunas ocasiones simboliza lo misterioso o benéfico:

Como la luz y la oscuridad, la lluvia y el viento colman el espacio, pero además lo ponen en movimiento. La lluvia es un desplazamiento vertical

\footnotetext{
${ }^{62}$ Algunos paisajes de la poesía de Pizarnik se estructuran "como cuadros dinámicos que no por azar recuerdan pinturas surrealistas o las de su admirado Hyeronimus Bosch, a cuyo 'jardín de las delicias' alude varias veces en sus textos. Estos paisajes están constituidos por elementos simbólicos, entre ellos también cuadros pintados, de fluidas fronteras con lo 'real' de la escena" (Goldberg, op. cit., 53).
} 
que trae desde arriba un mensaje misterioso y benéfico. [... ] En otros casos, la lluvia llena el espacio de fuerzas hostiles o destructivas.

\section{F. Goldberg, op. cit., 60}

Ya en sus primeros textos la lluvia se nos muestra bajo este aspecto: "la luna odiada que da luz a mi espesa cabeza cortada a la navaja / [... ] que da luz a los vientos brutales / [...] a la lluvia húmeda contoneándose en su desnudez repulsiva". Le repulsa la pureza de su intimidad y la sencillez transparente de su destrucción; quiere vengarse de ella, al igual que del viento: "El frío / pagará. Pagará el viento. La lluvia pagará. / Pagará el trueno". Pero no podrá librarse de ella y sufrirá el tormento que otros ya han sufrido: "Que nada es posible ya lo sabían los que inventaban lluvias y tejían palabras con el tormento de la ausencia".

En sus obras fundamentales, la lluvia provoca una catástrofe desoladora y, además, se convierte en espacio esencial del paso del tiempo. Los pájaros, queriendo ascender de nuevo, se ven ultrajados por esta agua que moja sus plumas y les impide volar hacia la libertad celeste:

"Son mis voces cantando

para que no canten ellos,

los amordazados grismente en el alba,

los vestidos de pájaro desolado en la lluvia."

Mediante la metáfora de esta libertad ansiada a través de unos vestidos de pájaros (no son pájaros de verdad, todo es una ilusión), el deseo se desvanece a causa de una lluvia devastadora que arrasa con sus sueños. No sólo la lluvia y el viento son capaces de destrozar la esperanza de salvación del pájaro, sino que, cuando el sujeto poético encuentra una salida en las palabras con la consecuente fusión en ellas, la lluvia aparece con su caos y arrasa el poema y el fuego de la creación:

\section{MADRUGADA}

Desnudo soñando una noche solar.

He yacido días animales.

El viento y la lluvia me borraron

como a un fuego, como a un poema

escrito en un muro. ${ }^{63}$

${ }^{63}$ Se vuelve a fusionar en este verso la arquitectura del poema, un poema que se construye como cualquier objeto, como un cuadro, y que se puede trastocar, transformar o reordenar de forma no sólo conceptual, sino también visual. 
Esta imagen de desolación a causa de su desaparición en un muro se vuelve a repetir de nuevo en "Caminos del espejo": "Como una niña de tiza rosada en un muro muy viejo súbitamente borrada por la lluvia".

Su alma está abatida y la lluvia actúa como tortura constante, gota a gota, minuto a minuto, como si de un canto mortal se tratase, espacio ideal del paso del tiempo. La lluvia se identificará con otros elementos de destrucción, además del viento. En sus primeros poemas, donde el sol y su luz no dejan vivir a la poeta, la lluvia aparece como un elemento más de la agonía solar:

“Montañas vibrantes de cercanía solar, de lluvia inaudita, de flores invisibles posibles de crear bajo tanto cielo, tanta lumbre cromática, tanta conjetura de lugar."

Si avanzamos en su poética, en las obras previas a su muerte, el sol se ha convertido en música. Ahora es la música la que acecha la paz que le produce el silencio; y la lluvia, debido a su inestimable relación con las notas musicales y sus consecuencias funestas, aparece interrelacionada con ella: "de música la lluvia / de silencio los años". Esta lluvia sigue acompañando siempre al silencio: "Toda la noche he caminado bajo la lluvia desconocida. A mí me han dado un silencio pleno de formas y visiones (dices)".

La desintegración es tal que la lluvia llegará a identificarse con la muerte y con todo lo que puede llevar a ella, como el viento o la música infernal: "La música es amiga del viento / amigo de las flores / amigas de la lluvia / amiga de la muerte". Mediante la anáfora de términos derivativos de la palabra primitiva "amigo" se establece una serie de estructuras paralelas que encadenan unos términos con otros, relacionándose en forma de gradación, pero esta gradación acaba en una identificación de significados con el último término "muerte". De esta forma, todo lo que ha provocado soledad, desolación, destrucción, alienación y ruina acaba convirtiéndose en muerte, muerte que en algunas ocasiones es repudiada (sobre todo en sus primeros textos), y en otras, añorada y deseada (esta ambigüedad se repite a lo largo de toda su producción). Ahora la lluvia también puede ser un marco donde se desenvuelve lo buscado, donde el silencio pueda desarrollarse gracias a su intervención: "lluvia sola en mi silencio de fiebres", "Tantas criaturas ávidas en mi silencio / y esta pequeña lluvia que me acompaña". 
El viento supone un nuevo elemento natural de destrucción, ${ }^{64}$ ya que vuelve a interponerse entre los dos mundos, el terrenal y el celeste, y es el que azota el vuelo del pájaro, la libertad ascensional que el yo desea y que no se puede llevar a cabo debido a la fuerza que el viento arrasador produce en su poesía.

El viento es destrucción, y en ocasiones irá acompañado de elementos negativos, e incluso antitéticos, como "viento negro" o "la luz del viento". Es incluso capaz de acabar con las salvadoras palabras: "Alguna palabra que me ampare del viento", y la ha dejado destrozada de tanto azotarla. Las consecuencias de este viento hacen que su cuerpo acabe desmoronado y sin sentido; sus huesos, su cara, acaban roídos por la acción enloquecedora de un viento irracional que no deja que la salvación se lleve a cabo, de forma que acaba siendo un cuerpo de huesos rotos:

“has construido tu casa

has emplumado tus pájaros

has golpeado al viento

con tus propios huesos"

"El viento me había comido

parte de la cara y las manos."

Pero es su destino y lo acepta ("Dibujé mi itinerario / hacia mi lugar al viento."), a pesar de que el choque contra el muro transparente pero indestructible que representa lo destruya "todo"; "Un viento violento arrasó todo".

De la misma forma que la lluvia, el viento se va a identificar con la muerte, pasando a un plano en el que la negatividad del término se hace menos plausible, debido a la contradicción que la muerte supone dentro de

64 "Debido a la agitación que lo caracteriza es símbolo de la vanidad, de inestabilidad y de inconstancia. Es una fuerza elemental, que pertenece a los Titanes: basta con citar a la vez su violencia y su obcecación" (Chevalier, op. cit., 1070). Pese a que Chevalier no lo indica, debe recordarse que, a propósito de la Historia de la Fundación del Real Monasterio de El Escorial, Fray José de Sigüenza afirma: “No llamó San Pablo a Satanás (Epr. 6-10) príncipe de las potencias del viento? ¿Y no hay en las cuatro esquinas del claustro de Silos cuatro columnas con los capiteles esculpidos de redes, como cepos armados o conjuros contra la asechanza diabólica del Viento?" (Cf. Rafael Sánchez-Mazas, "El viento en El Escorial", en Las aguas de Arbeloa, Madrid, Trieste, 1983, 115-116). 
la poética pizarnikiana. En el poema "Origen" incluso llega a decir: "Hay que salvar al viento", afirmación que se repite, al principio y al final, como si el origen y el final de la vida del yo poético dependieran de éste. El viento, como hemos dicho, será su destino y nada podrá cambiarlo. En uno de sus poemas de Las aventuras perdidas se autodenomina "Hija del viento"; con este poema se inicia la fusión del sujeto lírico con el viento, de forma que éste vivirá en él y pasará a ser parte inseparable de su construcción poética: "Tú haces el silencio de las lilas que aletean / en mi tragedia del viento en el corazón.", "Me olvidé. Adentro el viento. Todo cerrado y el viento adentro.", "Y pienso en el viento que viene a mí, permanece en mí". El viento, al igual que los "pájaros grises" cuya ventana es el muro contra el que chocan, se encierra dentro de ella y llena su ser de muerte: "Como el viento sin alas encerrado en mis ojos / es la llamada de la muerte". Intervienen de nuevo los ojos como ventana que da al exterior y por donde penetra la destrucción de la realidad del mundo circundante, ojos que, tras ver lo que hay enfrente, sólo pueden albergar soledad y destrucción interior.

Otro de los espacios simbólicos que conforman la naturaleza poética pizarnikiana es el bosque ("lugar donde florece abundante la vida vegetal, no dominada ni cultivada, y que oculta la luz del sol, resulta potencia contrapuesta a la de éste y símbolo de la tierra"), un espacio pizarnikiano en el que se recogen los instintos más animales y que contribuye a la elaboración de la simbología de la muerte o del silencio. En algunas ocasiones incluso llega a ser el espacio poético donde el yo elabora la poesía sustituyendo a la noche en alguna ocasión. Es un bosque oscuro, ${ }^{65}$ que no deja penetrar ningún tipo de luz y siempre está acompañado de la violencia y la destrucción de los instintos, de las pasiones e incluso del viento. "Mi bosque" (título que englobaría todas estas afirmaciones) guarda en su interior la ingratitud de las plantas, de los caballos indomables y del viento negro, y se convierte en el espacio en el que la poeta "redondea versos":

\section{BOSQUE}

acumular deseos en plantas ingratas referir lo tuyo

${ }^{65}$ Cfr. Friedrich Hölderlin, “Cuando del cielo...", Poemas de la locura, Madrid, Hiperión, 2005, 102-105. Además del "oscuro bosque", este poema está realizado sobre una base simbólica natural en la que aparecen el cielo, el río y el bosque, coincidiendo con Pizarnik en su inclusión aunque no en su significado en algunas ocasiones. 
en verdor solemne

y entonces vendrán diez caballos

a tirar la cola al viento negro

moverán las hojas

sus crines mojadas

y vendrá la escuadra

redondeando versos

Llegará a identificarse con la noche como espacio poético de soledad ("un puro errar / de loba en el bosque / en la noche de los cuerpos" o "lo que yo quise decir en noches variadas como los colores del bosque"). Es un bosque que, en sus últimos textos, se identifica con el miedo, con la musicalidad que le impide oír el silencio:

\section{ANTES}

\section{a Eva Durrell}

bosque musical

los pájaros dibujan en mis ojos

pequeñas jaulas

Pero ante todo será el lugar por el que la soledad y la incomunicación vagan, convirtiéndolo en un "bosque hecho cenizas", en el que "no he cesado de morar".

Los cuatro elementos (agua, fuego, tierra y aire) también conforman el universo poético, como en "Aproximaciones":

"no lejos del alba nace el día

visión de las últimas flores

la luz gira en mi rostro que esperaba

las nupcias de los cuatro elementos"

En ese universo representan el mundo inalcanzable que baña el sol con su luz, aquel mundo que nace al alba y en el que las flores se abren con el calor que irradia el sol, aquel mundo al que en sus primeros textos desea regresar, pero que en los últimos constituye la otra orilla, a la que no quiere viajar. También pueden ser los elementos que conforman la naturaleza (fuego, mundo vegetal, mundo animal y seres inertes), como se nos presenta en el poema "Salvación": 


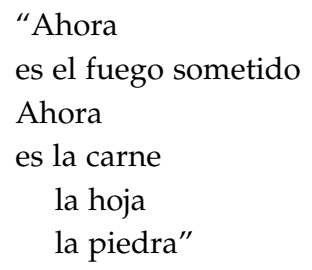

De esta forma anafórica, el fuego de la creación se identifica con el mundo en todos sus contextos; es la propia poeta la que puede crear este nuevo mundo y todos los elementos que son necesarios para conformarlo; es a través de la poesía que el sujeto lírico crea un nuevo mundo en el que vivir, y no sólo lo hace a través de la anáfora y el paralelismo sintáctico, sino que la disposición espacial iguala los tres elementos naturales que se identifican con el ardor creativo representado en el fuego.

Según Cirlot, el fuego es considerado por "los alquimistas como 'agente de transformación', pues todas las cosas nacen del fuego y a él vuelven. Es el germen que se reproduce en las vidas sucesivas [...]. En este sentido de mediador entre formas en aparición y formas en creación, el fuego se asimila al agua, y también es un símbolo de transformación ${ }^{66}$ regeneración" (Cirlot, op. cit., 215).

Para la poeta, este fuego es la dicha de la creación; se siente creadora de "un fuego secreto"; siente dentro una creación que se nos presenta sincera, bien escrita e innata:

“millares de montañas

revientan exquisitas

delante del sol rojo

(no sol amarillo)

pensar innato en moldeadas rejas"

Dentro de su primera obra dedica dos poemas a este aspecto. El primero de ellos, "Días contra el ensueño", es una especie de poética en la que Pizarnik, mediante la negación continua de todos los versos, nos revela lo que será su poesía en el resto de su obra. Actúa a modo de prólogo metodológico y metapoético. Ella no quiere "blancos rodando", es decir,

\footnotetext{
${ }^{66}$ En el proceso alquímico, tal y como indica Burckhardt, el "fuego secreto" es el elemento imprescindible para unir el mercurio con el azufre, siendo el primero el símbolo de la continuidad psíquica en el tiempo" (véase para este aspecto, AA. VV., El libro de la alquimia, Barcelona, Ciencias Ocultas y Misterios, 1991, 105-108, passim).
} 
palabras sin sentido conceptual, sino simplemente estéticas; "voces robando", integrar en su poesía características, elementos o versos ya escritos, o "tocar abstractos", pasar al plano concreto los sentimientos abstractos de la vida.

Con los dos últimos versos concluye toda su teoría. La poesía ha de ser caótica y ha de expresar caos; el lector debe recomponer sus valores principales a través de una poesía conceptual y caótica, una poesía que deja a un lado las palabras gastadas por el uso repetitivo de los poetas: "No querer traer sin caos / portátiles vocablos".

La dicha creativa, la posesión de una idea original y única, se hace latente en el poema "Poema a mi papel". Ya el título nos induce a pensar en lo importante que será la poesía y la creación única dentro de esta obra y de su vida. Es un conjunto de versos dedicado en su totalidad al orgullo poético por poseer ese genio innato en ella:

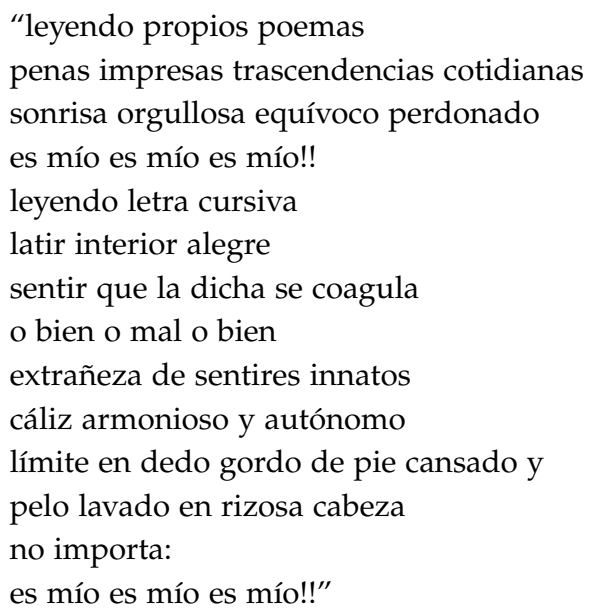

Hace aquí una enumeración caótica de lo que son sus "propios poemas". Para ella son "trascendencias cotidianas", pues sus poemas introducen continuamente elementos de la vida diaria; "sonrisa orgullosa", se siente creadora de algo que nadie más puede hacer, y está orgullosa de poder hacerlo y de poder trasmitirlo; "latir interior alegre", es lo que le da la vida, lo único que hace que su corazón lata; "extrañeza de seres innatos", su romanticismo desatado le hace pensar en la poesía como algo innato en el poeta, y "cáliz armonioso y autónomo": la poesía es sagrada y vital como 
el cáliz que da la vida, pero es autónoma. El genio creador sólo es suyo, sólo lo puede poseer ella; sus límites son su dedo gordo del pie y su cabeza.

Este don innato la hace sentir viva, "la dicha se coagula"; pero, mediante la repetición de los versos 4 y 14, Alejandra nos deja claro que esa capacidad creadora, ese don, "es mío es mío es mío!!"

Encontramos otras referencias en otros poemas de la obra. En el poema "Noche" nos habla de "creación sincera en surco capilar", y en el poema "Dibujo" nos dice que "huele primores bien escritos".

La poesía y este genio creador es lo que le da la vida. La creación y su preocupación por la perfección lingüística van a regir toda su poesía posterior. Ya en este poema hace una breve alusión a lo que será su posterior poesía. Afirma en un solo verso que el lenguaje va a ser el elemento constitutivo de su vida; lenguaje y vida se van a identificar, y ya aquí expresa ese deseo: 67

“quisiera ser masa lingüística

para cortarle la barba

ondas en preciosa lumbre

alzar bandera gratuita

kilómetros de nueces

y golpes en relevante torniquete."

Alejandra corregirá y revisará constantemente sus poemas para alcanzar la perfección lingüística, cortará "barba" y la quemará, para poder así "alzar bandera gratuita", pureza lingüística.

De esta forma abre el camino a la insistente preocupación por la perfección del lenguaje, idea recurrente y obsesiva en el resto de su producción poética.

El fuego es el símbolo que representa este júbilo del lenguaje creado. La filiación del poema con el fuego es constante hasta que las palabras dejan de ser su refugio y el silencio pasa a ocupar su lugar:

${ }^{67}$ Este intento de identificación, finalmente imposible, arroja la poética pizarnikiana a la estirpe romántica, dado que afirmamos con Gadamer: "El ser que puede ser comprendido es lenguaje", y así lo que "es" "nunca se puede comprender del todo"; de ahí que tal afirmación signifique "para la conciencia romántica que el lenguaje nunca alcanza el misterio último e indescifrable de la persona individual" (Cf. Hans-Georg Gadamer: "Texto e interpretación” (1984), en Hermenéutica, José Domínguez Caparrós (ed.), Madrid, Arco/Libros, 1977, 77-82). 


\section{QUIEN ALUMBRA}

Cuando me miras

mis ojos son llaves,

el muro tiene secretos,

mi temor palabras, poemas.

Sólo tú haces de mi memoria

una viajera fascinada,

un fuego incesante.

En "Quien alumbra", las palabras chocan contra el muro del miedo en uno de sus múltiples sujetos, pero es ella "la viajera", la que parte en busca de un mundo nuevo, la que logra salvarse a través de la poesía, a través del "fuego incesante" en que se trasforma. Pero el viento y la lluvia acabarán con este afán de traspasar los muros de la decadencia para salir al sol: "El viento y la lluvia me borraron / como a un fuego, como a un poema / escrito en un muro". El poema ya no es posible, puesto que el fuego ha sido apagado por los dos agentes que ejercen en él fuerzas contrarias, lo reavivan y lo apagan con su agua. Lo único que queda tras la pérdida de las palabras es el silencio:

\section{Signos}

Todo hace el amor con el silencio.

Me habían prometido un silencio como un fuego, una casa de silencio.

De pronto el templo es un circo y la luz un tambor.

Es esta llama que da vida la que ahora, en vez de hacerlo mediante las palabras, acaba engendrando silencio: "El lenguaje silencioso engendra fuego. El silencio se propaga, el silencio es fuego".

Por otro lado, la piedra no será símbolo de lo inerte y sin vida. "En la tradición, la piedra ocupa el lugar de calidad. Existe entre el alma y la piedra una relación estrecha, La piedra y el hombre presentan un doble movimiento de subida y de bajada. [...] La piedra bruta desciende del cielo; transmudada, se eleva hacia él. [...] Las piedras no son masas inertes; piedras vivas caídas del cielo, permanecen animadas tras su caída" (Chevalier, op. cit., 827-828), pese a que en la tradición humanística cristiana los minerale ocupen en la scala perfectionis el último lugar, pegados a la tierra, como el 
acédico en su correspondencia, según la visión humanista del mundo, por ejemplo, de Charles de Bouelles. ${ }^{68}$

Es por ello que en muchos de sus textos se identifican con los ojos y se relacionan con cualquier elemento vinculado a ellos. En La tierra más ajena afirma: "mis pupilas oscuras piedras caídas". La vida celestial ha desaparecido de sus ojos; ya no albergan ningún tipo de esperanza, y las piedras, al caer desde el cielo, han perdido su vida y se identifican con la propia poeta. Lo único que pueden hacer estas piedras es llorar, como indica el título del poema "Balada de la piedra que llora" o como ocurre en el poema "La caída", donde sus ojos de piedra sólo pueden llorar junto al silencio, un silencio que se advierte como objetivo y destino:

"Yo no sé. No sé sino del rostro

de cien ojos de piedra

que llora junto al silencio

y que me espera."

Estas piedras, cuando no se identifican con sus ojos, la asfixian ("piedras opresoras / que duermen en la garganta") o impiden que su viaje hacia la otra orilla del mundo, donde se encuentra la dicha, pueda llegar a buen fin ("ellas me desposeen / hacen de mí un barco sobre un río de piedras"), o simplemente se alían con la noche y con el silencio para que el dolor de la caída descanse en un espacio poético:

35

Vida, mi vida, déjate caer, déjate doler mi vida, déjate enlazar de fuego, de silencio ingenuo, de piedras verdes en la casa de la noche, déjate caer y doler, mi vida.

Pero es en sus dos últimos libros, Extracción de la piedra de locura y El infierno musical, donde la piedra pasa a ser el elemento esencial de su poesía más caótica, aquella que se disuelve en el onirismo y las imágenes mortales, destructivas, morbosas y violentas. Dos de esos poemas largos llevan en su título dicho elemento: "Extracción de la piedra de locura" y "Piedra fundamental".

\footnotetext{
23.

${ }^{68}$ Véase para este aspecto, Peter Burke, El Renacimiento, Barcelona, Crítica, 1993,
} 


\section{Animales en la noche}

El lobo ${ }^{69}$ (o la loba, cuando el sujeto poético se funde con ella) aparece siempre relacionado con la noche o el bosque, espacio natural y real en el que sobrevive. En la noche, la loba vaga por sus caminos buscando una salida a su dolor y a su soledad: "he sido toda ofrenda / un puro errar / de loba en el bosque / en la noche de los cuerpos". Es una más de sus voces desoladoras, una "máscara de loba" que se equipara con la noche ("La noche tiene forma de un grito de lobo") y que acabará asociándose con la muerte inherente de sus últimos textos, en los que el caos, el sueño destructor y la violencia de los sintagmas y de las imágenes dementes y terroríficas se hacen patentes: ${ }^{.0}$ "y los troncos son cabeza vestidos de colores tan alegres danzaban rondas infantiles junto a un ataúd lleno de cabezas de locos que aullaban como lobos".

Esta loba sólo es capaz de relacionarse con la lluvia y el viento, con todo aquello que provoca la destrucción. También puede ejercer de madre, aunque sus vástagos heredarán su condición de loba nocturna sola y desamparada del mundo de la luz, donde sólo unos cirios casi imperceptibles iluminan una tierra de "pestes y plagas":

"La razón me muestra la salida del escenario donde levantaron una iglesia bajo la lluvia: la mujer-loba deposita a su vástago en el umbral y huye. Hay una luz tristísima de cirios acechados por un soplo maligno. Llora la niña loba. Ningún dormido la oye. Todas las pestes y las plagas para los que duermen en paz."

El lobo es la muerte y vive en la noche ("Estoy triste en la noche de colmillos de lobo"). El lobo se vuelve así gris, un lobo que ronda ahora una ciudad desolada en la que están todos muertos y ninguna esperanza es posible ya: "Mi muerte... el lobo gris... la matadora que viene de la lejanía... ¿No hay

69 “Este monstruo deberá romper también esta cárcel en el crepúsculo de los dioses, es decir, al fin del mundo, y devorar al sol. El lobo aparece aquí como un símbolo del principio del mal, en un orden de ideas que no deja de tener relación con la cosmogonía gnóstica. [...] También tiene conexión el mito con todas las ideas de aniquilamiento final de este mundo, sea por el agua o por el fuego" (Cirlot, op. cit., 286-287).

70 “Luego se intensifica bajo el investimiento del símbolo de 'la loba', que vigoriza semánticamente la carga metafórica, religándola a una simbología que remite a la ferocidad y carnicería salvaje" (Ana María Rodríguez Francia, op. cit., 180). 
un alma viva en esta ciudad? Porque ustedes están muertos. ¿Y qué espera puede convertirse en esperanza si están todos muertos?".

Al igual que el lobo, el perro representará el sonido y los ladridos; también el yo poético se identificará con él y aparecerá en muchas ocasiones con connotaciones negativas relacionadas con la muerte o la música.

En sus primeros textos aparecen junto a los gatos, formando parte de un paisaje de lluvia en el que el "cielo gime" y el juego se deshace: "tremendo espesor de perros y gatos / las gotas gimen". Aunque muchas veces el perro representará lo cotidiano ("decir 'buenas noches' a cualquiera / que pasease a su perro", "un perro se arrastra, una pareja de enamorados se pasea despacio bajo la lluvia"), en la mayoría de los casos está relacionado con la muerte o con cualquier símbolo negativo de los que hemos ido hablando.

En "Un sueño donde el silencio es de oro" el perro se asocia con el invierno y también con la muerte: "El perro del invierno dentellea mi sonrisa. Fue en el puente. Yo estaba desnuda y llevaba un sombrero de flores y arrastraba mi cadáver desnudo y con un sombrero de hojas secas". El perro se ha convertido aquí en frío invernal y es capaz de "dentellear" la sonrisa de la poeta procurando que, como consecuencia, su cadáver aparezca y se muera todo lo que había en él, incluso las flores de su sombrero. Son perros desconsoladores que atacan cualquier resquicio de esperanza que pueda quedarle al yo poético:

“La luz del lenguaje me cubre como una música, imagen mordida por los perros del desconsuelo, y el invierno sube por mí como la enamorada del muro."

Es la mordedura del perro la característica funesta que domina la escritura y la convierte en música desconsoladora. El perro se identifica de nuevo con el invierno y el frío, que son los que provocan la soledad al arrebatarle ese "muro" en el que el lenguaje se propaga a modo de salvación. Los perros no la abandonarán; es el "perro de maldoror", 71 aquel que consigue

\footnotetext{
${ }^{71}$ En el poema "En esta noche, en este mundo" aparece una clara referencia al perro que Isidore Ducasse, Conde de Láutreamont, definía como perro "con ansias de infinito". La estrofa del poema pizarnikiano dice así:

"V

y el perro de maldoror

en esta noche en este mundo
}

TRIANGLE 3 • March 2011 
alcanzarle a todas horas, en cualquier momento, el que se convierte en su sombra:

"Como dados rodando premeditadamente

Como dedos de muerto pulsando la sola cuerda de un arpa

Como alas pesadas cuando sueño que duermo con los ojos abiertos

Como el sol que se ensombrece en mi mirada

Como la oscuridad desunida en toda la noche de mi vida

Como los perros de mi sombra"

Mediante la cascada propia de la propuesta del automatismo bretoniano y la conocida fórmula "Il beaux comme...", se construye la poética maldita de Pizarnik. Se nos enumeran aquí varios de los elementos que construyen la poética maldita de Pizarnik: la mala suerte, los muertos, las alas, el sol, la noche, los perros y la sombra.

\section{El universo cromático ${ }^{72}$}

Muchos son los colores que aparecen a lo largo de la obra pizarnikiana. A continuación se analizan los más destacados.

donde todo es posible

salvo

el poema"

${ }^{72} \mathrm{El}$ universo cromático en la poesía pizarnikiana despliega su carácter simbólico desde diversas perspectivas. Si, por un lado, el color, desde la lección simbolista y posteriormente "fauvista", no viene de la naturaleza, sino que va hacia ella, mediante un sistema de transposiciones cenestésicas y sinestésicas -verde viento-, por otro, junto a los demás elementos, se instaura en la tradición lírica de los repertorios petrarquistas (cfr. María Pilar Manero Sorolla, Imágenes petrarquistas en la lírica española del Renacimiento. Repertorio, Barcelona, PPU, 1991). Teniendo en cuenta que los símbolos son fluctuantes y disémicos, dentro de la corriente del irracionalismo europeo, las estabilizaciones del color según Chevalier (op. cit., 744, 788, 1074, passim) no dejan de ser un repertorio sistemático que debe enfrentarse con el proceso textual de la escritura de la poeta argentina para verificar o refutar determinadas hipótesis. Téngase en cuenta, por otra parte, que este universo cromático no puede desgajarse de los contextos en los que se desarrolla este estudio. Así, el verde, equidistante entre el azul celeste y el rojo infernal, como polaridades absolutas e inalcanzables, se revela en ocasiones como un color humano. 
El término "lila" se desdobla en el universo pizarnikiano. Sus dos significaciones (color y flor) son utilizadas por la poeta en diversas ocasiones a lo largo de su producción. Además de ser un color que siempre ha estado ligado a la feminidad, en la poética de Pizarnik el lila se asocia casi siempre a la soledad y a la desolación y, como todos los colores que vamos a analizar, a la muerte. En Árbol de Diana, a la luz lila se le otorga el significado de la nada, ${ }^{73}$ identificándola con ella y creando un paisaje de desolación tras la venida del día: "un golpe del alba en las flores / me abandona ebria de nada y de luz lila". Cuando el poema ya no cubre las necesidades existenciales del sujeto poético, el silencio aparece en primer plano y junto a él, las lilas que acompañan la destrucción de dicho sujeto: "Tú haces el silencio de las lilas que aletean / en mi tragedia del viento en el corazón". Esta flor lila es la que vive en el jardín, aquel cuya naturaleza muerta está ya en ruinas; no es el paraíso deseado, sino que se ha convertido en la soledad imperadora. Es allí donde nacen las lilas, en "el jardín de lilas del otro lado del río" y en "el jardín de ruinas y de lilas", desde donde la muerte la llama, "la muerte lila".

Tal vez el único poema con connotaciones femeninas en lo que al lila se refiere sea "Vértigos o contemplación de algo que termina":

Vértigos o contemplación de algo que termina

Esta lila se deshoja.

Desde sí misma cae

y oculta su antigua sombra.

He de morir de cosas así.

El yo poético podría identificarse con esta flor, una flor que va muriendo poco a poco, que va "deshojándose" y cayendo a esta tierra donde lo único que encontrará es la sombra, su "antigua sombra" que la espera.

Pero en sus últimos poemas el silencio y la desolación se visten de este color. En el poema "Fuga en lila", el silencio "es tentación y promesa"; el color acompañará siempre esta soledad y este deseo de llegar a él. Tanto es así que el poema más largo, y tal vez el más importante de sus últimos textos, se titula "Los poseídos entre lilas", texto poético-dramático en el que

${ }^{73}$ Cfr. Ana María Rodríguez Francia, op. cit., 174: “El empleo del color lila parece oscilar entre la presencia de la luz (alba), la vida que representan 'las flores', y la 'certeza', de lo que remite a muerte: 'nada', 'inmovilidad'. Lo lila implicaría, así, cierta mediación entre ambos extremos". 
las lilas pasan a formar parte del mundo onírico y surreal, de un yo poético resquebrajado por la muerte y el silencio. En él, las imágenes más macabras y ensordecedoras se hacen patentes:

"Restos. Para nosotros quedan los huesos de los animales y de los hombres. Donde una vez un muchacho y una chica hacían el amor, hay cenizas y manchas de sangre y pedacitos de uñas y rizos púbicos y una vela doblegada que usaron con fines oscuros y manchas de esperma sobre el lodo y cabezas de gallo y una casa derruida dibujada en la arena y trozos de papeles perfumados que fueron cartas de amor y la rota bola de vidrio de una vidente y lilas marchitas y cabezas cortadas sobre almohadas como almas impotentes entre los asfódelos y tablas resquebrajadas y zapatos viejos y vestidos en el fango y gatos enfermos y ojos incrustados en una mano que se desliza hacia el silencio y manos con sortijas y espuma negra que salpica a un espejo que nada refleja y una niña que durmiendo asfixia a su paloma preferida y pepitas de oro negro resonantes como gitanos de duelo tocando sus violines a orillas del mar Muerto y un corazón que late para engañar y una rosa que se abre para traicionar y un niño llorando frente a un cuervo que grazna, y la inspiradora se enmascara para ejecutar una melodía que nadie entiende bajo una lluvia que calma mi mal."

Dentro de la enumeración caótica de elementos sexuales, terribles, teratológicos y despedazadores se incluyen esas lilas que la acompañaban en momentos en el que el silencio o el lenguaje podían calmar sus ansias de muerte. Pero aquí ya no es posible esa esperanza, y las lilas se marchitan sin remedio.

El verde es un color medio, situado entre el azul y el rojo. Esto pasará a ser clave en la interpretación de la poesía de Pizarnik, ya que es un color que la acompañará en su descenso a la realidad terrenal; es un color que no pertenece al azul celeste (igual que ella), pero que tampoco ha caído todavía en el rojo infernal. Por lo tanto, será un color que no tendrá unas connotaciones negativas o positivas claras; su significado se irá tambaleando de un extremo a otro según el estado de ánimo del yo poético en ese momento. Esa ambigüedad es la que se destaca en el verso "no llegará lejos el día raro de verdor", en el que el verde no posee ningún vínculo negativo, pero tampoco positivo, simplemente es "raro". Este verde se acerca siempre a la poeta y se identifica con lo que siente en ese momento, sea una prisión en la que no puede ejercer su derecho a la libertad ("con alas de piel verde") o 
un paraíso donde el silencio es creado por ella y donde viven las palabras puras que se alejan de la luz no deseada anterior:

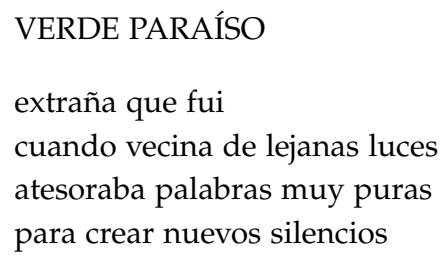

También el verde acompaña en varias ocasiones al mundo natural; es su color esencial y por ello aparece adjetivado por éste: "El agua verde en mi cara" o "la verde alameda".

El color azul será uno de los pocos elementos positivos de Pizarnik. En un principio siempre hará referencia a la bóveda celeste, a ese cielo añorado al que la poeta no es capaz de llegar. En el poema "Cielo" podemos advertir este rasgo: "me digo que es celeste desteñido / témpera / azul puro después de una ducha helada". Irá ligado a todos aquellos seres que pertenecen a ese cielo ("Un pájaro muerto llamado azul"), o incluso será el color del poema cuando éste era una esperanza para ella: "Huella azul en la pared". Sea cual sea el sustantivo al que acompaña, es un color del pasado ("la que murió de su vestido azul está cansada") y que sólo puede poseer el cielo: "cielo raso pintado de azul".

Pero a partir de Los trabajos y las noches, el azul encuentra un refugio en los ojos. Tal vez sea la mirada de su padre, recientemente fallecido; una mirada tranquilizadora y benefactora ${ }^{74}$ que se relaciona con el proceso creativo y guarnecedor del yo poético: 75 "me erguí como la amazona que domina solamente con sus ojos azules al caballo que se encabrita", "En el corazón de

\footnotetext{
${ }^{74}$ André Breton, en su diccionario del surrealismo, hace hincapié en este aspecto al describir el color azul: "Su una mujer desgreñada te sigue no te preocupes. /Es el azul. Nada debes temer del azul" (Buenos Aires, Losada, 2007, 30).

75 “Inmaterial en sí mismo, el azul desmaterializa todo cuanto toma su color. Es camino de lo indefinido, donde lo real se transforma en imaginario. Es también el color del pájaro de la felicidad, el pájaro azul, inaccesible y sin embargo tan cercano. Entrar en el azul equivale a pasar al otro lado del espejo, como Alicia en el País de las Maravillas. El azul celeste es el camino del ensueño, y cuando se ensombrece -ésta es su tendencia natural- pasa a serlo del sueño. El pensamiento consciente deja poco a poco sitio a lo inconsciente, lo mismo que la luz del día pasa a ser insensiblemente luz de la noche" (Chevalier, op. cit., 163-164), pero al que hay que sumar la larga tradición romántica y modernista, dado que, como es sabido, "L'Art
} 
la palabra lo alcanzaron; y yo no puedo narrar el espacio ausente y azul creado por sus ojos".

La mirada de esos ojos aparece como un fantasma alrededor de su poesía, y tal vez sea esa mirada la que llene y colme de dicha al sujeto creador:

"Los sortilegios emanan del nuevo centro de un poema a nadie dirigido. Hablo con la voz que está detrás de la voz y emito los mágicos sonidos de la endechadora. Una mirada azul aureolaba mi poema. Vida, mi vida, ¿qué has hecho de mi vida?"

El rojo rodea todo lo infernal de su poesía: muerte, música, sol, sombra.

Esta sombra aparece ya en el título de un poema "Tratando a la sombra roja", en el que el yo poético se revuelve de dolor en una soledad provocada por el desconocimiento y la nada:

"su soledad maúlla

ceros y ceros

vertiente de valores ingenuos

retina ante desconocido"

Adjetiva al sol ("delante del sol rojo / (no sol amarillo)"), se convierte en verbo para convertir en música su destino ("la música enrojece la ruta") o pasa a ser el color de la vestimenta de las diferentes máscaras poéticas que provocan la desmembración e infelicidad del yo: "Las damas de rojo se extraviaron dentro de sus máscaras aunque regresarán para sollozar entre flores", "Y las damas vestidas de rojo para mi dolor y con mi dolor insumidas en mi soplo".

Pero la verdadera dama de rojo será la muerte. Ella es la que irá vestida de este color en numerosas ocasiones: "la muerte en un vestido rojo, la bella, la funesta, la espectral" , "La muerte de cabellos del color del cuervo, vestida de rojo, blandiendo en sus manos funestas un laúd y huesos de pájaro para golpear mi tumba". Es la muerte aquí un elemento que se correlaciona con la violencia de la pasión, los instintos más animales, que se visten de color de rojo para dar paso a la locura de los últimos textos:

c'est l'azur". Todo este proceso se da desde los primeros textos de Pizarnik, pasando por el pájaro azul, hasta los ojos azules que ensombrecen el camino del ensueño. 
“-Está desnuda pero lleva sombrero, tiene pelos por todas partes y es de color gris de modo que con sus cabellos rojos parece la chimenea de la escenografía teatral de un teatro para locos. Un gnomo desdentado la persigue mascando las lentejuelas..."

El negro es uno de los colores que predominará en todos sus textos. Más que un adjetivo, es un elemento negativo que convierte todo aquello que toca en sombra y muerte. Se asocia a la ausencia de color, la soledad, la desolación, el miedo, el vacío, la nada y, por supuesto, la muerte.

"Es el miedo, / el miedo con sombrero negro / escondiendo ratas en mi sangre". No es el miedo en sí lo que la aterroriza; es su sombrero negro el que convierte ese miedo en algo corrupto que enferma su propia sangre. También son "negras mañanas de sol" o es "viajera de corazón de pájaro negro". Todo aquello que toca el negro, aunque haya sido un elemento fundamental para la ascensión o representación del paraíso de la felicidad, acaba reduciéndose a la soledad espectral y sombría. Incluso las palabras sufrirán este efecto; ya no serán las que la salven de su condena: "Al negro sol del silencio las palabras se doraban".

El viento es negro ("Mi violencia de vientos rojos y de vientos negros") y la oscuridad que ensordece su poesía también es luz negra:

\section{EN LA OSCURIDAD ABIERTA}

Si la más pequeña muerte exige una canción

debo cantar a las que fueron lilas que por

acompañarme en mi luz negra silenciaron sus

fuegos cuando una sombra configurada por mi lamento se refugió

entre sus sombras

La negritud acabará, en los textos de sus últimos años, siendo la consecuencia de una escritura que ya es una esperanza perdida: "A dónde la conduce esta escritura? A lo negro, a lo estéril, a lo fragmentado".

El color amarillo (o dorado), al igual que el azul, estará vinculado a la luz y al sol de los días infantiles, a los que ya no puede regresar el sujeto poético: "al sol amarillo que traspasa las pieles marcando oscuras huellas", "Un sol amarillo dejaba caer indiferente / pedazos luminosos de algo coloreado", "una mosquita junto / al farol amarillosucio". Es el sol que más tarde la penetra y hace mella en su cuerpo, que convierte en algo oscuro y no deseado; aquel sol que pasará a pertenecer al cielo, cielo en el que los pájaros "se doran" y se convierten también en amarillos: 
"Las damas de antaño cantaban entre muros leprosos, escuchaban las trompetas de la muerte, miraban desfilar -ellas, las imaginadas- un cortejo imaginario de muñecas con corazones de espejo y en cada corazón mis ojos de pájara de papel dorado embestida por el viento. La imaginada pajarita cree cantar; en verdad sólo murmura como un sauce inclinado sobre el río."

\section{Espacios poéticos}

La imagen del jardín, ${ }^{76}$ una de las más recurrentes, estará a veces relacionada con la idea de paz y de felicidad, más allá de la muerte, como en el final de "Piedra fundamental", donde dice:

“Cuando el barco alternó su ritmo y vaciló en el agua violenta, me erguí como la amazona que domina solamente con sus ojos azules al caballo que se encabrita (¿o fue con sus ojos azules?). El agua verde en mi cara, he de beber de ti hasta que la noche se abra. Nadie puede salvarme pues soy invisible aun para mí que me llamo con tu voz. ¿En dónde estoy? Estoy en un jardín.

Hay un jardín."

Es el jardín como paraíso perdido pero recuperable, la posibilidad última del Edén. ${ }^{77}$

${ }^{76}$ La imagen del "jardín" como símbolo del paraíso terrenal fluctúa entre el simbolismo abstracto y difuso del mito edénico perdido y nunca recuperado, cuya proyección literaria sería el topos clásico virgiliano del locus amoenus frente al concreto hortus conclusus. El desarrollo del símbolo del jardín: abstracto / concreto de larga tradición en la dialéctica del Neoclasicismo / Romanticismo: frente a la geometría neoclásica del jardín, el desorden del jardín romántico, en cuyo fondo anida lo indescifrable, se proyecta hasta nuestros días. En este sentido cabe recordar que algunos poetas argentinos se han sentido atraídos por este motivo. Entre ellos, Leónidas Lamborghini, El jardin de los poetas, Buenos Aires, Adriana Hidalgo Editora, 1999 (en cuya portada se reproduce un fragmento de El jardín de la delicias de el Bosco) o Arnaldo Calveyra, El hombre de Luxemburgo, Barcelona, Tusquets, 1997.

77 “Es el símbolo por antonomasia del reino perdido. Lugar por excelencia en el cual confluyen todos los componentes del cosmos sagrado, cada vez que se lo nombra el poema alcanza una incomparable coloración nostálgica, pues siempre se habla de él desde la orilla del espacio y el ser sacralizadores. [... Se hablará de él, no como de un lugar donde se estuvo, sino como de la visión de dicho lugar, o como 
A medida que avanza en la composición de una poesía cada vez más desnuda, sus imágenes de la naturaleza adquieren una tonalidad cada vez más sombría: el jardín es triste, las lilas cubren la muerte. Asimismo, vemos que todos esos aspectos son sólo alusiones, sugerencias, para representar su terror, su desolación: ${ }^{78}$

"Pero no hables de los jardines, no hables de la luna, no hables de la rosa, no hables del mar. Habla de lo que sabes. Habla de lo que vibra en tu médula y hace luces y sombras en tu mirada, habla del dolor incesante de tus huesos, habla del vértigo, habla de tu respiración, de tu desolación, de tu traición."

Incluso un símbolo como el jardín, que trae a la memoria tanta connotación de paz, de belleza, se convierte en un espacio prohibido, inalcanzable. Así dirá:

“en la noche del corazón

en el centro de la idea negra

ningún hombre es visible.

Nadie está en algún jardín."

El jardín aparecerá ya petrificado y muerto: "Aunque la voz (su olvido / volcándome náufragas que son yo) / oficia en un jardín petrificado". El jardín está ya desolado y sin vida y se convierte en un espacio para la memoria y el olvido:

“Si vieras a la que sin ti duerme en un jardín en ruinas en la memoria. Allí yo, ebria de mil muertes, hablo de mí conmigo sólo por saber si es verdad que estoy debajo de la hierba. No sé los nombres. ¿A quién le dirás que no sabes? Te deseas otra. La otra que eres se desea otra."

El yo se ha multiplicado en varios seres; una de "ellas" duerme en un jardín que antes fue paz y remanso y que ahora está "en ruinas" y sólo pervive en la memoria. La que está en ese jardín ha sufrido "mil muertes",

de un espacio que se ha recorrido con conciencia de la inminente separación de él" (C. Piña, op. cit. 1981, 28).

78 “La expulsión de ese ámbito edénico es la caída en el espacio de la precariedad y el desamparo. Como este es el espacio desde el que se escribe, la evocación del jardín lo enmarca en calificativos que connotan esa caída mediante su lejanía, su ruina, su petrificación" (Goldberg, op. cit., 30). 
bajo esa hierba que antes la cobijaba. Ahora ya no confía en las palabras que adornaban y daban vida a ese jardín y se desea otra una y otra vez. Es esta fragmentación continuada y eterna la que la lleva a la desolación más absoluta.

También el cuarto se dibuja en los poemas de Pizarnik como centro neurálgico de composición de poesía, además del lugar donde permanece alejada del otro mundo. Es un cuarto que normalmente está repleto de noche y de sombras:

\section{DURACIÓN}

De aquí partió en la negra noche

y su cuerpo hubo de morar en este cuarto

en donde sollozos, pasos peligrosos

de quien no viene, pero hay su presencia

amarrada a este lecho en donde sollozos

porque un rostro llama,

engarzado en lo oscuro,

piedra preciosa.

La soledad es la atmósfera que envuelve al yo poético en "Cuarto solo", y el viento acompañará a esta noche y a este desamparo en "Cuento de invierno"; "La luz del viento entre los pinos [... ] Hasta que logró deslizarse fuera de mi sueño y entrar a mi cuarto, por la ventana, en complicidad con el viento de la medianoche". El viento que hasta entonces vivía en un paisaje de ensoñación ha cruzado la frontera de lo real para instaurarse dentro de su refugio a través de la ventana. Ya no es sólo un lugar de creación, sino también de destrucción.

Tras el viento el silencio ha entrado:

"Alguien habla. Alguien me dice.

Extraordinario silencio el de esta noche.

Alguien proyecta su sombra en la pared de mi cuarto. Alguien me mira con mis ojos que no son los míos."

Se proyecta como una sombra en las paredes que la rodean. Pero no es una sombra cualquiera; tampoco es una de sus múltiples fragmentaciones que ha ido a reunirse con ella. Es la sombra de la muerte, que cada vez está más cerca de ella, incluso en el cuarto que separa su mundo del otro mundo poético de luz que ya no es el deseado. 
La pared ${ }^{79}$ aparece vinculada al cuarto; sin ella ese cuarto no es posible $\mathrm{y}$ son paredes que pueden fisurarse en cualquier momento para dejar que penetre el miedo, la destrucción o el silencio. En "Cuarto solo", la pared es la que posee la verdad; es una pared vieja en la que la violencia de la palabra ha causado desgaste y deterioro, una pared que todavía alberga la esperanza de que aparezca tal vez algo que pueda acabar con la ausencia:

\title{
CUARTO SOLO
}

\begin{abstract}
Si te atreves a sorprender
la verdad de esta vieja pared;

y sus fisuras, desgarraduras,

formando rostros, esfinges,

manos, clepsidras,

seguramente vendrá

una presencia para tu sed,

probablemente partirá

esta ausencia que te bebe.
\end{abstract}

El poema que sigue a éste enlazaría con el segundo verso de "Cuarto solo", puesto que se titula "La verdad de esta vieja pared" ${ }^{80}$ En este poema se nos aclara cuál es esa verdad. Su verdad es el frío, lo verde, el hielo, el temblor por el miedo, "es muro es mero muro es mudo mira muere".

En sus últimos poemas, las paredes son las de un jardín, un jardín roto que está a punto de dejar escapar toda la locura y soledad que guarda en su interior: "Pasos y voces del lado sombrío del jardín. Risas en el interior de las paredes. [...] En cualquier momento la fisura en la pared y el súbito desbandarse de las niñas que fui".

Ligadas al cuarto y a la pared están la ventana y la puerta. La ventana ${ }^{81}$ es la que separa un mundo de otro y es la que deja entrar a uno dentro del

79 “La pared y el correspondiente lexema intensificado, el muro, connotan protección, [... ] pero también el aislamiento y sus peligros" (Goldberg, op. cit., 42).

${ }^{80}$ De esta forma podemos apreciar que la no inclusión de mayúsculas en el primer verso no es casual ya que enlaza directamente con el poema anterior, no sólo por el título sino también por la temática.

81 "Por constituir un agujero expresa la idea de penetración, de posibilidad y de lontananza: por su forma cuadrangular, su sentido se hace terrestre y racional" (Cirlot, op. cit., 462). 
otro para que se produzca la fusión. Dentro está ella o su corazón. ${ }^{82}$ Como vemos en el poema amoroso "La de los ojos abiertos"; "Y todos dicen esto pasó y es / va pasando / va pasando / mi corazón / abre la ventana / vida / aquí estoy".

En "Cuento de invierno", como ya hemos visto, es el viento el que entra, pero no entra por la pared o la puerta; entra por la ventana y pasa de ser una simple ilusión o un sueño a hacerse realidad dentro del cuarto en el que ella vive y crea su poesía, crea su vida. Los "grises pájaros en el amanecer" no encuentran la ventana abierta como el viento y todo aquello que implique decadencia; tienen la "ventana cerrada" y el poema a sus males.

La ventana es la conexión con el mundo exterior al poema. Desde ella se puede ver el fracaso, el vacío, la noche, el cielo ya deteriorado o el agua de la lluvia. Son elementos que aparecen fuera del yo poético y que pertenecen ahora al mundo que está al otro lado:

“-Se abrió la flor de la distancia. Quiero que mires por la ventana y me digas lo que veas, gestos inconclusos, objetos ilusorios, formas fracasadas... Como si te hubieses preparado desde la infancia, acércate a la ventana.

-Un café lleno de sillas vacías, iluminado hasta la exasperación, la noche en forma de ausencia, el cielo como de una materia deteriorada, gotas de agua en una ventana, pasa alguien que no vi nunca, que no veré jamás..."

La puerta ${ }^{83}$ ejerce una función distinta a la de la ventana. Así como la ventana era el espacio visionario del otro mundo, la puerta es la salida de ese mundo en el que vive junto a la angustia y la ausencia. ${ }^{84}$ Pero ella está prisionera y esa puerta no se abre: "Alguien quiso abrir alguna puerta. Duelen sus manos aferradas a su prisión de huesos de mal agüero". También

82 “La ventana es un espejo invertido que muestra al no-yo: una pared que en vez de reflejar los mensajes de la subjetividad encerrada comunica el adentro y el afuera. Límite ambivalente, es a la vez resguardo y contemplación tentadora o angustiante del mundo exterior" (Goldberg, op. cit., 47).

83 “La puerta representa la posibilidad de acceso de un espacio a otro; el resultado puede ser, nuevamente, la comunión o el peligro; inversamente, la puerta que no se deja abrir transmuta el refugio en prisión" (Goldberg, op. cit., 48).

${ }^{84} \mathrm{No}$ es ajena cierta concepción de la poética pizarnikiana a la poética del surrealismo de Magritte, por ejemplo: desde un espacio vacío, en un campo igualmente vacío, la puerta se abre sin muros que la sostengan para, al atravesarla, encontrar, exactamente, al otro lado lo mismo y distinto: el vacío. 
pasa a formar parte en alguna ocasión de su corazón o de su rostro enamorado: "pero cierra las puertas de tu rostro / para que no digan luego / que aquella mujer enamorada fuiste tú", "Puertas del corazón, perro apaleado".

La puerta abierta le hace evocar todo aquello que se encierra en el cielo y en la luz, como, por ejemplo, el pájaro. Pero ahora sólo entran "cenizas de una joven muerta" que se "avientan" y se mezclan con las hojas en las que hay dibujados aquellos elementos que acompañaban a la felicidad (casa, árbol, sol, animal):

“Vendrás a mí con tu voz apenas coloreada por un acento que me hará evocar una puerta abierta, con la sombra de un pájaro de bello nombre, con lo que esa sombra deja en la memoria, con lo que permanece cuando avientan las cenizas de una joven muerta, con los trazos que duran en la hoja después de haber borrado un dibujo que representaba una casa, un árbol, el sol y un animal."

Al final la soledad mortal será la que abra todas las puertas que separan lo vivo de lo muerto, y la muerte se apoderará de todo: "Te hablo de la soledad mortal. [... ] Porque romperá todas las puertas, porque sacará afuera a los muertos para que devoren a los vivos, para que sólo haya muertos y los vivos desaparezcan".

\section{Náufraga eterna}

El ansia de partir hacia una parte distinta de la realidad que la rodea, una parte en la que la felicidad y el amor la esperan, la otra orilla siempre buscada, hace que los símbolos de este viaje hacia la realización de una vida lejana y ajena al dolor y a la angustia no deseada se disparen entre ángeles, pájaros y también barcos. El barco, y su relación con el mar, afronta uno de los viajes más difíciles de la poesía pizarnikiana; será el medio de transporte del que dependerá el destino de su navegante. Es por ello que, al dejar su propia vida en manos de este sino marino, el barco, el mar y sus fulgurantes olas son vistos como destrucción y verdugo, en unas ocasiones, o como esperanza y única salida, en otras. ${ }^{85}$

\footnotetext{
${ }^{85}$ Es uno de los motivos recurrentes de la tradición clásica: elhomo viator por oposición al hombre sedentario.
} 
Ya en su primera obra, dos poemas hacen referencia a esta pretensión de partir hacia una nueva orilla en unos barcos todavía impregnados de inocencia. En "Puerto adelante" deambula por un puerto imaginario acompañada siempre de su soledad, quiere hundirse en su sombra y oscuridad húmeda para irse "Muy junto a ese barco gigante de rayas rojas y blancas y verdes... irse, y no volver". En el poema "Lejanía", incorporado en el apartado "Un signo en tu sombra" de La tierra más ajena, el barco se identifica con el yo enamorado latente en estos poemas, un barco blanco y puro como el sentimiento que la envuelve en esos momentos: "Mi ser henchido de barcos blancos. / Mi ser reventando sentires."

El mar y el amor siguen relacionándose en La última inocencia. En "La enamorada", el barco parte con el amor encantado por las sirenas que lo han alejado de su lado. La poeta debe enmascarar su dolor por la lejanía de éste y por ello ha de conseguir que su rostro no muestre ninguna mueca de angustia y que el pañuelo que saque para despedirse de su barco no denote llanto sino alegría:

"oyes la demente sirena que lo robó
el barco con barbas de espuma
donde murieron las risas
recuerdas el último abrazo
oh nada de angustias
ríe en el pañuelo llora a carcajadas
pero cierra las puertas de tu rostro
para que no digan luego
que aquella mujer enamorada fuiste tú"

El navegante es el único que puede huir del horror ("como el navegante en el horror de la civilización"), y el mar es el único que puede llevarla hacia la salvación a través del lenguaje, de la palabra:

"Dile que los suspiros del mar

Humedecen las únicas palabras

Por las que vale vivir"

Partir. Partir hacia una playa distinta y no volver, hacia un nuevo paraje en el que la luz del sol y su sangre no sean capaces de dolerle ni angustiarle como ahora lo hacen. Partir para dejar atrás todo aquello que oprime su existencia. Partir impetuosamente: 


\section{La última inocencia}

Partir

en cuerpo y alma

partir

Partir

deshacerse de las miradas

piedras opresoras

que duermen en la garganta

He de partir

no más inercia bajo el sol

no más sangre anonadada

no más formar fila para morir

He de partir

Pero arremete ¡viajera!

Deseo de viajar de su alma y su cuerpo. No sólo del alma, como el pájaro o el ángel deseaban; ahora también el cuerpo la acompañará en esta travesía, alejándose sin remedio de todo aquello que la oprime mediante un paralelismo continuado: las miradas y las palabras que subyugan su existencia, la propia realidad en la que sólo cabe esperar la muerte. Debe partir, con fuerza y frenesí, para lograr su fin. La necesidad de viajar se prolonga en su tercera obra, Las aventuras perdidas: "Pero esta inocente necesidad de viajar / entre plegarias y aullidos". El mar y sus barcos son su única esperanza de salida en el infierno de la duplicidad; el mar es el único que puede acabar con las diferentes imágenes líricas que se reflejan en el espejo de la multiplicidad:

“¿Cómo no me suicido frente a un espejo

y desaparezco para reaparecer en el mar

donde un gran barco me esperaría

con las luces encendidas?" 
Es el mar, ${ }^{86}$ junto al pájaro que también navega por la inmensidad del cielo azul, el que otorgará el amor y la ventura a la poeta:

“Hemos creado el sermón

del pájaro y el mar,

el sermón del agua,

el sermón del amor."

Pero esto es sólo un sueño. La realidad en la que se desenvuelve su existencia es muy diferente; en ella los barcos navegan sin rumbo y sin destino hacia un mar que se convertirá en su propio verdugo:

"Yo lloro debajo de mi nombre.

Yo agito pañuelos en la noche

y barcos sedientos de realidad

bailan conmigo."

"Llamé, llamé como la náufraga dichosa

a las olas verdugas

que conocen el verdadero nombre

de la muerte."

El mar está fuera de su alcance; estará del lado de la luz y del sol, pero ajeno a ella: "El mar ajeno y doblemente mudo / en el verano que apiada por sus luces". La poesía, como creación, tampoco puede crear en su mundo lírico todos esos objetos que ella misma no es capaz de alcanzar; ni jardines, ni mares, ni lunas: "En un muro blanco dibujas las alegorías del reposo [...]. Pero no hables de los jardines, no hables de la luna, no hables de la rosa, no hables del mar". Este lenguaje, por más que se esfuerce, no puede llevarla al objeto nombrado. Por más que la palabra desentierre un mundo, no le proporcionará ese mismo mundo en el que se ha reflejado para nombrarlo:

"Esperando que un mundo sea desenterrado por el lenguaje, alguien canta el lugar en que se forma el silencio. Luego comprobará que no porque se muestre furioso existe el mar, ni tampoco el mundo."

86 “Su sentido simbólico corresponde al del 'océano inferior', al de las aguas en movimiento, agente transitivo y mediador entre lo no formal (aire, gases) y lo formal (tierra, sólido) y, analógicamente, entre la vida y la muerte. El mar, los océanos, se consideran así como la fuente de la vida y el final de la misma" (Cirlot, op. cit., 305). 
Lo único que hay tras el lenguaje es el silencio, y por más que la poeta se esfuerce en representar el mundo con sus versos, ese mundo no aparece; lo único que queda después es silencio. Es, por lo tanto, un mar muerto en el que "los gitanos de duelo tocan sus violines a orillas del mar Muerto y un corazón late para engañar y una rosa que se abre para traicionar". Si el mar no existe a través de la poesía, es un mar muerto en el que todo elemento se convierte en algo funesto y terrible.

También el río, ${ }^{87}$ en la obra poética de Pizarnik, es un río relacionado con la muerte. Es el Leteo en el que las almas y los cuerpos muertos flotan y navegan. No es de extrañar, pues, que en él encontremos cadáveres flotantes ("beber de mí luego de haber matado al rey que flota en el río y mueve los ojos y sonríe pero está muerto, y cuando alguien está muerto, muerto está por más que sonría" o "el padre, que tuvo que ser Tiresias, flota en el río") o voces que la llaman hacia la muerte:

"Toda la noche escucho el llamamiento de la muerte, toda la noche escucho el canto de la muerte junto al río, toda la noche escucho la voz de la muerte que me llama.

$\mathrm{Y}$ tantos sueños unidos, tantas posesiones, tantas inmersiones en mis posesiones de pequeña difunta en un jardín de ruinas y de lilas. Junto al río la muerte me llama. Desoladamente desgarrada en el corazón escucho el canto de la más pura alegría."

En este largo poema "El sueño de la muerte o el lugar de los cuerpos poéticos", el río pasa a ser el elemento principal en el que la muerte canta su melodía victoriosa sobre el yo poético, lo llama sin descanso y oculta todo aquello que antes fue y que ahora se esconde en su cauce mortal. El río también es destrucción en este poema, y el sujeto lírico se pregunta por qué se encontraba en ese lugar antes de que el río invadiera con su torrente violento todo lo que vivía allí: “¿Qué hubo en el fondo del río? ¿Qué paisajes se hacían y deshacían detrás del paisaje en cuyo centro había un cuadro donde estaba pintada una bella dama que tañe un laúd y canta

\footnotetext{
${ }^{87}$ Desde la tradición bíblica: “omnia flumina intran in mare et mare non redundant" (Eclesiastés cap. 1 v. 7) y en conexión con el motivo seminal de Heráclito, el río configura un símbolo inmutable en todo el imaginario poético hasta ese Tiresias "que flota en el río" procedente de Apollinaire y que actúa como un símbolo andrógino (Apollinaire, El encantador putrefacto. Las tetas de Tiresias, Buenos Aires, Losada, 2009).
} 
junto al río?". Quiere ver el fondo del río para ver si detrás de él hay algo que se "irrumpe y florece del lado de aquí". Pero esa dama es la muerte "desde donde el fondo del río está la muerte cantando". Es la "muerte de los cabellos del color del cuervo, vestida de rojo, blandiendo en sus manos funestas un laúd y huesos de pájaro para golpear en mi tumba". Eso es lo único que se esconde detrás del río. De esta forma, el poema o el sueño se vuelve a cerrar en los últimos párrafos como empezó: "La muerte está cantando junto al río".

La orilla, sea del mar o sea del río, es aquí un símbolo de la duplicidad de los mundos y del límite entre ellos. El cuerpo poético se encuentra a un lado del río, en una de sus orillas; y el resto del mundo, al otro. Ella se desdobla entre los dos y vive a caballo entre la infancia perdida y la pesadez de la ausencia en la que ahora navega: "Yo no sé de la infancia / más que un miedo luminoso / y una mano que me arrastra / a mi otra orilla".

El texto "Desde esta orilla" ejemplifica esta duplicidad entre el universo solar y la orilla de la muerte donde la nostalgia y la melancolía azotan al yo:

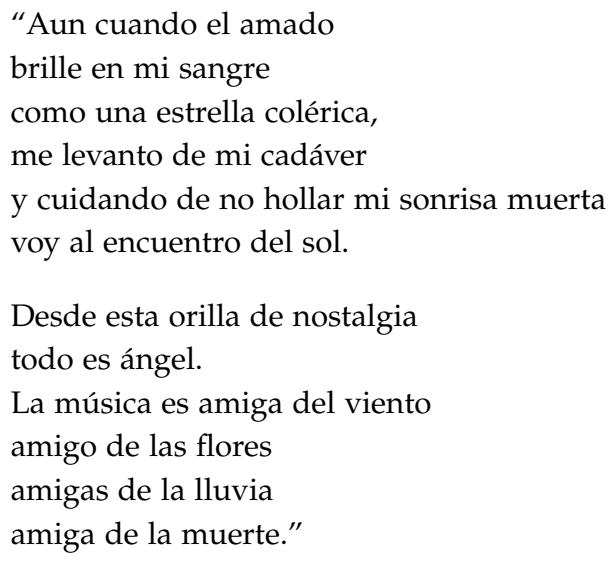

En un lado están el amado y el sol, y en el lado de la muerte conviven la muerta y la nostalgia, acompañadas por los signos de la destrucción: la música, el viento, la lluvia y la muerte.

Siempre es la "otra", el indefinido de lejanía respecto al sujeto, la que aguarda con una vida mejor, la que todavía conserva el amor, pero a la que no se puede llegar. El sujeto poético la interpela constantemente para que la deje ir a su lado y poder disfrutar del paraíso amoroso: "en la otra orilla 
de la noche / el amor es posible / -llévame- / llévame entre las dulces sustancias / que mueren cada día en tu memoria".

\section{Monstruos y seres mitológicos}

Seres mitológicos y fantásticos pueblan algunos de los poemas de A. Pizarnik. El término genérico "monstruos" aparece en el poema "Sueño", en el que el paso del tiempo y la pérdida de la infancia hacen que los barcos en que viajan todas sus máscaras no lleguen a la "playa" deseada a causa de esos "monstruos" que la han destruido. Esa playa pertenece a "la isla del recuerdo", aquella que alberga el sol y la luz de los recuerdos infantiles, aquella a la que no podrá volver de nuevo, puesto que el tiempo se ha convertido en "prisión" y los "monstruos" la han destruido para siempre, reservándola sólo para el recuerdo y tal vez el olvido. La isla "ha estallado" y mediante la interposición del adverbio "Mañana" como única unidad versal, el futuro se nos describe como una incógnita, como un "vidrio de misterio".

En "El despertar" estos monstruos viven ahora "detrás del aire":

Señor

El aire me castiga el ser

Detrás del aire hay monstruos

que beben de mi sangre

Estos monstruos se han creado bajo el aire que da la vida, y cuando ésta falta reaparecen y acaban con la suya, vampirizan su cuerpo convirtiéndolo en algo inerte que ni vive ni muere, pasea entre dos realidades.

También las brujas tienen un papel en la poesía pizarnikiana. No simbolizan tanto el poder de la noche y de los conjuros y embrujos como el de las artes adivinatorias, al igual que Tiresias. Hacen su primera aparición en un poema de título significativo, "Reminiscencias quirománticas", 88 en el que las brujas son las adivinas del futuro a través de las manos: "dos manos de flores pendiente resumen la / burda escultura de exóticas formas que / brillan vendiendo a las brujas el / augusto signo de vida por muerte". La relación se establece con las manos, puesto que son las únicas capaces de

\footnotetext{
${ }^{88}$ La quiromancia como reverso del análisis clínico configura buena parte del imaginario argentino contemporáneo. Si en el primero lo que prevalece es el azar o el destino, en el segundo se trata de someter a la razón lo irracional.
} 
interpretar el futuro que se describe en sus líneas, aunque ese destino estará lleno de música y muerte:

“Pero un pájaro muerto

vuela hacia la desesperanza

en medio de la música

cuando brujas y flores

cortan la mano de la bruma.

Un pájaro muerto llamado azul."

La noche de las brujas es la portadora de la ausencia y de la soledad; es el oasis en el que son capaces de hacer conjuros de abandono y alejamiento, capaces de secuestrar a la "hija del viento"; "Por qué estas noches como un oasis para brujas / Por qué esta conjuración de ausencias / Este secuestro de la hija del viento". A través de las preguntas retóricas causales, el yo poético sufre la noche desoladora en su "corazón absurdo", que llama al amor a través de la anáfora y el paralelismo de sus términos, incluyendo una paranomasia entre los términos "amo" y "llamo", pero ese amor nunca responderá a su reclamo: "Me rodea en la noche una logia exterminadora / Te llamo y no vienes / Te amo y no vienes".

Este mundo de la noche conforma un clima de seres no tangibles en el que la sombra, lo fantasmal y lo espectral ${ }^{89}$ son los dueños. Pueden aparecer como sustantivos o adjetivos, pero siempre denotarán un mundo en el que lo tangible no tiene cabida. Si el yo poético está viviendo en la muerte, su cuerpo no es el que vive, sino sólo su espectro, que vaga por la noche. Todo es fantasmal y no puede retenerse. Lo espectral y fantasmagórico acompaña a todo su mundo, y lo sumerge en un clima onírico y encantado: "la culpas fantasmas", "lúbricos rostros adolescentes, / entre ellos soy otro fantasma", "Esta espectral textura de la oscuridad". Incluso las piedras son fantasmas, piedras que se convierten en palabras por repetición paralelística del segundo y último verso:

89“La sombría o luminosa procesión de espectros que desfilan en las visiones de Alejandra Pizarnik responde al deseo que ha soñado antes que al que le ha sido satisfecho" (Koremblit, op. cit., 65). 


\begin{abstract}
"Perdida en el silencio
de las piedras fantasmas.

Quién es el heredero del viento, quién me llena la boca de días, quién hace que yo viva?

Quién prueba una verdad en mi dolor sin fondo?

Quién me ha exilado con los que cantan?

Quién me perdió en el silencio

de las palabras fantasmas?"
\end{abstract}

Estas piedras y estas palabras habitan en el silencio, un silencio que, al igual que lo fantasmagórico, no se puede tocar, pero sí sentir.

En cuanto a los seres mitológicos, dos son los que aparecen en la obra poética de A. Pizarnik: la sirena y el Cancerbero. La sirena siempre va ligada al mar y a los barcos. Es su canto el que hace que los barcos que navegan hacia uno de los mundos pizarnikianos donde se halla el amor naufrague y no llegue a su destino, causando el dolor del amor no correspondido de "La enamorada"; "oyes la demente sirena que lo robó / el barco con barbas de espuma / donde murieron las risas / recuerdas el último abrazo".

El Cancerbero, ${ }^{90}$ animal mitológico de tres cabezas que ejercía la función de portero de las cavernas del Hades griego, para que los vivos no pudieran entrar ni los muertos salir, actúa en el poema "Noche" como única puerta del alma poética, que no deja traspasar todo lo que la realidad externa a ella puede proporcionarle. Es por ello que le grita y le pide que la deje salir:

“¡Quiero salir! Cancerbero del alma:

¡Deja, déjame traspasar tu sonrisa!

¡Pudiera ser tan feliz esta noche!

Aún quedan ensueños rezagados.

¡Y tantos libros! ¡Y tantas luces!

¡Y mis pocos años! ¿Por qué no?"

${ }^{90}$ César Vallejo ya utiliza este animal mitológico en el poema L de Trilce: “El cancerbero cuatro veces / al día maneja su candado, abriéndonos / cerrándonos los esternones, en guiños / que entendemos perfectamente" (César Vallejo, Trilce, Madrid, Cátedra, 1991, 237). 


\section{El cuerpo ${ }^{91}$ y la sangre}

La sangre es lo que da vida al cuerpo y al alma. El yo poético se identifica en él y sufre a través de ella. Toda la poética pizarnikiana está construida sobre una gran metonimia que abarca la mayoría de sus textos, en los que la sangre pasa a ser el propio yo, el que sufre la destrucción y el silencio constantemente: "mi vida / mi sola y aterida sangre / percute en el mundo", "el miedo / pasea por mi sangre / arranca mis mejores frutos / devasta mi lastimosa muralla", "¡Faltan palabras, / falta candor, falta poesía / cuando la sangre llora y llora!".

Si la sangre sufre la devastación del viento, de la música y de otros elementos destructivos, esto repercute en todo el yo, no sólo en la parte más corporal, que será representada por los huesos, sino también en lo más profundo del alma poética: "Han venido. / Invaden la sangre. / Huelen a plumas, / a carencia, / a llanto", "Sólo la música de la sangre /asegura residencia / en un lugar abierto".

En "Nada" es en la puerta abierta de su sangre, su herida, donde el viento viene a morir; y la noche, personificada en una mendiga, tiene sed de sangre, la necesita para poder vivir a través de ella:

Nada

El viento muere en mi herida.

La noche mendiga mi sangre.

Es la noche la que necesita de su sangre. Este efecto vampirizador en el que la sed y la sangre confluyen en un deseo ardoroso se consolida en uno de sus poemas más telúricos y sangrientos, "Sortilegios"; "y a mí que nadie me enseñó a llorar y nadie me enseñará ni siquiera las grandes damas adheridas a la entretela de mi respiración con babas rojizas y velos flotantes

${ }^{91}$ Acerca del estudio del cuerpo en la poesía de Pizarnik, David William Foster afirma: "Thus, to study the representation of the body in pizarnik and to pursue the complex images of suffering, displacement, and dismemberment -all with the overtones of death and, ultimately a growing concentration of references to suicidenecessarily involves more than either the compilation of a corporal lexicon for her texts or the examination of localized processes inscribed with a generalized rhetoric of metonymic animation, anthropomorphization, personification, and hypostasis" ("The body in the Poetry of Pizarnik", Hispanic Review, 62, 3, 194, 344). 
de sangre, mi sangre, la mía sola, la que yo me procuré y ahora vienen a beber de mí luego de haber matado al rey que flota en el río".

El amor y el sexo están relacionados íntimamente con la sangre en sus poemas. En la segunda parte del poema "Los poseídos entre lilas" se nos describe una estampa de sexo carnal y violento en el que la sangre se entremezcla con el amor, las cenizas de la muerte, las uñas, rizos púbicos y manchas de esperma. La sangre pasa a formar parte de los "restos" que quedan de los hombres y de los animales, aquellos que ya no viven y que la noche y el viento han devastado hasta dejarlos sólo con sus instintos más carnales: "Restos. Para nosotros quedan los huesos de los animales y de los hombres. Donde una vez un muchacho y una chica hacían el amor, hay cenizas y manchas de sangre y pedacitos de uñas y rizos púbicos y una vela doblegada que usaron con fines oscuros y manchas de esperma sobre el lodo y cabezas de gallo".

Los huesos serán la otra cara de la moneda del yo poético. Así como la sangre representa la vida, los huesos irán asociados, prácticamente en todos sus poemas, a la muerte. Forman parte de la metonimia del cuerpo y el alma del sujeto poético, y sus connotaciones son siempre de errancia, soledad y desamparo: "sin piedad por mi nombre / ni por mis huesos que lloran vagando", "he de volver a mis huesos en duelo", "Al filo de la madrugada los huesos te dolían". Siempre relacionados con la noche y la muerte, se perfilan como una nota sinestésica de color o de tacto en algunos versos: "la noche bebió vino / y bailó desnuda entre los huesos de la niebla", versos en los que los huesos representarían el color de la niebla fundiéndose en ella e, identificando el primer término de la metáfora con el segundo, convirtiendo la niebla en la poseedora de los huesos y no en metáfora de ellos; o "Y de tanto animal muerto en el cementerio de huesos filosos de mi memoria", en el que los huesos sufren una transformación polisémica: por un lado, son los huesos de los hombres muertos del cementerio; por otro, son aquellos que rompen su memoria con sus cantos rotos y filosos.

Incluso llegan a identificarse con la música, con un silencio que se ha multiplicado en varios, de modo que se diluye la posible paz que pudiera proporcionarle:

“Esta espectral textura de la oscuridad, esta melodía en los huesos, este soplo de silencios diversos, este ir abajo por abajo, esta galería oscura, oscura, este hundirse sin hundirse." 
Las manos tienen tres posibles significados en la poesía pizarnikiana: elemento de adivinación en el que se puede leer el futuro; conductoras del yo lírico hacia la muerte, el amor, la destrucción o la otra orilla; o manos estranguladoras y asesinas.

Como elemento de adivinación, las manos tienen la capacidad de deletrear el futuro a través de sus líneas, que son interpretadas por brujas: "dos manos de flores pendientes resumen la / burda escultura de exóticas formas que / brillan vendiendo a las brujas el / augusto signo de vida por muerte". En este poema, "Reminiscencias quirománticas", este arte de la adivinación es rechazado, ya que ella sabe cuál es su futuro: la muerte; no necesita que nadie la engañe diciéndole lo que puede ocurrirle durante la vida si el destino final de su "sangre" es la muerte. Esta muerte es lo que había en la palma de la mano, que al cerrarse acaba con cualquier posibilidad de vida: "yo habito en la palma de su mano cierra sus dedos un polvo dorado un poco de sangre adiós oh adiós".

Entronca así, a través de las manos, la predicción con el asesinato. La inocencia es la que ha muerto: "Se quiso detener el avance de las manos enguantadas / que estrangulaban a la inocencia". Quienes han cometido tal crimen son los "mensajeros en la noche", que han acabado con tan querido tesoro, el único que podía unirla al mundo deseado. A partir de aquí "vivimos con una mano en la garganta", unas manos exterminadoras: "Las muñecas desventradas por mis antiguas manos de muñeca".

Pero las manos son también la parte corporal de la guía y la conducción de otros seres u objetos. "Échame una mano" o "tiéndeme tu mano", se dice coloquialmente. Esta mano puede pertenecer a la noche ("noche que te vas/ dame la mano"), una mano espectral que la conduce de una realidad a otra ("y una mano que me arrastra / a mi otra orilla"), que arrastra a uno de sus sujetos poéticos hacia el espejo: "Una mano desata tinieblas, una mano arrastra la cabellera de una ahogada que no cesa de pasar por el espejo".

Estas manos son morada de la ausencia, las que buscan el "vaso" que calmaría su "sed" sin llegar a conseguirlo en ningún momento:

MORADAS

\section{a Théodore Fraenkel}

En la mano crispada de un muerto, en la memoria de un loco, en la tristeza de un niño, 
en la mano que busca el vaso,

en el vaso inalcanzable,

en la sed de siempre.

Los ojos ejercen la misma función que la ventana en el cuarto. Son la única salida y entrada por la que los dos mundos se pueden comunicar. El mundo de la luz, del sol, del alba, de la inocencia vive fuera de ella, y sólo es recordado cuando los ojos están abiertos:

\section{La de los ojos abiertos}

la vida juega en la plaza

con el ser que nunca fui

y aquí estoy

baila pensamiento

en la cuerda de mi sonrisa

y todos dicen esto pasó y es

va pasando

va pasando

mi corazón

abre la ventana

vida

aquí estoy

mi vida

mi sola y aterida sangre

percute en el mundo

pero quiero saberme viva

pero no quiero hablar

de la muerte

ni de sus extrañas manos

Los ojos y la ventana se identifican para crear un mundo diferente del mundo donde vive "sola y aterida", donde la muerte hace su aparición; pero con la apertura de esos ojos hacia el otro lado intenta desenfocar la mirada mortal que la persigue. Es a través de los ojos abiertos que puede ver "una 
rosa hasta pulverizarse los ojos" o "la extensión del alba." En "Ojos primitivos"92 estos ojos que antes se abrían y encontraban "cuentos y poemas", palabras que la salvaban de la soledad austera, pero que ahora ya son primitivos, ya no pueden seguir mostrándole estos objetos pacificadores: "En donde el miedo no cuenta cuentos y poemas, no forma figuras de terror y de gloria".

Los ojos cerrados encierran todo lo negativo de los poemas de Pizarnik: el desdoblamiento, el viento, la muerte, la oscuridad: "Como el viento sin alas encerrado en mis ojos / es la llamada de la muerte". Los ojos cerrados hacen que se desdoble y que la creación poética se desarrolle:

\section{1}

Es un cerrar los ojos y jurar no abrirlos. En tanto afuera se alimenten de relojes y de flores nacidas de la astucia. Pero con los ojos cerrados y un sufrimiento en verdad demasiado grande pulsamos los espejos hasta que las palabras olvidadas suenan mágicamente.

En el exterior, el tiempo y las flores crecen sin poder saber lo que se está gestando en los ojos, "las palabras" que "suenan mágicamente". Este desdoblamiento se acentúa en el poema "19" de Árbol de Diana: "cuando vea los ojos / que tengo en los míos tatuados". En "L'obscurité des eaux", la creación lingüística llega a crear unos nuevos ojos que se sumergen en las aguas del silencio, caminan entre visiones nocturnas hasta chocar contra el viento: "Dibujo en mis ojos la forma de mis ojos, nado en mis aguas, me digo mis silencios". A pesar de dibujarse otros ojos, los anteriores siguen cerrados y lo único que pueden mirar es a ella misma caminando bajo la lluvia hacia el silencio, la ausencia y la nada.

\footnotetext{
${ }^{92}$ María Negroni dice lo siguiente respecto a este poema: “En su poema ‘Ojos primitivos', [... ] el círculo se cierra. El lenguaje, desnudado, se revela como carnalidad aniquilada. La poesía desemboca en la imposibilidad de nombrar o, quizá sería más justo decir, de nombrar sin destruir o congelar" (Negroni, op. cit., 30).
} 


\section{Reflejos del espejo}

El espejo es el símbolo del doble por excelencia. Es la puerta en la que los mundos poéticos pizarnikianos convergen y se reflejan, aquel elemento a través del cual se muestra aquello que no es la realidad, pero que forma parte esencial del yo. Así, en los poemas de Pizarnik, el espejo será la ventana que mostrará los múltiples universos que conforman el todo poético. Pueden reflejarse tanto el espacio deseado como el espacio de la muerte o el silencio, puesto que el espejo es la causa de dos imágenes, una real y otra ficticia, una que la disuelve en la desolación y otra que provoca su deseo de volar hacia ella.

En el lado del espejo del deseo se mira el poema "14" de Árbol de Diana: “¿Cómo no me suicido frente a un espejo / y desaparezco para reaparecer en el mar / donde un gran barco me esperaría / con las luces encendidas?". En el otro lado del espejo está la realidad, lo que el sujeto poético es: "hoy te miraste en el espejo / y te fue triste estabas sola", "un espejo para la pequeña muerta / un espejo de cenizas", "hay un espejo para nuestra triste transparencia", "Miedo de ser dos / camino del espejo". Pero gracias a la duplicidad provocada por el reflejo de este objeto la poesía ha podido nacer en el yo poético: "Ella es su espejo incendiado", "pulsamos los espejos hasta que las palabras / olvidadas suenan mágicamente". Acaba aceptando esta dualidad y reconociendo que es el único amor que la ha acompañado durante su descenso y caída: "He tenido muchos amores -dije- pero el más hermoso fue mi amor por los espejos".

"Caminos del espejo" sería el poema que reflejaría esta dualidad constante de los sujetos poéticos de la poesía de Pizarnik (subrayamos en cursiva estas dualidades de los fragmentos más significativos del poema):

\section{Caminos del espejo}

II

Pero a $t i$ quiero mirar te hasta que $t u$ rostro se aleje de mi miedo como un pájaro del borde filoso de la noche.

III

Como una niña de tiza rosada en un muro muy viejo súbitamente borrada por la lluvia. 
$\mathrm{V}$

Todos los gestos de mi cuerpo y de mi voz para hacer de mí la ofrenda, el ramo que abandona el viento en el umbral.

VI

Cubre la memoria de tu cara con la máscara de la que serás y asusta a la niña que fuiste.

VII

La noche de los dos se dispersó con la niebla. Es la estación de los alimentos fríos.

VIII

Y la sed, mi memoria es de la sed, yo abajo, en el fondo, en el pozo, yo bebía, recuerdo.

XII

Pero el silencio es cierto. Por eso escribo. Estoy sola y escribo. No, no estoy sola. Hay alguien aquí que tiembla.

XIII

Aun si digo sol y luna y estrella me refiero a cosas que me suceden. ¿Y qué deseaba yo? Deseaba un silencio perfecto. Por eso hablo.

XV

Delicia de perderse en la imagen presentida. Yo me levanté de mi cadáver, yo fui en busca de quien soy. Peregrina de mí, he ido hacia la que duerme en un país al viento.

XVI

Mi caída sin fin a mi caída sin fin en donde nadie me aguardó pues al mirar quién me aguardaba no vi otra cosa que a mí misma.

XIX

Deslumbramiento del día, pájaros amarillos en la mañana. Una mano desata tinieblas, una mano arrastra la cabellera de una ahogada que no cesa de pasar por el espejo. Volver a la memoria del cuerpo, he de volver a mis huesos en duelo, he de comprender lo que dice mi voz.

La consecuencia de este reflejo en el espejo es la ruptura del yo poético en varias voces, rostros y máscaras. Éstos se multiplican a lo largo de los poemas y conforman un universo de dobles que vagan por los poemas repartidos en la noche, la muerte y la soledad: "No querer voces robando / semillitas arqueadas aéreas", "tres voces fonean tres besos" (tal vez sean la del yo, el tu y el otro, las tres alejandras), "Son mis voces cantando / para 
que no canten ellos". En "Piedra fundamental" y "Del otro lado", la multiplicidad de estas voces conformarán el verdadero yo poético: "No puedo hablar con mi voz sino con mis voces".

María Negroni asevera en su libro El testigo lúcido:

Está claro, la voz en Pizarnik nunca es unívoca: no controla ni estabiliza al sujeto de la enunciación, no lo completa ni ratifica. Siempre, a su lado, hay la conciencia de la pluralidad de voces que lo habitan, del divorcio entre sujeto, mundo y palabra, de la otredad (indiscernible del tú) que es el yo.

M. Negroni, op. cit., 77

Los rostros, paredes del cuarto que la separan del exterior edénico, también se multiplican y pasan a ser miles: "un viento débil / lleno de rostros doblados", "Y he bebido licores furiosos / para transmutar los rostros / en un ángel", "y vienen los perdonadores / de lo que cometieron mil rostros míos".

Por encima de ellos aparecen las máscaras. Las voces múltiples se esconden tras los rostros que, a su vez, también se multiplican y crean un desorden y un caos de sujetos poéticos. Al tapar el rostro con máscaras, la infinitud de desmembraciones y duplicaciones se eterniza: "Máscaras verdes bajo la lluvia”, "Nombres que vienen, sombras con máscaras". 



\section{Conclusión}

A lo largo de este estudio nos hemos propuesto analizar de un modo exhaustivo los fundamentos poéticos y simbólicos de la poética de Alejandra Pizarnik. Para ello se ha configurado una selección de aspectos fundamentales de cada una de las obras de la escritora argentina. El yo poético mantiene con el lenguaje, el silencio y el poema un vínculo que es indestructible a lo largo de toda su producción. La tensión y el combate sostienen la tensión entre el sujeto poético y la palabra, y ésta es la que permite la oscilación entre la desolación y la batalla por la vida.

El camino iniciado por Pizarnik desde la adolescencia alcanza mayor plenitud a partir del significativo viaje a París. En sus primeros textos se impregna de la temprana influencia neorromántica y más tarde surrealista, aunque son numerosos los críticos que no la encasillan en este movimiento, debido a la falta de automatismo en sus poemas (aunque dados / dedos). Alejandra Pizarnik construye el poema a través de la palabra. No sólo el poema, sino también su propia realidad. Tras la caída en la pesadez terrenal desde un cielo o desde un jardín supuestamente edénico, el sujeto lírico inicia su particular descenso a los infiernos mediante la poesía. Es algo que se aprecia desde sus primeras obras.

En La tierra más ajena, obra repudiada por ella misma, ya se intuye el inicio de un camino hacia la búsqueda de la muerte, símbolo que irá evolucionando hasta disociarse de la poesía y convertirse en ella misma. En ésta, los rasgos románticos y surrealistas son evidentes, pero también son preludio del silencio musical posterior. El amor hace su primera aparición aquí, un amor que se irá desintegrando en la oscuridad nocturna debido a su disolución en el silencio. 
La última inocencia y Las aventuras perdidas representan un giro respecto a su obra anterior, puesto que se muestra ya como una auténtica dominadora del lenguaje. En estas dos obras se presentan los temas fundamentales que la acompañarán hasta el final, como el encanto por la muerte, la meditación sobre la poesía y la creación, la noche como insignia o la duplicidad del yo poético y el miedo que éste conlleva. La concepción poética sufre una mutación y se dirige hacia la concentración y el hermetismo. En estos libros ya no cabe esperar nada de la vida y, por lo tanto, la salvación será sólo posible a través de la palabra -espejismo al fin- $y$, en ocasiones en la muerte, a la que siempre espera: "Pero arremete ¡viajera!". En Las aventuras perdidas, su vínculo con los románticos alemanes se acentúa; sobre todo, inciden en su poesía en lo que se refiere al gusto por lo onírico y el subconsciente. La noche, la soledad, la niñez aterrada, son los constituyentes de unos textos intimistas, líricos y dialógicos en los que finalmente el yo es tú, el tú es yo y je est otre. También el amor es desesperanzado, puesto que el amante siempre es amante perdido o ausente.

A partir de Árbol de Diana, sus libros se pueden analizar como un solo poema largo, puesto que mantienen una gran coherencia poética. Árbol de Diana supone una inclinación hacia el poema conciso, que configura un nuevo tipo de poesía de una expresividad incontrolable. El silencio, la muerte, la noche (como he indicado anteriormente), las reiteraciones continuadas, la nominalidad, aportan tal expresividad que el poema se acorta de forma inherente a su creación. Pero este libro no rompe con la trayectoria iniciada con anterioridad; en esencia, las interrogaciones que desde un principio acuciaban al sujeto poético no han cambiado, sino que van adquiriendo cualidades visionarias y sin énfasis, transformándose de esta forma en universales. Todo esto sin dejar de lado un imaginario inocente e infantil que facilita la aprehensión intuitiva de sus razonamientos. Es en este libro donde se desarrollarán las ambigüedades de los extremos. Una de sus voces surgirá desde la otra orilla del río, donde habita la infancia, infancia que ya no es la que se creía que era.

En Los trabajos y las noches, la degradación de la vida desde el paraíso original es la que llevará sus poemas al oscurantismo terrenal. La trasposición del día en noche se hace patente en ellos, y ésta pasa a ser el nuevo "paraíso" de su poética, discriminando la luz de los libros anteriores. Pero es en Extracción de la piedra de locura y El infierno musical donde el tono se vuelve desesperanzado y trágico. El poema pasa a ser un metatexto en el que se repiten numerosas preguntas a la propia poesía, aunque ésta no re- 
sponda a ellas. Aquí el lenguaje ya no implica la salvación de la poeta; todo conduce a la oscuridad, la sombra y la noche. Su realización en la multiplicidad ("No puedo hablar con mi voz sino con mis voces"; "distinta de mí misma entre vuestras plumas ando", afirmaría Sor Juana Inés de la Cruz) se repite sin descanso y provoca la angustia de la poeta ante el vacío o la ausencia. La palabra ha adquirido autonomía y libertad absoluta, y la escritora ya no la puede controlar. Pizarnik buscará consuelo en el silencio, aunque el yo poético quedará vacío, desierto, deshabitado -la tierra más ajena: The waste land, Eliot- y solo en las llamas vacías de su propio infierno.

Esta doble cara de la evolución poética pizarnikiana se ejemplifica a través de los símbolos, convertidos en su mayoría en personajes recurrentes en toda su obra. Por un lado, los elementos que configuran su sistema poético prevalecen a lo largo de su producción y crean una trama que refuerza la idea de considerar sus textos como uno solo; por otro lado, algunos de esos elementos que confieren unidad al complejo sistema de poemas evolucionan al mismo tiempo que el silencio y la oscuridad se adueñan del yo lírico, mientras que otros permanecen inmutables ante tal evolución o desaparecen a medida que el oscurantismo, la muerte y el silencio disuelven la posible salvación en el lenguaje y por el lenguaje.

La muerte y el silencio están ligados al lenguaje de forma indisoluble. Son los ejes que articulan la poesía más recordada de Alejandra Pizarnik. A partir de aquí se entretejen los símbolos mezclando la desolación, la destrucción, el vacío y la ausencia con el recuerdo (u olvido) del jardín paradisíaco y los días de sol. Varios son los campos simbólicos que se reúnen en los versos pizarnikianos: el universo celeste y sus dos variantes opuestas, la luz y la noche, entre las cuales se conjugan los seres voladores; la naturaleza como espacio poético de ensoñación y testigo de la destrucción de la infancia recordada; el sistema cromático mediante el cual "colorea" el silencio de sus versos; los espacios artificiales que dan cabida al miedo sin dejarlo salir; los fallidos viajes a través del mar o los cantos desde la otra orilla; la infancia olvidada y el paraíso perdido; el universo pagano de monstruos y seres mitológicos; el cuerpo como unidad desmembrada tras la caída desde el cielo, y la multiplicidad de voces, rostros y máscaras que configuran los dos mundos reunidos en un mismo espejo. 



\section{Bibliografía}

\section{Obras de Alejandra Pizarnik}

\subsection{Primeras ediciones de las obras de A. Pizarnik}

1. Pizarnik, A. (1955). La tierra más ajena. Buenos Aires: Botella al Mar.

2. Pizarnik, A. (1956). La última inocencia. Buenos Aires: Poesía Buenos Aires.

3. Pizarnik, A. (1958). Las aventuras perdidas. Buenos Aires: Altamar.

4. Pizarnik, A. (1962). Árbol de Diana. Buenos Aires: Sur.

5. Pizarnik, A. (1965). Los trabajos y las noches. Buenos Aires: Editorial Sudamericana.

6. Pizarnik, A. (1968). Extracción de la piedra de la locura. Buenos Aires: Editorial Sudamericana.

7. Pizarnik, A. (1969). Nombres y figuras. Barcelona: La Esquina.

8. Pizarnik, A. (1971). El infierno musical. Buenos Aires: Siglo Veintiuno Argentina Editores.

9. Pizarnik, A. (1976). La Condesa Sangrienta. Buenos Aires: López Crespo Editor.

\subsection{Ediciones de la obra de A. Pizarnik}

1. Pizarnik, A. (1975). El deseo de la palabra. Barcelona: Ocnos.

2. Pizarnik, A. (1976). La Condesa Sangrienta. Buenos Aires: López Crespo Editor. 
3. Pizarnik, A. (1982). Textos de sombra y últimos poemas, Buenos Aires: Sudamericana.

4. Pizarnik, A. (1983). Poèmes. Paris: Nadir.

5. Pizarnik, A. (1999). Obras completas. Edición a cargo de Cristina Piña. Buenos Aires: Corregidor.

6. Pizarnik, A. (2001). Poesía Completa. Edición a cargo de Anna Becciú. Barcelona: Lumen.

7. Pizarnik, A. (2002). Prosa Completa, Edición a cargo de Ana Becciú. Barcelona: Lumen.

8. Pizarnik, A. (2003). Antología de la poesía cósmica y tanática de Alejandra Pizarnik. Fredo Arias de la Canal (ed.). México: Frente de Afirmación Hispanista.

9. Pizarnik, A, (2003). Dos letras. Barcelona: March Editor.

10. Pizarnik, A. (2004). La figlia dell'insonnia. Claudio Cinti (ed.). Milán: Crocetti.

11. Pizarnik, A. (2005). Diarios. Barcelona: Lumen.

12. Pizarnik, A. (2007). La extracción de la piedra de locura. Otros poemas. Madrid: Visor.

\section{Libros y artículos sobre Alejandra Pizarnik}

1. Aira, C. (1998). Alejandra Pizarnik. Rosario: Beatriz Viterbo Editora.

2. Aira, C. (2001). Alejandra Pizarnik, Barcelona: Ediciones Omega.

3. Areta, G. (1999). La textura de la oscuridad, El castillo frío de Alejandra Pizarnik. En Areta Marigo, Gema (ed.), Le Corre, Herve (ed. e intr.), Suárez, Modesta (ed. e intr.) y Vives, Daniel (ed. e intr.), Poesía hispanoamericana, Ritmo(s)/métrica(s)/ruptura(s). Madrid: Verbum.

4. Aristeguieta, J. (1972). Alejandra Pizarnik. Genio poético. Árbol de Fuego, 55. Caracas.

5. AA. VV. (1968). Antología consultada de la joven poesía argentina. Buenos Aires: Fabril.

6. Bajarlía, J. (1998). Alejandra Pizarnik. Anatomía de un recuerdo, Buenos Aires: Editorial Almagesto.

7. Beneyto, A. (1983). Alejandra Pizarnik, ocultándose en el lenguaje. Quimera, 34, 23-27.

8. Bordelois, I. (1998). Correspondencia Pizarnik, Buenos Aires: Seix Barral.

9. Bordelois, I. (1963). Alejandra Pizarnik, Árbol de Diana. Sur, 282, 98-100. 
10. Caufield, C. (1992). Entre la poesía y la pintura, elementos surrealistas en Extracción de la piedra de la locura y El infierno musical de Alejandra Pizarnik. Chasqui, 1.XXI, , 3-10.

11. Chirinos, E. (1998). La morada del silencio. Perú: Fondo Editorial de Cultura.

12. Depetris, C. (2005). Aporética de la muerte, estudio crítico sobre Alejandra Pizarnik. Madrid: UAM Ediciones.

13. Foster, W. (1994). The representation of the Body in the Poetry of Alejandra Pizarnik. Hispanic Review, 62,3, 319-347.

14. Fuentes Gómez, J. El surrealismo en Alejandra Pizarnik. Universidad de Murcia en http://www.um.es/tonosdigital/znum11/index.htm

15. Fuentes Gómez, J. Los emblemas de Alejandra Pizarnik. Universidad de Murcia en http://www.um.es/tonosdigital/znum11/index.htm

16. González Lanuza, E. (1969). Alejandra Pizarnik: Extracción de la piedra de la locura. Sur, 319, 107-109.

17. Goldberg F. (1994). Alejandra Pizarnik. "Este espacio que somos". USA: Hispamérica.

18. Graziano, F. (1992). Alejandra Pizarnik. Semblanza. México: Fondo de Cultura Económica.

19. Guibelalde, G. (1998). Aportes para la Extracción de la piedra de la locura: Vida y obra de Alejandra Pizarnik. Ciudad de Córdoba: Ed. Dimas.

20. Haydu S. (1994). Persistencia de la voz poética en Alejandra Pizarnik. Barcelona: Actas del XXIX Congreso del Instituto Internacional de Literatura Iberoamericana, vol. III.

21. Haydu S. (1996). Alejandra Pizarnik: Evolución de un lenguaje poético. Washington: Interamer.

22. Koremblit, B. E. (1991). Todas las que ella era. Buenos Aires: Corregidor.

23. Lasarte, F. (1983) Más allá del surrealismo: la poesía de Alejandra Pizarnik. Pittsburgh: Revista Iberoamericana, 125, octubre-diciembre, 867877.

24. Lentini R. (1999). Leyendo a Alejandra Pizarnik. Tarragona: Igitur.

25. Mackintosh, F. J. (ed.). (2007). Árbol de Alejandra Pizarnik Reassessed. Woodbridge: Tamesis.

26. Mackintosh, F. J. (ed.). (2003). Chilhood in the Works of Silvina Ocampo and Alejandra Pizarnik. Woodbridge: Tamesis.

27. Michal Heidi, G. (1992). Alejandra Pizarnik: "Árbol de Diana". Romanic Review, 83:2, marzo.

28. Moia M. (1972). Con Alejandra Pizarnik: algunas claves. Zona Franca, 16. 
29. Molina, E. (1964). Alejandra Pizarnik: "Árbol de Diana". Cuadernos del Congreso por la Libertad de la Cultura, 90, 89-90.

30. Moratorio, A. (1973). Alejandra Pizarnik: Los pequeños cantos. Árbol de fuego, 59, 26.

31. Moreno, M. (ed.). (1998). Damas de letras: Ocampo, Pizarnik, Shua y otras. Buenos Aires: Libros Perfil.

32. Negroni, M. (2003). El testigo lúcido. La obra de sombra de Alejandra Pizarnik. Rosario: Beatriz Viterbo Editora.

33. Ortega, A. \& Rosano, S. (2005). Mapas e itinerarios en los imaginarios femeninos latinoamericanos. En Imaginarios femeninos en Latinoamérica. Pittsburgh: Revista Iberoamericana.

34. Peri Rossi, C. (1973). Alejandra Pizarnik o la tentación de la muerte. Cuadernos Hispanoamericanos, 273, 584-588.

35. Pezzoni, E. (1965). La poesía como destino. Sur, 297, 101-104.

36. Piña, C. (1999). Alejandra Pizarnik. Buenos Aires: Corregidor, Editorial Planeta Argentina.

37. Piña, C. (1981). La palabra como destino. Buenos Aires: Botella al mar.

38. Piña, C. (1999). Poesía y experiencia del límite: leer a Alejandra Pizarnik. Buenos Aires: Botella al Mar.

39. Rodríguez Francia, A. M. (2003). La disolución en la obra de Alejandra Pizarnik. Buenos Aires: Corregidor.

40. Sucre, G. (1965). Alejandra Pizarnik, La ceremonia poética pura. Zona franca, 23-24.

41. Tembrás Campos, D. (2002). El camino de la mirada (re)creadora en Alejandra Pizarnik. Sobre Un signo en tu sombra. En La literatura hispanoamericana con los cinco sentidos. $V$ Congreso Internacional de la AEELH. A Coruña: Universidade Da Coruña.

42. Venti, P. Alejandra Pizarnik en el contexto argentino. En http://www . ucm.es/info/especulo/numero37/pizaconte.html

43. Venti, P. (2008). Bibliografía completa de Alejandra Pizarnik. Madrid: Del Centro Editores.

44. Venti, P. (2008). La escritura invisible. El discurso autobiográfico en Alejandra Pizarnik. Barcelona: Anthropos.

45. Vila-Matas, E. (2001). La poeta que lloró hasta romperse: Alejandra Pizarnik. El País. Babelia, 3, marzo, s/r número de página.

46. Zonana, V. G. Itinerario del exilio: La poética de Alejandra Pizarnik. Argentina, Universidad de Cuyo, en http://www.scielo.cl/scielo. php?pid=S071809341997000100008\&script=sci_arttext 


\subsection{Bibliografía electrónica sobre Alejandra Pizarnik}

1. www.cibernetic.com/ALE/ale.htm

2. http://patriciaventiliterario.blogspot.com/

3. www.lexia.com.ar/CORTAZAR-HOMENAJE.htm

4. www.literatura.org/Pizarnik/Pizarnik.html

5. www.poeticas.com.ar/Directorio/Poetas_miembros/Alejandra_Piz arnik.html

6. www.sololiteratura.com/pizarnik.htm

7. www.ucm.es/info/especulo/numero23/pizarnik.html 



\section{Referencias Bibliográficas}

\section{Referencias}

1. AA. VV. (1991). El libro de la alquimia. Barcelona: Ciencias ocultas y misterios.

2. Aguirre, R. G. (1979). El movimiento poesía Buenos Aires (1950-1960). Buenos Aires: Ed. Fraterna.

3. Andrés, A. (1969). El 60. Buenos Aires: Editores Dos.

4. Apollinaire, G. (2009). El encantador putrefacto. Las tetas de Tiresias. Buenos Aires: Losada.

5. Baudelaire, CH. (1994). Escritos íntimos. Universidad de Murcia.

6. Breton, A. (2007). Diccionario del surrealismo. Buenos Aires: Losada.

7. Burke, E. (1985). Indagación filosófica sobre el origen de nuestras ideas acerca de los sublime y los bello. Murcia: Colegio Oficial de Aparejadoras y Arquitectos Técnicos de Murcia.

8. Calveyra A. (1997). El hombre del Luxemburgo. Barcelona: Tusquets.

9. Chevalier, J. \& Gheerbrant, A. (2007). Diccionario de los símbolos. Barcelona: Herder.

10. Cirlot, J.E. (2005). Diccionario de símbolos. Madrid: Siruela.

11. Cortázar, J. (2006). Obras Completas. Barcelona: RBA/Instituto Cervantes, Vol. IV.

12. Evtuchenko, E. (1971). Entre la ciudad sí y la ciudad no. Madrid: Alianza.

13. Friedrich, H. (1974). Estructura de la lírica moderna. Barcelona: Seix Barral.

14. Gadamer, H. G. (1998). Estética y hermenéutica. Madrid: Tecnos.

15. Gelman, J. (1994). De palabra. Madrid: Visor.

16. Girri, A. (1978). El ojo. En Obra poética II. Buenos Aires: Corregidor.

17. Lautréamont, C. de (2007). Los cantos de Maldoror. Barcelona: La otra orilla.

18. Piña, C. (1996). Poesía Argentina de Fin de Siglo. Buenos Aires: Vinciguerra. 
19. Salas, H. (1975). Generación poética del 60. Buenos Aires: Ediciones Culturales Argentinas.

20. Salvador, N. (1969). La nueva poesía argentina. Buenos Aires: Nuevos Esquemas.

21. Travadelo, D. A. (2005). La generación poética del 40. Santa Fe: Instituto de Cultura Hispánica.

22. Urondo, F. (1968). Veinte años de poesía argentina (1940-1960). Buenos Aires: Galerna.

23. Vallejo, C. (1986). Obra poética completa. Madrid: Alianza editorial.

24. Vallejo. (1991) Trilce. Madrid: Cátedra.

25. Vera Ocampo, R. (1969). Algunos datos sobre la última poesía argentina. Sur. Buenos Aires.

26. Yurkievich, S. (2002). Fundadores de la nueva poesía latinoamericana. Barcelona: Edhasa. 


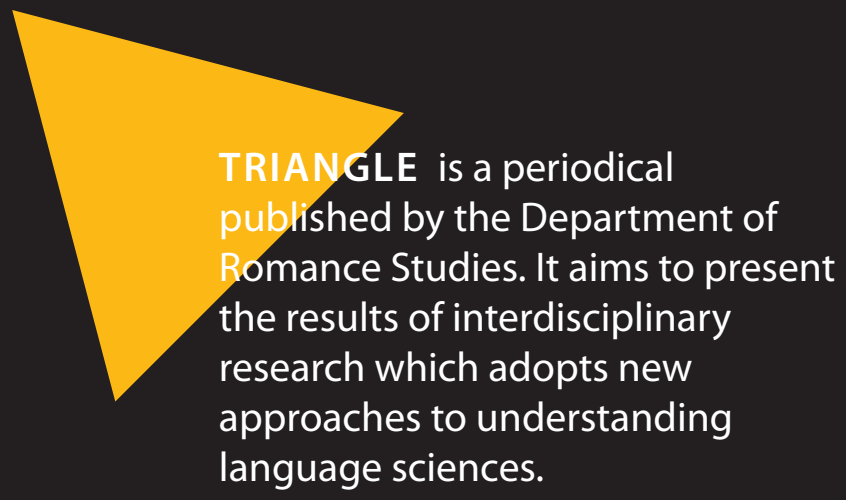

La escritora argentina Alejandra Pizarnik inicia desde la adolescencia un viaje poético que la lleva a construir su propia realidad a través de la palabra, camino que culminará con su personal descenso a los infiernos desde un jardín supuestamente edénico.

Este estudio intenta descifrar las claves de la poesía pizarnikiana, capaz de ahondar en los sentimientos más oscuros de la vida a través de un lenguaje simbólico difícil pero fecundo. 